\title{
METODOLOGIA PARA IDENTIFICAÇÃO, CARACTERIZAÇÃO E REMOÇÃO DE ERROS EM MAPAS DE PRODUTIVIDADE
}

\section{Leonardo Afonso Angeli Menegatti}

\author{
Dissertação apresentada à Escola Superior de \\ Agricultura "Luiz de Queiroz", Universidade de São \\ Paulo, para obtenção do título de Mestre em \\ Agronomia, Área de Concentração: Máquinas \\ Agrícolas.
}

P I R A C I C A B A

Estado de São Paulo - Brasil

Fevereiro - 2002 


\title{
METODOLOGIA PARA IDENTIFICAÇÃO, CARACTERIZAÇÃO E REMOÇÃO DE ERROS EM MAPAS DE PRODUTIVIDADE
}

\section{LeOnARdo Afonso Angeli Menegatti}

Engenheiro Agrônomo

\author{
Orientador: Prof. Dr. José Paulo Molin
}

\author{
Dissertação apresentada à Escola Superior de \\ Agricultura "Luiz de Queiroz", Universidade de São \\ Paulo, para obtenção do título de Mestre em \\ Agronomia, Área de Concentração: Máquinas \\ Agrícolas.
}

P I R A C I C A B A

Estado de São Paulo - Brasil

Fevereiro - 2002 


\title{
Dados Internacionais de Catalogação na Publicação (CIP) DIVISÃO DE BIBLIOTECA E DOCUMENTAÇÃO - ESALQ/USP
}

\author{
Menegatti, Leonardo Afonso Angeli \\ Metodologia para identificação, caracterização e remoção de erros \\ em mapas de produtividade / Leonardo Afonso Angeli Menegatti. - - \\ Piracicaba, 2002. \\ 84 p. : il. \\ Dissertação (mestrado) - - Escola Superior de Agricultura Luiz de \\ Queiroz, 2002. \\ Bibliografia.
}

1. Agric ultura de precisão 2. Mapas 3. Toma da de decisão I. Título

CDD 631.3

"Permitida a cópia total ou parcial deste documento, desde que citada a fonte - $\mathrm{O}$ autor" 


\section{DEDICATÓRIA}

Dedico esta obra a todas as pessoas de bem, que se esforçam para a melhoria do país. Só com trabalho poderemos crescer e desenvolver nossas capacidade de dar condições de vida a todos os brasileiros;

Dedico ainda à minha família, meu pai Antonio Carlos Menegatti e minha mãe Giselda A. Angeli Menegatti, que se esforçaram tanto para meu sucesso e que estão sempre olhando por mim. Que Deus Ihes proteja sempre;

Dedico à minha noiva Adriana, que me apóia e me fortalece quando me sinto fraco;

Dedico ao meu orientador, José Paulo Molin, que soube tão bem passar por cima de meus defeitos e elogiar os progressos, calar às críticas e bendizer bons atos e que tão honestamente conduz seus trabalhos e pesquisas;

Dedico enfim a DEUS Todo Poderoso, para que conduza todos ao bom combate e nos dê forças para vencê-lo;

DEDICO. 


\section{AGRADECIMENTO}

Agradeço a todos os funcionários do Departamento de Engenharia Rural, em especial aos da Mecânica e sempre estiveram prontos a nos ajudar. Gostaria de direcionar um agradecimento aos funcionários Chicão, Afonso, Jukita e Zé Geraldo por estarem sempre dispostos a ajudar.

Agradeço ainda à Fernanda, que sempre disposta ajuda com trâmites burocráticos e abre a porta de entrada para a Mecânica;

Agradeço à Fundação de Amparo à pesquisa do Estado de São Paulo (FAPESP) pelo apoio e financiamento do projeto;

Um agradecimento especial à Fundação ABC, AGCO, Case, John Deere e New Holland pela colaboração na obtenção dos dados. 


\section{SUMÁRIO}

Página

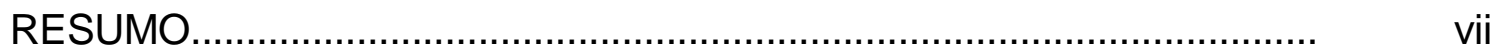

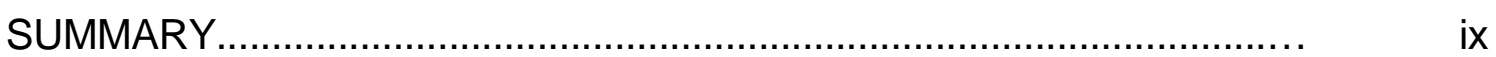

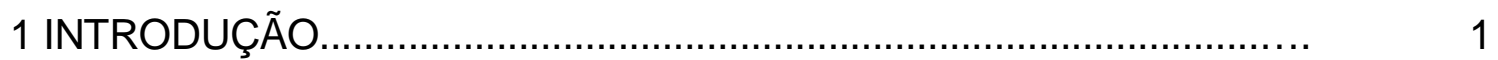

2 REVISÃO DE LITERATURA............................................................

2.1 Obtenção de mapas de produtividade................................................. 3

2.2 Tipos de sensores de fluxo...............................................................

2.3 Fonte de erros em mapas de produtividade ........................................ 9

2.4 Propostas para correção de erros.................................................... 19

3 METODOLOGIA PARA IDENTIFICAÇÃO E CARACTERIZAÇÃO

DE ERROS EM MAPAS DE PRODUTIVIDADE..................................... 22

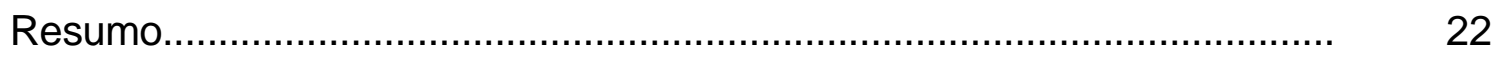

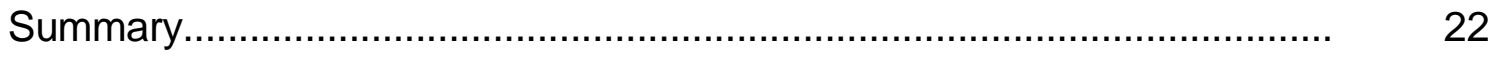

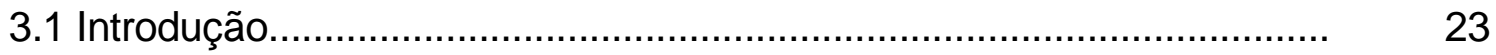

3.2 Revisão de Literatura................................................................... 25

3.3 Material e Métodos............................................................................. 26

3.4 Resultados e Discussão..................................................................... 31

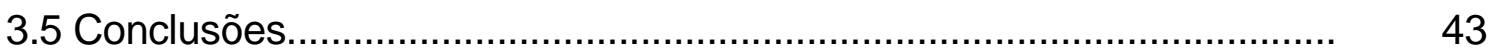

4 REMOÇÃO DE ERROS EM MAPAS DE PRODUTIVIDADE VIA PROCESSO DE FILTRAGEM DE DADOS BRUTOS............................... 44

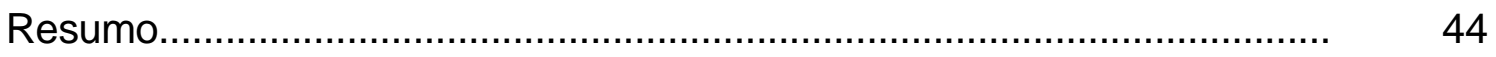

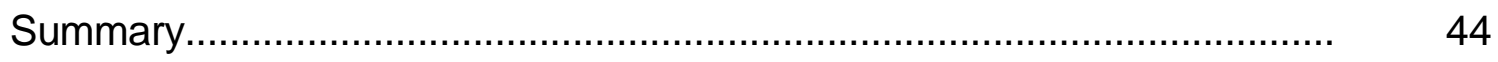

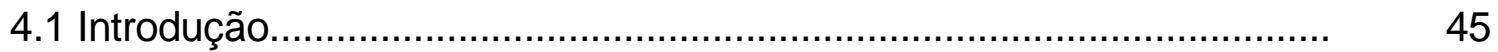

4.2 Revisão de Literatura............................................................................ 46 
4.3 Material e Métodos...................................................................... 50

4.4 Resultados e Discussão.................................................................. 57

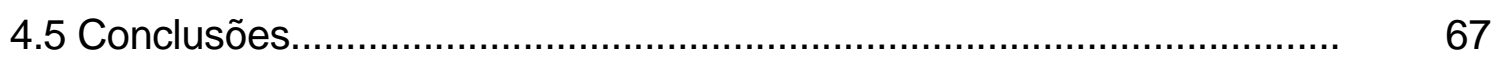

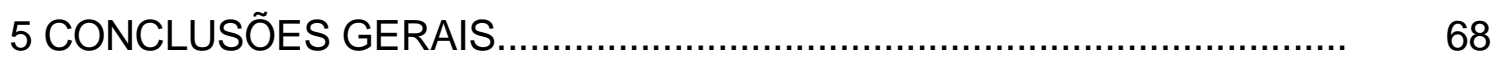

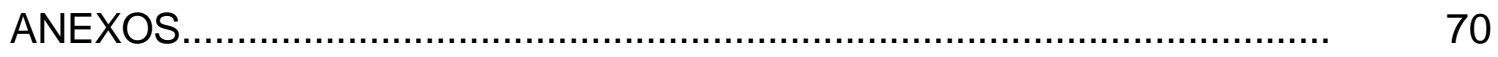

REFERÊNCIAS BIBLIOGRÁFICAS......................................................... 79 


\title{
METODOLOGIA PARA IDENTIFICAÇÃO, CARACTERIZAÇÃO E REMOÇÃO DE ERROS EM MAPAS DE PRODUTIVIDADE
}

\author{
Autor: LEONARDO AFONSO ANGELI MENEGATTI \\ Orientador: Prof. JOSÉ PAULO MOLIN
}

\section{RESUMO}

A agricultura de precisão é um conjunto de tecnologias que prevê o manejo espacializado dos fatores de produção, baseado em informações coletadas e georeferenciadas. O mapa de produtividade é uma informação importante, pois materializa a resposta da cultura a todos os fatores. Diversos monitores de produtividade comerciais estão disponíveis no mercado para a coleta de informações de produtividade de forma bastante adensada. Devido à automação e à alta quantidade de informações, diversos erros ocorrem no processo de coleta e a retirada destes erros é um fator de qualidade da informação. A proposta do trabalho é desenvolver uma rotina de filtragem de dados brutos que elimine erros presentes em mapas de produtividade. Como primeira etapa do desenvolvimento do processo de filtragem, foi realizada a análise e caracterização dos erros presentes em seis mapas de produtividade provenientes de seis diferentes monitores de produtividade comerciais. Erros de posicionamento foram encontrados, representados por pontos fora do talhão, sendo que pequenos erros de posicionamento não podem ser detectados pela 
metodologia desenvolvida. Foram encontrados pontos com produtividade nula, umidade de grãos nula ou ausente e pontos com posição repetida. Pontos coletados com largura de plataforma de corte diferente da total foram considerados erros de medição de área, pois carregam a influência do operador na definição da largura da plataforma de corte efetivamente utilizada. Para a caracterização do erro de intervalo de enchimento foi desenvolvida uma metodologia para identificar o sentido de deslocamento da colhedora, possibilitando assim, a medição do espaço necessário para que o monitor esteja sensível às variações naturais da produtividade. A distância percorrida durante o intervalo de enchimento variou de 0 a $44 \mathrm{~m}$. Foram estabelecidos limites estatísticos para discrepância de valores de produtividade, sendo que foram encontrados pontos com valores de produtividade fora dos limites estabelecidos. Com base nas características de cada tipo de erro, foi desenvolvida uma rotina de filtragem de dados brutos. A rotina consistiu de 7 etapas, sendo que cada uma age sobre determinado tipo de erro de acordo com suas características. Na primeira etapa são retirados do conjunto pontos com erro grosseiro de posicionamento, representados por pontos fora dos limites do talhão. As etapas de número 2 a 5 consistem na retirada de pontos com produtividade nula ou ausente, pontos com largura de plataforma de corte diferente da total, pontos com umidade nula ou ausente e com distância nula entre pontos. A sexta, age sobre pontos gravados durante o intervalo de enchimento, tendo por base a distância referente ao erro e o número de pontos gravados durante tal distância. Foi desenvolvido um algoritmo de busca, identificação e eliminação dos pontos gravados durante 0 intervalo de enchimento. A sétima etapa estabelece limites estatísticos para discrepância de valores de produtividade e elimina pontos fora destes limites. De maneira geral, a filtragem de dados melhorou a modelagem da dependência espacial e elevou a qualidade final dos mapas de produtividade. 


\title{
METHODOLOGY FOR IDENTIFICATION, CHARACTERIZATION AND REMOVAL OF ERRORS ON YIELD MAPS
}

\author{
Author: LEONARDO AFONSO ANGELI MENEGATTI
}

Adviser: Prof. JOSÉ PAULO MOLIN

\section{SUMMARY}

Precision farming is a set of technologies that provide the capacity to manage the yield based on spacialized information. Yield map is an important information as it describes the answer of the crop to the inputs and soil conditions. There are several yield monitors in the market to collect yield information automatically. Due to the automation of the collection, some errors may be collected together with good data, and the elimination of those errors from the data set represents information quality. This work proposes the development a filtering routine of raw data to eliminate errors. The first step is the analysis and characterization of the errors present on data from six different commercial yield monitors. The errors found are positioning errors, represented by points outside the field. Small positioning errors cannot be detected by this methodology. It was found points with null or no yield, null or no grain moisture and points with the same position. Points with swath width different from the total swath width were considered as area measuring errors because they take account the interpretation of the operator about the actual swath width. For the characterization of the combine filling time it was developed a methodology to identify the running direction of the machine, allowing the estimation of the distance required to fill the threshing mechanism of the combine. The distance 
during the filling time was found to be between 0 and $44 \mathrm{~m}$. Yield outlier limits were established, and values over and under the limits were found in the data. Based on the characteristics of each error, a filtering routine was developed. The routine has seven steps, each one acting over different errors. At the first step, positioning errors are eliminated from the data set. The steps from 2 to 5 eliminate points with null or no yield, null or no grain moisture, points with swath width different from the total swath width and points with null distance. The sixth step acts over the filling time error, eliminating all points recorded during the space required for filling up the threshing mechanism of the combine. A search algorithm was developed to identify and eliminate these errors. The seventh step state outlier limits and remove from the data set the values outside of the limits. The filtering process improved the semivariance analysis and the final quality of yield maps. 


\section{INTRODUÇÃO}

Agricultura de Precisão é um sistema de gerenciamento agrícola baseado na variabilidade espacial encontrada nos talhões, visando a otimização do lucro, sustentabilidade e proteção do ambiente.

Esta tecnologia propõe que o tratamento localizado dos pontos do terreno poderá maximizar o uso da terra e de insumos agrícolas, aumentando a produtividade da cultura e diminuindo o custo com insumos. É uma prática que tende a diminuir a toxidez causada pelo excesso de algumas substâncias que são empregadas na produção agrícola, reduzindo assim a pressão no ambiente. A disponibilidade de informação produzida no país a respeito deste assunto ainda é pequena. Neste contexto, é muito importante a busca por informações para a formação das bases brasileiras da agricultura de precisão, para que a tecnologia disponível seja corretamente utilizada.

Com a automação, grande quantidade de dados pode ser coletada com custo relativamente baixo. Os mapas de colheita são produzidos desta forma, automaticamente, com sensores e medidores de produção e de área, integradores destas variáveis. No entanto, esta é uma técnica onde erros podem ser introduzidos como um resultado da automação da coleção de dados, como por exemplo a coleta com a colhedora parada, ou então erros de posicionamento e até mesmo erros de leitura do sensor de fluxo de grãos.

No gerenciamento de propriedades muitas decisões podem ser tomadas tendo por base o mapa de produtividade, como por exemplo o zoneamento de talhões e estratégias de adubação com base na exportação de nutrientes. A presença de erros nos mapas pode induzir a erros estratégicos que podem 
afetar todo o empreendimento. A qualidade da informação em agricultura de precisão é um fator relevante e que deve ser cautelosamente estudado.

Este trabalho visa analisar mapas de produtividade gerados por vários equipamentos comerciais, identificar e caracterizar os erros contidos nos mesmos para obter-se uma rotina de filtragem de dados brutos que possa ser aplicada a todos os mapas produzidos. 


\section{REVISÃO DE LITERATURA}

\subsection{Obtenção de Mapas de Produtividade}

Os primeiros mapas de produtividade foram produzidos a partir do início da década de 90 (Haneklaus et al., 2000). Eram gerados utilizando sistemas de localização locais, com rádios posicionados nas fronteiras do talhão. No início dos anos 90, o sistema GPS se tornou disponível para usuários, possibilitando sua utilização em sistemas de mapeamento de produtividade. Desde então, o mapeamento de produtividade é considerado por muitos pesquisadores como sendo uma parte essencial da agricultura de precisão (Makepeace, 1996). Molin (2000), reforça que o ponto de partida tido por usuários e pesquisadores para se visualizar a variabilidade espacial das lavouras é, sem dúvida, um mapa de produtividade, que materializa a resposta da cultura.

Existem diferentes formas de se abordar a medição do fluxo de sólidos e a tecnologia já está bastante difundida em medições estáticas, como em armazéns ou indústrias processadoras e embaladoras. No final dos anos 80 , surgiram as primeiras tentativas de se medir o fluxo de grãos em colhedoras de cereais. Borgelt (1992) descreveu várias técnicas das quais muitas são utilizadas atualmente na medição de fluxo de sólidos, como medidas volumétricas, fluxo de massa e outros. No início da década de 1990, começaram a ser disponibilizados vários produtos no mercado mundial que se habilitaram a gerar dados para a obtenção de mapas de produtividade (Molin, 2000). Balastreire (1998) e Pecze et al. (1999) consideram que a geração de mapas de produtividade é a fase que apresenta maior facilidade de execução 
devido ao número de pesquisas já realizadas nos países mais desenvolvidos e opções de equipamentos existentes, principalmente para culturas de cereais.

Os monitores coletam informação sobre a produtividade das culturas com freqüência relativamente alta, de 1a 5 segundos. Essa informação é associada com o posicionamento fornecido por um receptor de Global Positioning System (GPS) e então é possível obter-se um mapa de produtividade (Blackmore \& Marshall, 1996). Diversos autores e pesquisadores têm demonstrado fontes potenciais de erros que podem influenciar na acurácia de dados brutos que são coletados durante a colheita e que são utilizados para gerar os mapas de produtividade (Moore, 1998).

\subsection{Tipos de Sensores de Fluxo}

O conjunto responsável pela obtenção dos dados para a geração dos mapas de produtividade compreende uma série de sensores e outros dispositivos. Existem basicamente dois tipos de produtos comerciais para medição da produtividade: a medição da massa diretamente, por meio de células de carga ou potenciômetros, e a medição do volume de grãos que, por meio da sua densidade, é convertido em massa. Molin (2000) sugeriu a classificação dos monitores de produtividade comerciais em dois grupos. $O$ primeiro deles é formado pelos equipamentos das empresas fabricantes das colhedoras. Normalmente, são equipamentos para modelos específicos de máquinas e não são disponibilizados para instalação em máquinas de outros fabricantes. Outro grupo é de fabricantes de equipamentos próprios para instalação em qualquer marca e modelo de colhedoras. Os sensores de fluxo são instalados no elevador de grãos limpos ou na seqüência, antes que o grão entre no tanque graneleiro da máquina.

O monitor de produtividade produzido pela empresa John Deere utiliza uma placa de impacto equipada com potenciômetro. Os grãos são arremessados pelo elevador de grãos limpos contra a placa de impacto, sendo 
que o deslocamento da placa, medido pelo potenciômetro, é proporcional ao fluxo de material que passa pelo sistema. Para um perfeito funcionamento há necessidade do monitoramento da velocidade do elevador, realizado por um sensor específico (Morgan \& Ess, 1997). O sensor desenvolvido pela empresa AgLeader $^{\circledR}$ tem funcionamento semelhante, diferindo apenas por possuir célula de carga ao invés de potenciômetro para medir a força aplicada pela massa contra a placa de impacto. Da mesma forma, tal força é proporcional ao fluxo de grãos.

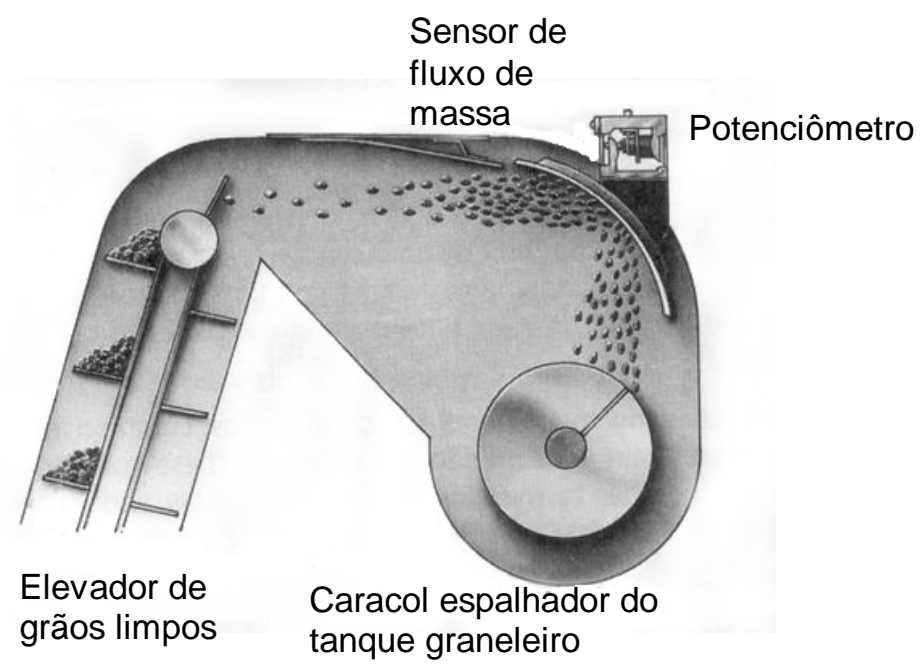

Figura 1 - Sensor de fluxo de grãos com placa de impacto e potenciômetro, que mede o deslocamento da placa, proporcional ao fluxo de grãos, utilizado pela empresa John Deere (Fonte: adaptado de folheto promocional da empresa).

O Sensor desenvolvido pela empresa AGCO é totalmente integrado ao sistema da colhedora. Uma fonte de raios gama é montada da saída do elevador de grãos limpos e gera um fluxo de raios por onde produto colhido passa. Acima do emissor há um receptor que mede a quantidade de raios que chega até ele. Quando não há grãos passando, o receptor detecta o nível máximo de radiação recebido e, quando há fluxo de material passando pelo 
sistema, a radiação absorvida é calculada por diferença em relação à máxima emitida. A radiação é absorvida exponencialmente e depende dos fatores intensidade de radiação, coeficiente de absorção da massa, densidade do material e distância entre a fonte de radiação e o detector. Na colhedora, o coeficiente de absorção da massa e a distância entre a fonte e a detector se mantêm constantes. A intensidade da radiação recebida pelo detector é função apenas da densidade do material que passa pelo sensor (ar e grãos) (Moore, 1998).

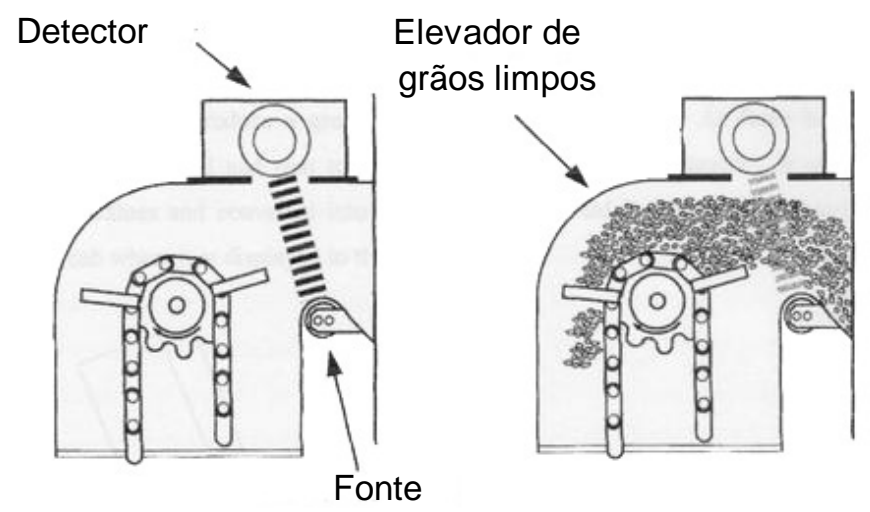

Radioativa

Figura 2 - Sensor de fluxo por detecção de massa da empresa AGCO (Fonte: adaptado de folheto promocional da empresa).

O sensor de fluxo desenvolvido pela empresa Micro Trak pode ser adicionado em qualquer máquina colhedora de cereais. Quando os grãos são arremessados do elevador de grãos limpos para o tanque graneleiro e impactam num garfo instalado nessa região, o fluxo gera um momento de força no garfo, que é medido por uma célula de carga. Também faz parte do sistema um sensor de velocidade do elevador de grãos (Moore, 1998).

A empresa Claas desenvolveu um sensor de produtividade denominado Claydon Yield-o-meter ${ }^{\circledR}$, cujo nome é homenagem ao seu criador, $\mathrm{Mr} \mathrm{J}$. Claydon, e opera de acordo com o princípio volumétrico. O sensor é montado 
entre a saída do elevador de grãos limpos e a rosca sem-fim que os espalha no tanque graneleiro (Figura 4) e é composto por um rotor de pás giratórias de volume conhecido. Um segundo sensor ótico de nível é instalado sobre o rotor para verificar o nível acumulado dos grãos e acionar o rotor de pás quando certo nível é atingido, dando vazão em direção ao tanque graneleiro. O sistema contabiliza o número de rotações do rotor de pás e através da densidade da cultura, obtém-se o fluxo de grãos girando em aproximadamente $30 \%$ do tempo durante colheita normal, indicando que não há perigo de o sistema ficar bloqueado por acúmulo de grãos na saída do elevador (Moore, 1998).

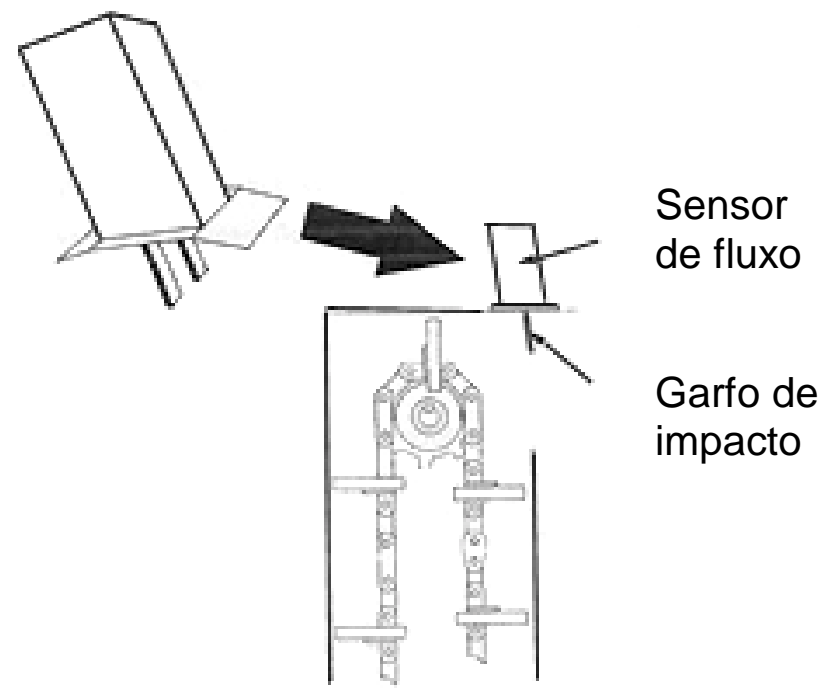

Figura 3 - Sensor de fluxo por detecção de massa do fabricante Micro Track $^{\circledR}$ (Moore, 1998). 

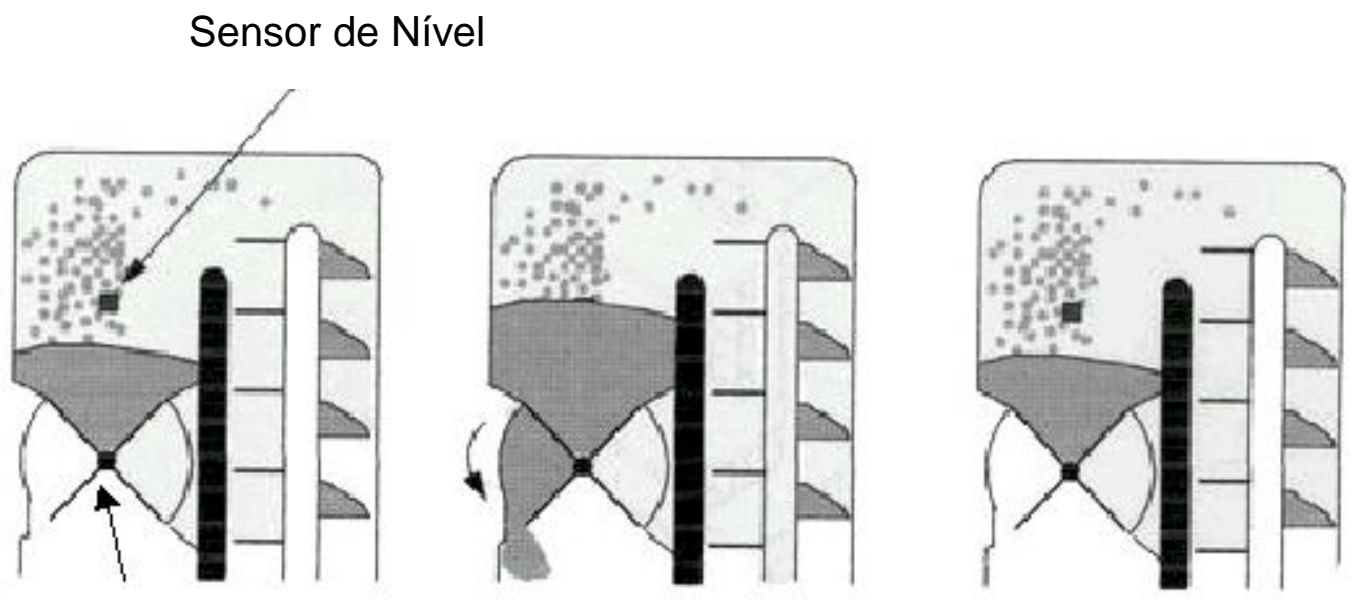

Rotor de Dás

Figura 4 - Sensor de fluxo volumétrico da empresa Class (Moore, 1998).

Outro sensor de fluxo baseado em volume é fabricado pela empresa RDS $^{\circledR}$ Technology. O sistema pode ser adaptado em qualquer colhedora de grãos. Uma fonte de luz infravermelha é montada no alto do elevador de grãos limpos e no lado oposto e alinhado à fonte, é montado um foto sensor, que determina a recepção ou não da luz emitida pela fonte. O conjunto de sensores mede indiretamente a altura da massa de grãos em cada talisca do elevador, através do tempo de corte da luz pela massa. É calculada a seção bidimensional da área de grãos carregados pelas taliscas do elevador, convertida em volume, e em vazão utilizando a informação da densidade do grão (Moore, 1998). 


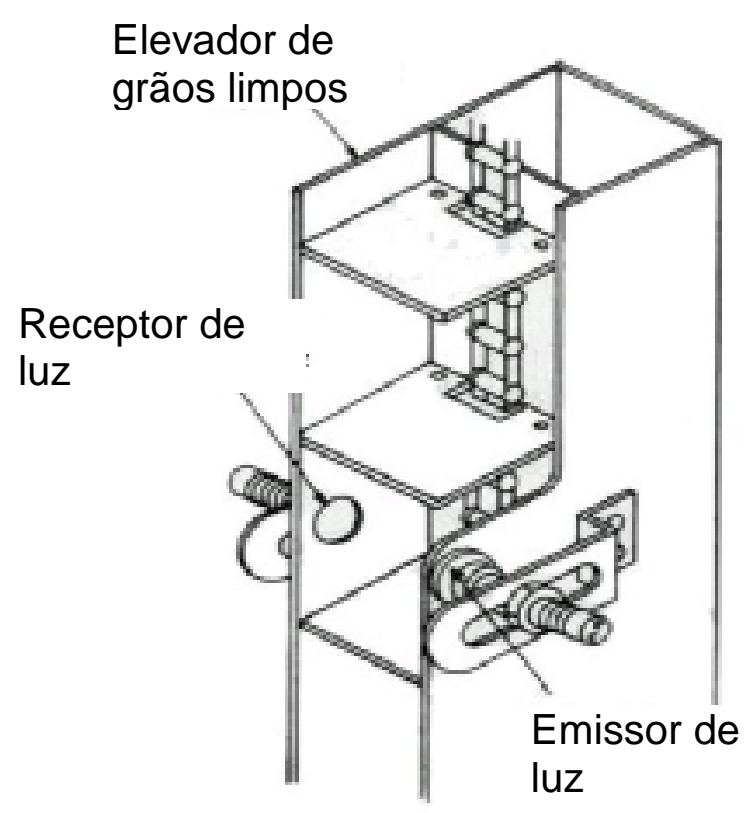

Figura 5 - Sensor de fluxo volumétrico da empresa RDS ${ }^{\circledR}$ Technology (Fonte: Adaptado de folheto promocional da empresa).

\subsection{Fonte de erros em mapas de produtividade}

Existe um considerável número de erros sistemáticos introduzidos num mapa de produtividade. Alguns deles são eliminados pelos programas fornecidos pelos fabricantes e outros não o são. Moore, (1998), trabalhando com dados de seis anos consecutivos de mapeamento de produtividade, identificou os seguintes erros: suavização, calibração de volume, largura incorreta da plataforma e tempo de enchimento da colhedora. Blackmore \& Marshall (1996) citam ainda os erros de posicionamento, devido à recirculação de grãos no mecanismo de trilha e retrilha, perdas de grãos pela colhedora e a acurácia do sensor de fluxo. 
De acordo com Baldwin (1984), citado por Moore (1998), as ocorrências que afetam o crescimento da planta de maneira negativa antes do período de enchimento de grãos, tendem a reduzir a densidade dos grãos e também a produtividade. Diversos fatores podem influenciar o crescimento da planta nesse período, como disponibilidade hídrica e as influências de propriedades físicas e químicas do solo. O autor sugere que crescimento radicular reduzido associado à baixa taxa de absorção de nutrientes tem alta influência na densidade dos grãos. Da mesma forma, fatores biológicos que dependem da genética da cultura interferem na formação excessiva de grãos resultando em muitos grãos chochos, e contribuindo para a redução da densidade da massa.

O sensor de fluxo baseado no princípio de detecção de massa não está sujeito a influências devido à variação da densidade dos grãos. Até o momento, nenhuma compensação automática foi feita para os sistemas que medem a produtividade baseados no princípio volumétrico (Moore, 1998). O mesmo autor, estudando a variabilidade espacial da densidade do grão em 6 talhões durante três anos, encontrou variações de até $16 \%$ na densidade, com média de $9,76 \%$.

Segundo Larscheid (1997), com base em ensaios conduzidos com sensores volumétricos, a densidade do grão deve ser medida pelo menos 5 ou 6 vezes por dia, caso contrário erros sistemáticos ocorrerão, permitindo que os dados se tornem inexatos. Quanto maior o número de recalibrações da densidade de grãos, maior será a acurácia do sistema.

Inevitavelmente, a umidade dos grãos varia no talhão. Se esta variabilidade não for considerada na interpretação dos mapas de produtividade, podem ocorrer erros. O problema é potencializado em condições em que a colheita é iniciada em condições de alta umidade, e no decorrer do processo os grãos secam a uma umidade constante. Tal situação é muito comum e ocorre numa escala muito pequena de tempo, ao longo de um dia. Outra fonte de

\footnotetext{
${ }^{1}$ BALDWIN, J.H. Grain quality: specific weightsUnpublished Cereal communication, n.17. 1994.
} 
variabilidade da umidade é o estágio de maturação das plantas ao longo da lavoura, que pode variar de acordo com a disponibilidade hídrica do solo e também com a exposição à radiação solar. A maioria dos monitores de produtividade comercial possui sensores de umidade dos grãos (Moore, 1998).

A acurácia do sensor de fluxo é outra fonte de erros em mapas de produtividade. Sttot et al.(1993) trabalharam com um monitor de produtividade Claydon Yield-o-meter medindo continuadamente a produtividade numa cultura de milho em 2 talhões de 4 hectares. Compararam o peso fornecido pelo monitor com aquele obtido em um vagão de pesagem e observaram que o erro de totalização foi de $-3,78 \%$ para o talhão 1 e $-3,25 \%$ para o talhão 2 , caracterizando uma situação em que o monitor media consistentemente pesos inferiores aos reais.

Reitz et al.(1996) estudaram os erros potenciais num monitor de produtividade com sensor de fluxo volumétrico RDS ${ }^{\circledR}$ Ceres 2 quando utilizado em declives, ensaiando também outros sensores que visavam melhorar a acurácia dos dados. Um aparato media continuamente a densidade e alimentava automaticamente o sistema para compensar sua variação e um sensor foi adicionado ao monitor para compensar as diferenças na umidade dos grãos. Em ensaios de campo, o erro do sensor foi menor que 3\% durante todo 0 tempo. Entretanto, para erro individual de cada carga da colhedora, esse erro atingiu valores de $5 \%$. Em pequenas parcelas, foram obtidos erros de até $10 \%$. Os autores concluíram que a acurácia do sistema é influenciada pela espécie da cultura, sua umidade e a inclinação horizontal e transversal da colhedora. Pecze, et al. (1999), ensaiando o mesmo monitor em três culturas diferentes, determinaram que a acurácia geral na totalização do monitor foi de 1,02\%.

De acordo com Moore (1998), a empresa RDS Technology comparou a performance de seu monitor com o monitor produzido pela empresa Class (Claydon Yield-o-meter). Para cada tanque graneleiro cheio da máquina foram feitas três diferentes pesagens, sendo o primeiro o peso verdadeiro obtido em 
balança, o segundo o peso estimado e obtido a partir do monitor modelo RDS ${ }^{\circledR}$ Ceres 2 e o terceiro valor obtido a partir do monitor Claydon Yield-o-meter. Concluíram que o monitor é consistentemente acurado dentro do intervalo $\pm 3 \%$ quando comparado com o peso real obtido pela balança. $O$ monitor Class mostrou estimativa consistentemente abaixo do peso real com um erro médio de $-3,6 \%$.

Molin et al. (2000) trabalharam com dados obtidos em duas colheitas num mesmo talhão, comparando pesagens parciais fornecidas pelo monitor RDS ${ }^{\circledR}$ Ceres 2 e o peso real, obtido com balança. Os autores encontraram que no primeiro ano de colheita, o monitor apresentou erro de $-0,50 \%$ e no segundo ano, $-1,03 \%$. Os autores concluíram que alguns fatores de erros são dificilmente controlados, e que os erros encontrados estão dentro de níveis aceitáveis se comparados com valores fornecidos pelos fabricantes e com os obtidos em outros trabalhos.

Auernhammer et al. (1993) compararam o desempenho do monitor de produtividade AGCO (Massey Ferguson) com o monitor da empresa Claas (Claydon Yield-o-meter) em 274 cargas do tanque graneleiro, tendo como referência o peso fornecido por uma balança, em duas safras consecutivas nos anos de 1991 e 1992. Concluíram que a performance geral dos monitores foi bastante similar.

Marcy (1994) coletou dados de 36 colhedoras equipadas com monitor da empresa AgLeader modelo $2000^{\mathrm{TM}}$, e os pesos estimados foram comparados com os pesos reais obtidos a partir de carreta com balança nas culturas de milho e soja. Na cultura do milho foram realizadas 437 comparações, com desvio padrão de $2,7 \%$. Para a cultura da soja foram realizadas 373 medições que resultaram em desvio padrão do erro de $2,5 \%$. O autor concluiu que o erro médio foi de aproximadamente 2,5\%, considerando-o satisfatório.

Birrel et al. (1996) compararam a operação de um sensor volumétrico (Claas) e um sensor de placa de impacto (AgLeader modelo $2000^{\mathrm{TM}}$ ) em 
experimentos de campo. Concluíram o que os sensores de produtividade mostraram alta correlação com os pesos reais. Entretanto, a operação discreta do sensor volumétrico introduziu significativa quantidade de erros no cálculo da produtividade instantânea.

De acordo com Moore (1998), quando comparando o fluxo de massa de grãos acumulado com uma referência obtida a partir de uma balança, a acurácia dos sensores de produtividade geralmente se apresenta dentro do intervalo de $\pm 5 \%$. Em seu trabalho com sensor de produtividade da empresa AGCO, encontrou que os pesos medidos pelo sensor estavam dentro da faixa de erro de $\pm 2 \%$, sendo que apenas uma medida ficou fora desta faixa, inexplicavelmente. Quando comparando medidas instantâneas de fluxo, o autor encontrou que o erro médio durante os ensaios foi de $0,8 \%$ ressaltando, no entanto, que o erro médio pode levar a interpretações errôneas, visto que o mais importante neste caso é a amplitude de variação do erro, cujo valor mínimo foi -22,13\% e o máximo $16,29 \%$.

A habilidade dos monitores em responder rapidamente às mudanças no fluxo de grãos durante a colheita é um fator essencial para a detecção da variabilidade espacial da produtividade e também para garantir a acurácia na determinação da produtividade. De acordo com Doebelin (1966), tempo de resposta é o tempo que um sistema leva para responder a uma entrada com 95\% da intensidade máxima. Segundo Moore (1998), o tempo de resposta é função de um algoritmo suavizador utilizado pelo computador do monitor de produtividade para filtrar os sinais brutos de saída do sensor de fluxo. Este sinal, que tem todas as irregularidades removidas, é utilizado para dar uma indicação acurada do fluxo de grãos. Entretanto, deve haver um compromisso entre a acurácia do sinal de saída do sensor de fluxo e a habilidade do monitor de produtividade de registrar rapidamente as mudanças no fluxo de grãos. Trabalhando com um sensor da empresa AGCO, o autor encontrou uma equação quadrática que descreve o comportamento do tempo de resposta em 
função da alteração no fluxo de grãos. Concluiu que a reação do sensor é mais rápida para degraus maiores de mudança se comparado com o tempo de resposta a degraus menores, sendo o tempo de resposta médio de 13 segundos.

Burks et al. (2001) estudaram a influência da variação dinâmica da taxa de alimentação na acurácia do monitor de produtividade fabricado pela empresa John Deere. Para a realização do ensaio, montaram um elevador de grãos limpos em laboratório com tanques de alimentação e de pesagem, possibilitando assim, a variação controlada do fluxo de grãos. Os autores concluíram que o sensor de produtividade estima com erro de $4 \%$ ou menos a massa acumulada para taxas de alimentação de 4,2 a $16,9 \mathrm{~kg} \cdot \mathrm{s}^{-1}$. O erro médio da medida instantânea de velocidade foi $4,4 \%$.

Blackmore \& Moore (1999) classificaram os erros de posicionamento em dois tipos: aqueles que afetam um pequeno número de pontos e aqueles que são efetivamente deslocamentos de posição. No primeiro tipo citado, encontram-se pontos ocasionais fora da posição em que deveriam estar devido a perda do sinal de correção diferencial por alguns segundos, por exemplo. Também podem ocorrer, no mesmo tipo de erro, pontos fora do talhão que são, evidentemente, erros de GPS. O segundo tipo de erro é representado por deslocamentos na posição devido à diferença de posição entre aquela dada pelo GPS e a da plataforma da colhedora, visto ser pouco prático posicionar a antena do GPS na plataforma. Outra manifestação do mesmo tipo de erro é evidenciada pela superposição de mapas de produtividade produzidos em diferentes anos, que, quando colocados um sobre o outro, evidenciam deslocamentos de fronteiras.

Por outro lado, o sistema GPS está sujeito a diversos erros aleatórios que influenciam na identificação da posição do receptor. Tais erros são descritos por diversos autores (Hurn, 1989; Moore, 1998; Morgan \& Ess, 1997) e podem ser resumidos em erros atribuídos a interferências da ionosfera e troposfera, erros 
do relógio do satélite e do receptor, órbita dos satélites e reflexão ou multicaminhamento. A somatória destes reduzia a acurácia do sistema GPS para cerca de $100 \mathrm{~m}$. De acordo com Morgan \& Ess (1997), a correção diferencial, que pode ser obtida via satélite, por estações locais ou por outras maneiras, elimina os erros do relógio e órbita do satélite e de refração, e reduz consideravelmente os erros do relógio do receptor, da interferência da ionosfera e da troposfera, contribuindo com uma melhoria significativa na qualidade do posicionamento.

Erros de valores extremos de produtividade foram reportados por Juerschik \& Giebel (1999) num conjunto de dados coletados durante a colheita de um talhão. Os autores consideraram que a eliminação de tais pontos deve ser criteriosa por que os dados de produtividade com valores muito altos e muito baixos podem, de fato, ocorrer na natureza.

Em todos os sistemas, a medição da área é necessária para converter o fluxo de grãos $\left(\mathrm{kg} . \mathrm{s}^{-1}\right)$ em produtividade $\left(\mathrm{kg} \cdot \mathrm{m}^{-2}\right)$, e é obtida multiplicando-se a largura da barra de corte da colhedora pela distância percorrida pela máquina num determinado tempo. Tal medição está sujeita a erros tanto na medida da largura de corte real da plataforma quando na distância percorrida pela colhedora. A largura da barra de corte é um valor programado no monitor de produtividade. De acordo com Blackmore \& Moore (1999), na prática, o valor inserido no sistema pode ser $95 \%$ da largura total, assumindo-se assim perda de $5 \%$ devido a deficiências na operação da colhedora. Em plataformas despigadoras, tal erro é minimizado, mas a operação com plataforma parcial pode levar a erros maiores se o monitor não possui um sistema de larguras parciais que corresponda ao número de linhas da plataforma. A maioria dos monitores de produtividade comerciais possui uma chave seletora para indicar ao sistema a utilização de larguras parciais de plataforma. Além disso, os monitores comerciais possuem também uma chave que liga a coleta de dados e a contagem de área quando a plataforma é baixada em início de colheita e 
desliga a coleta quando a plataforma é suspensa nos finais de passadas, para manobras de cabeceira.

De acordo com Moore (1998), é essencial para o operador da colhedora combinar a largura de corte informada ao monitor com a largura efetivamente utilizada. Qualquer desvio ocorrido entre a largura efetiva e a largura informada ao sistema resulta em erros na medição de área e, conseqüentemente, em erros na medição da produtividade da cultura.

Reitz et al.(1996) sugerem que, melhor que confiar na habilidade do operador em manter constante a relação entre largura de corte informada ao sistema e largura de corte efetiva, seria a medição automática e contínua da largura de corte. Para tanto, desenvolveram um sensor ultrassônico instalado nos limites da plataforma de corte. Os autores concluíram que, na prática, a acurácia desse sensor era limitada pelo espaçamento das fileiras e que problemas de acabamento dificultavam a utilização do sensor, que inseria significativos erros na medição da área. Vansichen \& De Baerdemacker (1992) reportaram determinação da largura de corte com acurácia menor que $2 \mathrm{~cm}$ utilizando um transdutor ultrassônico de distância durante colheita de trigo.

Moore (1998) estudou o efeito de passadas com larguras de plataforma parcial em seis talhões durante três anos e encontrou diferenças que variaram de 1,19 a 3,02 t.ha-1 devido à medição incorreta da área comparando-os com os valores vizinhos, obtidos com largura de plataforma total. De acordo com o autor, a diferença entre a largura de corte efetiva e a largura de corte informada ao sistema resultou numa redução da produtividade média em 0,31 t.ha ${ }^{-1}$, correspondendo a uma redução na totalização em 2,4\%.

Moore (1998) destaca que o sensor de velocidade pode inserir erros na medida da área, principalmente no caso dos sensores magnéticos que medem a rotação das rodas de tração. Quando em situações de curva, a velocidade diferencial entre as rodas não é compensada pelo sensor, se instalado em apenas uma das rodas. 
Segundo Moore (1998), o tempo de espera é aquele dispendido entre a ceifa da planta e a passagem do grão pelo sensor de produtividade. O fluxo de grãos medido no sensor de produtividade deve ser correlacionado com a posição da colhedora quando a cultura foi ceifada pela barra de corte. Um tempo incorreto de espera resulta em erros no cálculo da produtividade devido a diferenças de área decorrentes de movimentos acelerados ou retardados da colhedora, resultando em produtividade maiores ou menores que a real. Moore (1998) concluiu que um grande número de fatores afeta o fluxo de grãos da cultura através dos mecanismos ativos da colhedora, tais como o tipo da cultura e a umidade dos grãos. Tais fatores variam espacialmente, dificultando a definição de um único tempo de espera para a máquina.

O tempo de espera incorreto tem ainda o efeito de deslocamento da coordenada dos pontos de produtividade. De acordo com Moore (1998), no momento em que a plataforma ceifa os grãos num determinado ponto, as coordenadas deste ponto são guardadas na memória do sistema por um período equivalente ao tempo de espera sendo que, ao final deste tempo tal posição é associada com a produtividade medida pelo sensor. Quando o tempo de espera é errôneo, ocorre um deslocamento dos pontos em relação à posição real para frente ou para trás, dependendo da direção e sentido do movimento da colhedora e também se o valor inserido no sistema está super ou subdimensionado.

Colvin \& Arslan (2000) observaram que o tempo de espera para colhedoras convencionais é maior que aquele das axiais. As diferenças de funcionamento entre elas, principalmente a ausência de estruturas como o saca-palhas nas colhedoras axiais favorece o fluxo de grãos pelos sistemas até atingir o sensor de fluxo.

Thylén (1997) identificou que o tempo que o fluxo de grãos leva para atingir o sensor de produtividade quando o sistema de trilha da colhedora está vazio (fill time) é diferente se comparado ao tempo para o mesmo processo, 
com o sistema cheio (lag time). A maioria dos sistemas comerciais não faz distinção entre ambos. Moore (1998) estudou tal efeito em mapas de produtividade e sugeriu quatro fases para caracterizar o erro. A primeira fase representa o tempo que a máquina leva para atingir a cultura. A segunda fase é representada pelo tempo entre a máquina atingir a cultura e a primeira leitura do sensor de produtividade. O terceiro estágio é o tempo que a máquina requer para entrar em regime de funcionamento normal, ou seja, é o tempo em que a produtividade registrada pelo sensor de produtividade aumenta rapidamente. A quarta fase se inicia quando a máquina entra em regime de operação normal e assim prossegue por toda a passada de colheita ou até onde ocorra uma interrupção no fluxo de grãos.

Algumas correções tem sido sugeridas para o problema. Thylén et al.(1997), sugerem que os primeiros 40 segundos de cada passada sejam eliminados dos dados para excluir o erro de tempo de enchimento da máquina. Moore (1998), sugere que um tempo de 36 segundos é suficiente para eliminar $100 \%$ do tempo de enchimento. Nolan et al. (1996), relataram que o tempo de enchimento varia entre 10 e 40 segundos. Este tipo de erro é caracterizado nos mapas por baixa produtividade nas cabeceiras do talhão, ou onde a colhedora fizer as manobras.

Erro de mesma natureza, porém em sentido contrário, é o tempo de esvaziamento da colhedora. De acordo com Moore (1998), o tempo de esvaziamento é o período de tempo requerido pela colhedora para esvaziar seus sistemas após a interrupção no corte de grãos pela barra de corte da colhedora. Representa o tempo durante o qual pontos reais de produtividade podem ser gravados uma vez que a barra de corte da colhedora foi levantada. O autor dividiu o erro de tempo de esvaziamento em três estágios. O primeiro estágio corresponde ao tempo existente entre a colhedora deixar a lavoura e o operador suspender a plataforma acima de uma altura predeterminada, o que interrompe a coleta de dados. O segundo estágio representa o tempo entre a 
suspensão da plataforma e a primeira redução no fluxo de grãos registrado pelo sensor de produtividade e o terceiro estágio representa o tempo em que o fluxo de grãos cai rapidamente até que os mecanismos da colhedora se esvaziem de grãos.

\subsection{Propostas para correção de erros}

Desde que mapas de produtividade passaram a ser produzidos, a existência de erros passou a ser notada e pesquisadores passaram a trabalhar com sua correção. Blackmore \& Marshall (1996), propuseram uma técnica chamada Potential mapping, que teoricamente eliminaria o erro na medição de área, sugerindo que os monitores de produtividade gravassem a produtividade em quilogramas, enquanto que a área poderia ser definida posteriormente por um sistema de informações geográficas. Tal técnica foi abandonada por que introduzia significativa quantidade de erros nas bordas do talhão.

Blackmore \& Moore (1999) trabalharam com mapas produtividade produzidos pelo monitor de produtividade da empresa AGCO e desenvolveram uma rotina para remoção de erros. Os autores removeram pontos alocados fora do talhão e corrigiram erros de posição através do deslocamento de todos pontos num sentido e direção, de modo que todos os pontos coerentes estivessem dentro das fronteiras do talhão. A remoção de erros de posição foi feita com base na velocidade pontual calculada da colhedora e na distância entre os pontos. Também removeram os erros de enchimento da colhedora identificando os inícios de passadas da colhedora.

Haneklaus et al. (2000) ressaltaram que a qualidade de um mapa de produtividade depende dos procedimentos adotados em campo, mas que os erros presentes num mapa de produtividade devem ser retirados para interpretação dos dados. Os autores identificaram e trataram os erros de posicionamento e produtividades improváveis, altas ou baixas. Eles identificaram ainda problemas não resolvidos na produção de mapas de 
produtividade como a posição real da produtividade medida que envolve o deslocamento da antena do GPS com relação à plataforma e o tempo de espera necessário para que o grão saia da plataforma e passe pelo sensor de produtividade. Outro problema não resolvido envolve a questão da largura efetiva de corte.

Thylén \& Algerbo (2000) desenvolveram um filtro que remove os erros introduzidos em mapas de produtividade por comparação de cada valor com seus vizinhos, e também estudaram o efeito da aplicação dos filtros em mapas de produtividade. Os filtros aplicados ao conjunto de dados removeram de 10 a $50 \%$ dos pontos coletados pelo monitor. Os autores concluíram que a remoção dos erros pelos filtros aplicados não reduz a variabilidade espacial não explicada pelo semivariograma local ajustado aos dados, mas que é de extrema importância a filtragem dos dados brutos antes que o processo de interpolação seja realizado.

Taylor et al. (2000) avaliaram uma nova técnica chamada Multi-purposing Grid Mapping (MPGM), para a criação de mapas de produtividade. A técnica consiste na determinação de células dentro das quais os pontos de produtividade são analisados. Com base no coeficiente de variação do fluxo de grãos, as células são classificadas como boas ou ruins para a criação final do mapa de produtividade. Os autores concluíram que a técnica é efetiva na criação de mapas de produtividade, especialmente para as condições onde sabe-se da existência de erros da largura de plataforma.

Molin \& Gimenez (2000) desenvolveram um algoritmo para a redução de erros em mapas de produtividade. Os autores trabalharam com os parâmetros média, diferença entre pontos a certa distância na linha e distância entre pontos, sendo o algoritmo programado e aplicado em planilhas eletrônicas. $O$ algoritmo foi aplicado em dois conjuntos de dados exemplo e foram retirados de 21 a $41 \%$ dos pontos, resultando em aumento da produtividade média, redução da variância e do desvio padrão, ressaltando o fato de que a qualidade da 
informação pode ter sido prejudicada em parte pela eliminação de grande quantidade de pontos, mas que ainda assim, a densidade de pontos se manteve elevada. Os autores concluíram que é bastante simples a criação do algoritmo, mas que é necessário conhecimento dos principais tipos de erros presentes nos mapas. A aplicação de tais algoritmos é trabalhosa devido ao tamanho dos arquivos de dados gerados pelos monitores de produtividade existentes no mercado. 


\section{METOdOLOGIA PARA IDENTIFICAÇÃO E CARACTERIZAÇÃO DE ERROS EM MAPAS DE PRODUTIVIDADE}

\section{Resumo}

O mapa de produtividade é considerado por muitos autores o início da agricultura de precisão. A tecnologia para a coleta automatizada de pontos de produtividade proporciona intensa densidade amostral com a inevitável coleta de pontos que contêm erros na medição da produtividade e que podem interferir na análise e tomada de decisão baseada no mapa. Esse trabalho tem por objetivo desenvolver uma metodologia para identificar e caracterizar erros em mapas de produtividade e aplicar essa metodologia para seis diferentes monitores de produtividade comerciais. Nos dados analisados, foram encontrados erros de posicionamento, pontos com produtividade nula ou extrema, ausência de medida de umidade dos grãos, largura de plataforma incorreta devido à interpretação por parte do operador, intervalo de enchimento e de esvaziamento da colhedora e também dados discrepantes. Todos esses erros foram devidamente caracterizados e forneceram bases para a formulação de uma rotina de filtragem de dados brutos.

\section{Summary}

For many researches, yield mapping is the starting of precision farming. Yield monitors measure the yield and collect data in a high frequency, allowing the collection of erroneous data that may interfere in the decision-making based on yield maps. The objective of this work is to develop a methodology to identify and characterize errors on yield maps and apply the methodology to a set of 
data from six different commercial yield monitors. In the data analyzed were found and characterized positioning errors, null or extreme high yield, points with no or null grain moisture, swath width errors due to wrong interpretation of the effective cutting width by the operator, filling and empting time errors and outliers. The characteristic of each error was used to develop a routine for filtering raw yield data.

\subsection{Introdução}

Agricultura de Precisão é um sistema de gerenciamento agrícola baseado na variabilidade espacial encontrada nos talhões, visando a otimização do lucro, sustentabilidade e proteção do ambiente.

Esta tecnologia propõe que o tratamento localizado das diferentes áreas do terreno poderá maximizar o uso da terra e de insumos agrícolas, aumentando a produtividade da cultura e diminuindo o custo com insumos. Essa prática pode colaborar para diminuir a toxidez causada pelo excesso de algumas substâncias que são empregadas na produção agrícola, reduzindo assim a pressão ao ambiente. A disponibilidade de informação produzida no país a respeito deste assunto vem crescendo rapidamente, com grande número de projetos de pesquisa em andamento, estudando a agricultura de precisão.

A coleta automática de dados permite que uma grande quantidade de dados seja obtida, com custo relativamente baixo. Os mapas de produtividade são obtidos automaticamente, com a utilização de sensores especiais. No entanto, esta é uma técnica onde erros podem ser introduzidos como resultado da automação da coleção de dados, como por exemplo, coleta de dados com a colhedora parada, erros de posicionamento e erros de leitura do sensor de fluxo.

O objetivo do trabalho é desenvolver uma metodologia para identificar e caracterizar erros em mapas de produtividade e aplicar essa metodologia para dados de seis diferentes monitores de produtividade comerciais. 


\subsection{Revisão de Literatura}

A agricultura de precisão consiste num número de diferentes tecnologias que são levadas ao campo para permitir um sistema de manejo que considere a variabilidade espacial da produção. De acordo com Cambardella \& Karlen (1999), a Agricultura de Precisão contém três componentes primários: o sistema de posicionamento global (GPS) que fornece a posição onde o equipamento está localizado, mecanismos para controle de aplicação de nutrientes, defensivos agrícolas, água ou outros insumos em tempo real e um banco de dados que fornece a informação necessária para desenvolver as relações causa efeito e as respostas à aplicação de insumos a várias condições especificamente localizadas. Ainda, segundo o mesmo autor, as tecnologias associadas com os componentes eletrônicos estão bastante avançadas se comparadas com o desenvolvimento na interpretação das bases de dados que são necessárias para obter os benefícios econômicos e ambientais que a agricultura de precisão (AP) pode fornecer.

O mapeamento da produtividade é considerado por muitos pesquisadores como sendo uma parte essencial da agricultura de precisão (Makepeace, 1996). Tylén et al. (1997) consideraram que o mapa de produtividade é um dos métodos mais corretos para estimar a heterogeneidade de um campo e Molin (2000) reforça que o ponto de partida tido por usuários e pesquisadores para se visualizar a variabilidade espacial das lavouras é, sem dúvida, tal mapa, que materializa a resposta da cultura. Ele evidencia regiões com alta e baixa produtividade, mas não explica a causa de tal variação, que pode ser por doenças, baixo $\mathrm{pH}$, estresse hídrico e outras e se a causa específica não é determinada, nenhuma resposta ao gerenciamento pode ser obtida (Lark \& Stafford, 1997). Neste contexto, a confiabilidade dos mapas produzidos é essencial para que uma base de dados corretos seja formada para fundamentar a tomada de decisões. Existe um considerável número de erros sistemáticos introduzidos nos mapas e apenas alguns desses erros são eliminados por 
alguns dos programas de mapas (Moore, 1998). Na elaboração de um mapa de produtividade, os dados brutos devem ser cuidadosamente analisados antes da sua produção (Missotten et al., 1996).

Thylén et al. (1997) identificaram diversos erros em mapas de produtividade e os classificaram como relacionados às características físicas da colhedora, do sistema de medição da produtividade, relacionados à variações dentro do talhão, ao operador e devido ao procedimento de obtenção do mapa. Moore (1998), trabalhando com dados de seis anos consecutivos de mapeamento de produtividade, identificou os seguintes erros: suavização, calibração de volume, largura incorreta da plataforma e tempo de enchimento da colhedora. Blackmore \& Marshall (1996) listaram várias fontes de erros em mapas de produtividade. Incluíram aqueles oriundos da retrilha de grãos e das perdas de colheita.

O tempo de enchimento da colhedora é representado pela distância necessária para que o sistema de monitoramento da produtividade fique sensível às variações naturais da produtividade, após o início de gravação dos dados (Moore, 1998). O autor considerou o monitor sensível às variações naturais quando o valor de produtividade atingiu $90 \%$ da produtividade máxima local.

Na produção dos mapas são coletados dados em grande quantidade para a geração de isolinhas de produtividade a partir dos pontos amostrais. De acordo com Haneklaus et al. (2000), a interpolação dos pontos de produtividade numa grade regular é necessária para que diferentes informações possam ser comparadas. Em agricultura de precisão, os métodos mais utilizados para interpolação de dados são os métodos do inverso da distância, vizinho mais próximo e krigagem. No método do inverso da distância, os pontos mais longínquos têm um menor efeito no valor derivado para o nó da grade, que é proporcional ao inverso da distância entre cada ponto e o nó da grade. De acordo com Wollenhaupt (1997), este método não requer modelagem ou estimativas, e é computacionalmente rápido. O método do vizinho mais próximo 
é bastante utilizado para conversão de um conjunto de dados obtidos em espaços regulares em uma grade, ou quando os exemplos tirados em campo se encaixam numa grade, com poucos "buracos" ou pontos perdidos. Quando usado com um pequeno raio de atuação e procura, este método representa muito bem os dados brutos. No entanto, quanto maior o raio, maior a deterioração do coeficiente de determinação e pode chegar ao extremo de não ocorrer interpolação entre pontos (Isaaks, 1989). Ainda segundo o mesmo autor, a krigagem é um dos mais flexíveis e complexos métodos de interpolação e extrapolação de valores para quase todos os tipos de dados. No entanto, com grande quantidade de dados pode se tornar um método bastante demorado. Sua utilização requer o tratamento preliminar dos dados através da geração de um modelo de variabilidade espacial denominado de semivariograma.

\subsection{Material e Métodos}

Os dados de produtividade utilizados para a execução deste estudo são provenientes de seis monitores disponíveis no mercado: RDS ${ }^{\circledR}$ Ceres 2 , RDS ${ }^{\circledR}$ Pro Series 8000, AFS $^{\circledR}$, FieldStar ${ }^{\circledR}$, GreenStar $^{\circledR}$ e New Holland ${ }^{\circledR}$, trabalhando em lavouras com área de 12,6 a 42,2 hectares. O Quadro 1 sintetiza as características dos dados obtidos em cada uma das áreas. A densidade de coleta de dados foi diferente para cada monitor, dependendo da configuração do programa interno de coleta, variando de 214 a 1674 pontos.ha ${ }^{-1}$. Cada monitor de produtividade tem suas próprias características construtivas (Quadro 2), tanto com relação aos sensores envolvidos como também nas diversas formas de gravação dos dados, em código, aberto ou fechado, ou em arquivo texto. Para os arquivos em código fechado há a necessidade de conversão dos arquivos para texto através do programa específico que acompanha cada um dos monitores. 


\begin{tabular}{lcccc}
\hline \multicolumn{1}{c}{ Monitores } & Culturas & $\begin{array}{c}\text { Áreas } \\
\text { (ha) }\end{array}$ & $\begin{array}{c}\text { Número } \\
\text { de pontos } \\
\text { coletados }\end{array}$ & $\begin{array}{c}\text { Densidades } \\
\text { de pontos } \\
\text { (pontos.ha }{ }^{-1} \text { ) }\end{array}$ \\
\hline RDS $^{\circledR}$ Ceres 2 & Milho & 22,0 & 12022 & 546 \\
RDS $^{\circledR}$ Pro Series 8000 & Soja & 22,0 & 9955 & 452 \\
GreenStar $^{\circledR}$ & Milho & 17,7 & 29631 & 1674 \\
FieldStar $^{\circledR}$ & Soja & 78,0 & 19309 & 247 \\
AFS $^{\circledR}$ & Soja & 42,2 & 9047 & 214 \\
New Holland $^{\circledR}$ & Trigo & 12,6 & 8356 & 663 \\
\hline
\end{tabular}

Quadro 1 - Síntese dos dados obtidos com os diferentes monitores e referentes a cada uma das áreas.

\begin{tabular}{|c|c|c|c|c|c|}
\hline \multirow[b]{2}{*}{ Monitor } & \multirow[b]{2}{*}{ Fabricante } & \multirow[b]{2}{*}{$\begin{array}{l}\text { Colhedora } \\
\text { (marca/modelo) }\end{array}$} & \multicolumn{2}{|c|}{ Sensor de Fluxo de Grãos } & \multirow[b]{2}{*}{$\begin{array}{l}\text { Tipo de } \\
\text { arquivo }\end{array}$} \\
\hline & & & $\begin{array}{c}\text { Princípio de } \\
\text { leitura }\end{array}$ & Tipo & \\
\hline $\begin{array}{c}\mathrm{RDS}^{\circledR} \\
\text { Ceres } 2\end{array}$ & $\begin{array}{c}\text { RDS } \\
\text { Technology }\end{array}$ & NH TC 57 & Volumétrico & Ótico & Texto \\
\hline $\begin{array}{c}\text { RDS }^{\circledR} \text { Pro } \\
\text { Series } \\
8000\end{array}$ & $\begin{array}{c}\text { RDS } \\
\text { Technology }\end{array}$ & NH TC 57 & Volumétrico & Ótico & Texto \\
\hline GreenStar $^{\circledR}$ & John Deere & JD 9510 & $\begin{array}{l}\text { Detecção de } \\
\text { massa }\end{array}$ & $\begin{array}{l}\text { Placa de } \\
\text { impacto }\end{array}$ & $\begin{array}{l}\text { Código } \\
\text { fechado }\end{array}$ \\
\hline FieldStar $^{\circledR}$ & AGCO & MF 34 & $\begin{array}{l}\text { Detecção de } \\
\text { massa }\end{array}$ & Radiométrico & $\begin{array}{l}\text { Código } \\
\text { aberto }\end{array}$ \\
\hline $\mathrm{AFS}^{\circledR}$ & AgLeader $^{\circledR}$ & $\begin{array}{l}\text { Case } \\
2166\end{array}$ & $\begin{array}{c}\text { Detecção de } \\
\text { massa }\end{array}$ & $\begin{array}{l}\text { Placa de } \\
\text { impacto }\end{array}$ & $\begin{array}{l}\text { Código } \\
\text { aberto }\end{array}$ \\
\hline $\begin{array}{c}\text { New } \\
\text { Holland } \\
\text { He }\end{array}$ & AgLeader $^{\circledR}$ & NH TC57 & $\begin{array}{l}\text { Detecção de } \\
\text { massa }\end{array}$ & $\begin{array}{l}\text { Placa de } \\
\text { impacto }\end{array}$ & $\begin{array}{l}\text { Código } \\
\text { aberto }\end{array}$ \\
\hline
\end{tabular}

O sistema FieldStar ${ }^{\circledR}$ não possuía sensor de umidade e portanto tal informação não era gravada no arquivo de produtividade. $O$ arquivo gerado pelo sistema também apresentava a largura da plataforma utilizada para a geração da informação. Os monitores $A S^{\circledR}{ }^{\circledR}$ e New Holland ${ }^{\circledR}$ são, na sua essência, os mesmos e produzidos pela empresa AgLeader, sendo que o monitor é personalizado para o fabricante de máquinas que o utiliza em seus produtos. As diferenças de comportamento entre ambos são função da dinâmica interativa 
entre o monitor e a colhedora e dos fatores de configuração do monitor. O monitor GreenStar $^{\circledR}$ é o único em que os dados são gravados em código fechado e que devem ser exportados pelo programa que acompanha o sistema. Os demais arquivos gerados em códigos podem ser abertos por programas especializados, além dos programas que acompanham o monitor.

A metodologia desenvolvida considera erros que podem ser identificados no mapa de produtividade, após a sua produção. Para cada conjunto, o primeiro passo foi uma análise visual do mapa de produtividade num Sistema de Informações Geográficas (SIG), em busca de pontos localizados fora dos talhões (erros grosseiros de posicionamento). Em seguida, os dados foram analisados para se identificar produtividade nula, sendo a ocorrência de tais pontos relatada em forma de porcentagem sobre o total de pontos do arquivo. Também foram identificados erros de leitura do sensor de umidade, representados por valores nulos de umidade ou mínimo aceito pelo sistema, que representa ausência de sinal proveniente do sensor.

Erros na largura de corte na plataforma da colhedora devido à interpretação errônea por parte do operador podem ser identificados no arquivo de colheita. Tais erros possivelmente se manifestam quando a largura parcial efetiva da plataforma é diferente da parcial informada ao sistema e gravada no arquivo. Para sua identificação, buscou-se pontos no arquivo cuja largura de plataforma era diferente daquela informada como teórica e o resultado foi expresso como porcentagem do total de pontos.

As coordenadas geográficas dos pontos para cada arquivo de dados foram convertidas em unidades métricas (UTM) e através do teorema de Pitágoras foi calculada a distância entre pontos consecutivos. Com base na distância, foi possível identificar pontos coletados no mesmo lugar, com distância nula. A ocorrência de distância nula foi considerada erro devido à própria natureza destrutiva da coleta de dados de produtividade. Com base nas coordenadas métricas de cada ponto, foi proposto o índice de deslocamento nas direções norte e leste $(\operatorname{ID}(N) \operatorname{ID}(L))$ (equações 1 e 2), que informam 0 
sentido e direção de deslocamento da colhedora. A Tabela 1 mostra a interpretação do índice com relação à direção e sentido de deslocamento da colhedora.

$$
\begin{aligned}
& I D(N)=X(i)-X(i+1) \\
& I D(L)=Y(j)-Y(j+1)
\end{aligned}
$$

onde:

ID(N) é o índice de deslocamento na direção Norte-Sul;

ID(L) é o índice de deslocamento na direção Leste-Oeste;

$X$ é a coordenada Norte da colhedora;

i é o ponto na direção N-S e sentido considerado;

Y é a coordenada Leste da colhedora;

j é o ponto na direção L-O e sentido considerado.

Tabela 1. Interpretação do Índice de deslocamento da colhedora (ID).

\begin{tabular}{cccc}
\hline & Valor & Direção & Sentido \\
\hline ID $(\mathrm{N})$ & Negativo & $\mathrm{N}-\mathrm{S}$ & Sul->Norte \\
& Positivo & $\mathrm{N}-\mathrm{S}$ & Norte->Sul \\
$\mathrm{ID}(\mathrm{L})$ & Positivo & L-O & Leste->Oeste \\
& Negativo & L-O & Oeste->Leste \\
\hline
\end{tabular}

O sinal do índice de deslocamento foi utilizado como indicador de início e fim de passada de colheita; sempre que ocorria mudança de sinal, nova passada era iniciada. Tendo conhecimento dos inícios e fins de passada, pôdese proceder a caracterização dos erros de intervalo de enchimento e esvaziamento da colhedora. Para a caracterização do intervalo de enchimento, foram escolhidas cinco passadas de colheita aleatórias em cada área e as informações de cada ponto foram colocadas de forma seqüencial, sendo que a distância acumulada foi calculada com base na distância entre pontos. Foi calculada a média da produtividade das passadas escolhidas e os pontos foram localizados em gráficos de dispersão da produtividade em função da distância 
acumulada a partir do início da passada. $O$ intervalo de enchimento foi considerado aquele referente à distância necessária para que o valor da produtividade atingisse $90 \%$ da produtividade máxima local, na média de 5 passadas. As passadas utilizadas para a determinação do intervalo de enchimento foram marcadas no mapa para análise posterior. Procedeu-se então a interpolação dos dados brutos com o intuito de verificar o efeito dos erros no mapa interpolado. O interpolador utilizado foi o método do inverso da distância ao quadrado, com tamanho de célula de $5 \mathrm{~m}$. Com base nas passadas marcadas para determinação das características do intervalo de enchimento, os valores das quadrículas interpoladas correspondentes à mesma posição foram resgatados e comparados com os valores dos pontos e também com a média do talhão. As informações dos valores dos pontos, das quadrículas e da média do talhão foram dispostos num gráfico de dispersão com a distância a partir da borda do talhão no eixo $\mathrm{X}$ e produtividade no eixo $\mathrm{Y}$.

Também foi conduzida análise estatística exploratória dos dados, com cálculo da média, mediana, quartil superior e inferior e variância. Com base nos quartís superior e inferior foram calculados limites superior e inferior para os valores de produtividade, de acordo com metodologia sugerida por Tukey (1977) para a determinação de limites para dados discrepantes. As equações 3 e 4 mostram a forma de cálculo dos limites superior e inferior.

$$
\begin{aligned}
& L S=Q S+1,5 . A I \\
& L I=Q I-1,5 . A I
\end{aligned}
$$

onde:

LS é o limite superior;

LI é o limite inferior;

QS é o quartil superior;

QI é o quartil inferior e

Al é amplitude interquartílica. 
Foram construídos histogramas de distribuição da freqüência de ocorrência de produtividade. Os limites estatísticos superior e inferior foram analisados juntamente com a distribuição de freqüência para a aceitação de tais limites na caracterização de dados discrepantes no conjunto de dados.

\subsection{Resultados e Discussão}

A Tabela 2 resume as características dos erros de posicionamento, valores nulos de produtividade, largura de plataforma de corte diferente da total, distância nula entre pontos e valor nulo para a umidade dos grãos.

Tabela 2. Freqüência de ocorrência de erros encontrados nos arquivos de produtividade de acordo com a metodologia utilizada.

\begin{tabular}{|c|c|c|c|c|c|c|}
\hline \multirow{3}{*}{ Tipos de Erros } & \multicolumn{6}{|c|}{ Monitor em que os arquivos foram gerados } \\
\hline & $\begin{array}{l}\mathrm{RDS}^{\circledR} \\
\text { Ceres } 2\end{array}$ & $\begin{array}{c}\text { RDS }^{\circledR} \text { Pro } \\
\text { Series } \\
8000\end{array}$ & $\begin{array}{l}\text { Field } \\
\text { Star }\end{array}$ & $\begin{array}{l}\text { Green } \\
\text { Star }^{\circledR}\end{array}$ & $\begin{array}{c}\text { New } \\
\text { Holland }^{\circledR}\end{array}$ & $\mathrm{AFS}^{\circledR}$ \\
\hline & \multicolumn{6}{|c|}{ Freqüência de erro (\%) } \\
\hline Erros de posicionamento & 0,00 & 0,07 & 0,00 & 0,00 & 6,30 & 0,00 \\
\hline Produtividade nula & 0,33 & 4,60 & 0,00 & 2,34 & 1,83 & 0,34 \\
\hline Largura de plataforma & 4,10 & 10,80 & ND* & 5,60 & 4,30 & 1,29 \\
\hline $\begin{array}{l}\text { Distância nula entre } \\
\text { pontos }\end{array}$ & 0,00 & 0,00 & 0,08 & 11,48 & 0,07 & 0,00 \\
\hline Umidade nula & 9,50 & 9,30 & $N D^{*}$ & 3,80 & 1,40 & 1,06 \\
\hline
\end{tabular}

A identificação de erros do sensor de umidade pode ser falha, pois identifica apenas casos em que não houve leitura de umidade e, no entanto, houve leitura do sensor de fluxo, tendo como resultado um ponto com umidade nula no arquivo. Não são identificados erros sistemáticos ou aleatórios na leitura do sensor, apenas falhas na leitura. No arquivo de dados obtido com o monitor de produtividade RDS $^{\circledR}$ Ceres 2, a ocorrência de valores nulos de umidade em $9,50 \%$ dos pontos, está associada à ocorrência de valores de produtividade de 9999,9 t.ha ${ }^{-1}$. 
A ocorrência de valores 9999,99 t.ha $^{-1}$ no arquivo obtido com o monitor RDS $^{\circledR}$ Ceres 2 provavelmente está associada à ocorrência de leituras no sensor de fluxo com a plataforma levantada, situação que poderia ser interpretada como produção em área nula. A produtividade é o resultado da derivação da produção em relação à área e, sendo esta nula, a produtividade tende ao infinito, interpretado pelo monitor como 9999,99 t.ha ${ }^{-1}$. Pode haver outros motivos para a ocorrência de tais dados no arquivo, visto que o algoritmo de leitura do monitor é desconhecido e não foi analisado durante o trabalho.

Nos dados obtidos com o monitor RDS ${ }^{\circledR}$ Pro Series 8000 , a ocorrência de produtividades nulas está associada, de certa forma, à ocorrência de umidade nula, mas a totalidade dos pontos que possuem largura de plataforma nula possuem também produtividade com mesmo valor. Nos dados obtidos com o monitor FieldStar ${ }^{\circledR}$, a análise inicial identificou pequena quantidade de erros, com apenas algumas ocorrências de distâncias nulas entre pontos.

A existência de distância nula entre pontos nos dados obtidos pelo monitor GreenStar $^{\circledR}$ está associada também à produtividade nula ou simplesmente ausente, e a valores nulos de umidade. Parte dos pontos que apresentaram distância nula entre si possuíam também produtividades improváveis e muito elevadas. Os erros apresentados pelos dados obtidos com o monitor New Holland $^{\circledR}$ mostraram-se independentes entre si, sendo que o erro de maior ocorrência foi o de posicionamento, representado por um grupo de pontos localizados fora do talhão. Os erros devido à imprecisão do GPS não são identificáveis por essa metodologia. A mesma ausência de relação entre os erros é mostrada pelos dados obtidos com o monitor $\mathrm{AFS}^{\circledR}$.

Especificamente com relação ao monitor $\operatorname{GreenStar}^{\circledR}$, a alta freqüência de ocorrência de pontos com distância nula entre si é provavelmente devida à alta taxa de coleta de pontos associada a pequenos erros de posicionamento e também à baixa velocidade da operação colheita. Muitos pontos são coletados num intervalo curto de tempo, intervalo provavelmente insuficiente para que o 
GPS detecte a mudança de posição da colhedora e informe ao sistema a nova posição diferente da anterior. Por outro lado, como a velocidade da colheita é baixa, a distância percorrida pela colhedora dentro do intervalo de coleta de dados também é pequena e está dentro do círculo de erro provável da maioria dos GPSs utilizados em agricultura de precisão, possibilitando assim que a nova posição seja erroneamente equivalente a anterior.

O resultado da aplicação do índice de deslocamento em um dos arquivos de produtividade pode ser visto na Figura 1. Tal índice permite a identificação exata do percurso da colhedora, o início e final de cada passada. Porém pode ser aplicado apenas quando há uma única direção predominante de colheita, seja Norte-Sul, Leste-Oeste ou direções intermediárias. Quando as passadas de colheita possuem mais de um sentido, como por exemplo, em curvas acentuadas, a metodologia mostra-se limitada na identificação do sentido de deslocamento.

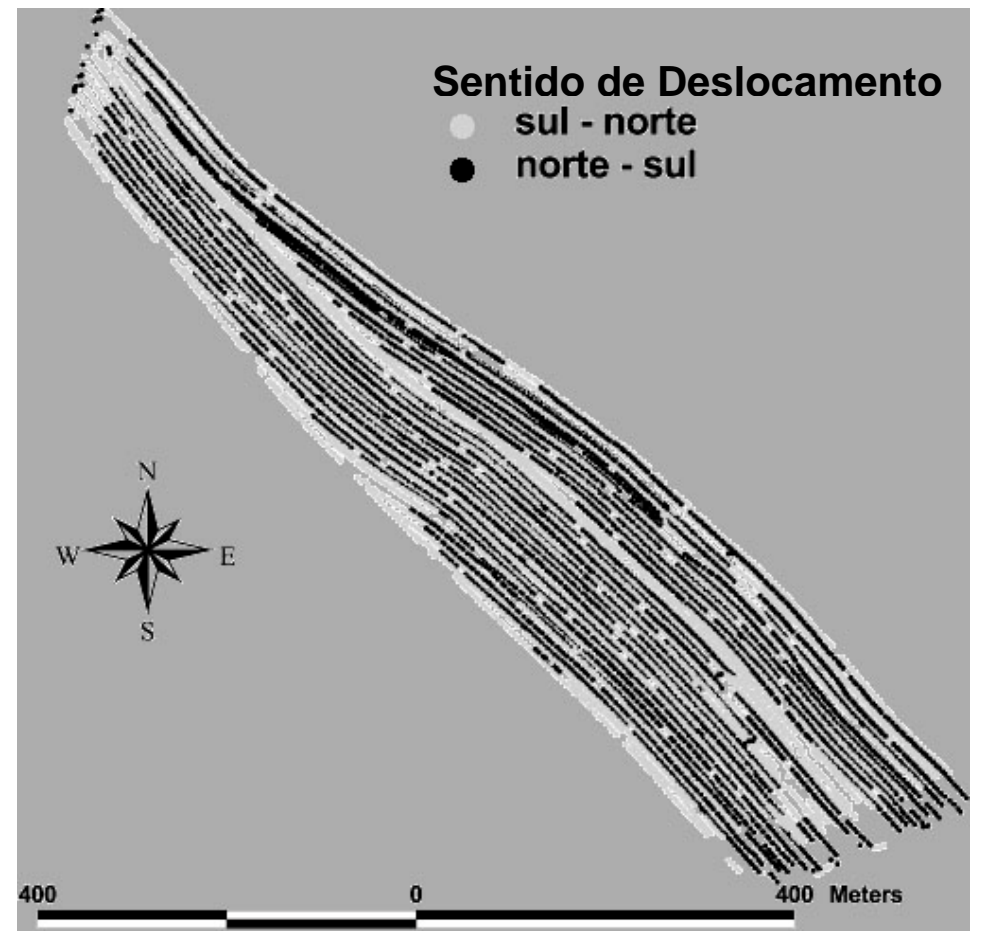

Figura 1 - Resultado da aplicação do método de determinação do sentido de deslocamento nos dados obtidos com o monitor RDS ${ }^{\circledR}$ Ceres 2 . 
A Figura 2 mostra a produtividade das cinco passadas da colhedora escolhidas aleatoriamente dentro dos dados obtidos com cada um dos monitores em função da distância acumulada a partir da borda do talhão. Também apresenta a produtividade média das cinco passadas em função da distância acumulada, a partir da qual foi determinado o intervalo de enchimento.
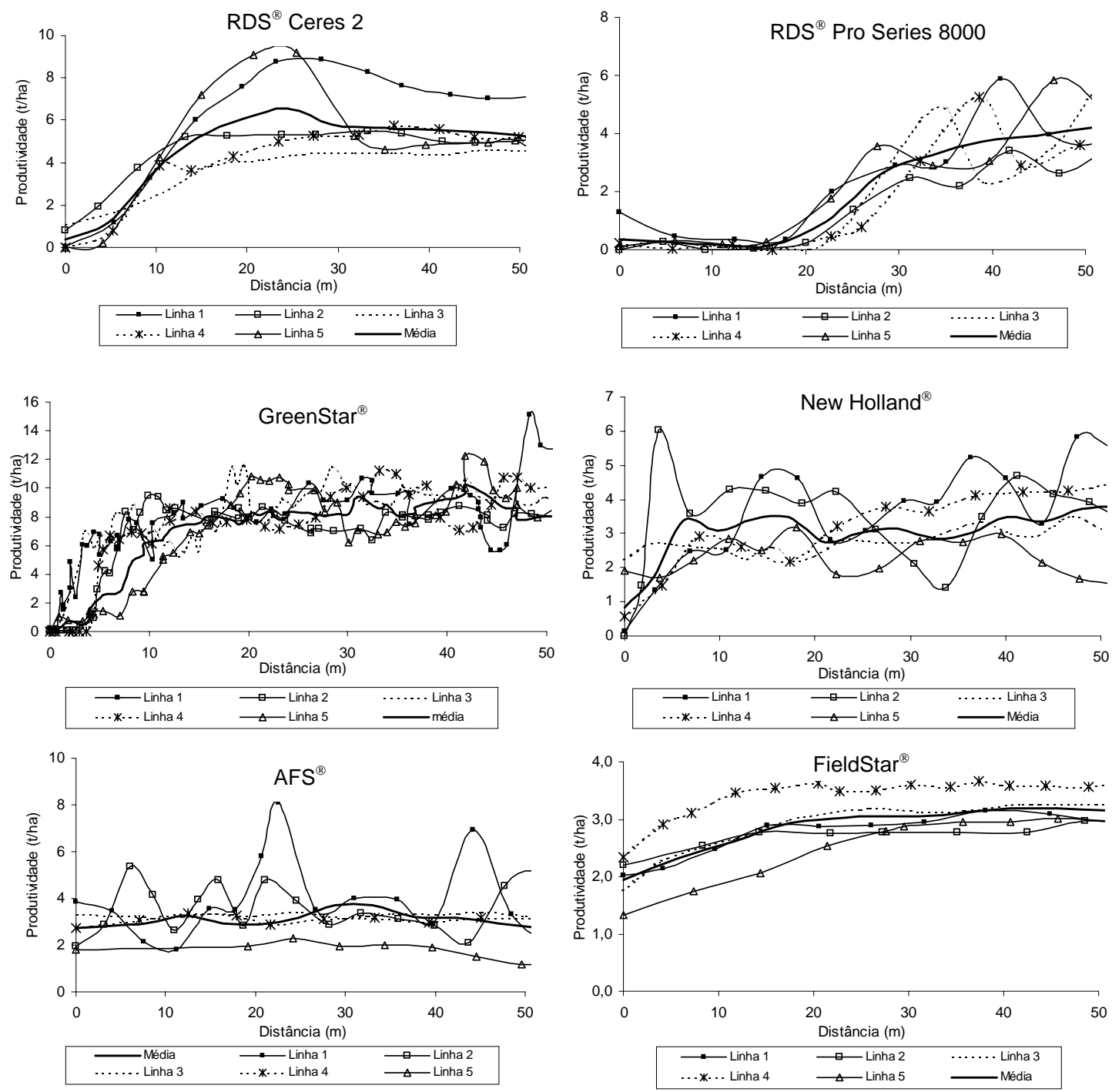

Figura 2 - Efeito do intervalo de enchimento na coleta de dados de produtividade para cada arquivo analisado proveniente dos diferentes monitores. 
Os dados obtidos com o monitor RDS ${ }^{\circledR}$ Ceres 2 apresentaram intervalo de enchimento correspondente a 19,58 m, enquanto que os dados obtidos com o monitor RDS ${ }^{\circledR}$ Pro Series 8000 apresentaram intervalo de enchimento de $44 \mathrm{~m}$, sendo que foram necessários $20 \mathrm{~m}$ de percurso para que os valores lidos pelo monitor apresentassem $20 \%$ da produtividade máxima local. Embora ambos utilizem o mesmo sensor de fluxo de grãos, o comportamento das linhas de produtividade em função da distância acumulada é bastante diferenciado, com tendência suave no caso dos dados obtidos com o monitor RDS ${ }^{\circledR}$ Ceres 2 e com tendência oscilante para os dados obtidos com o monitor RDS ${ }^{\circledR}$ Pro Series 8000. Tais diferenças são função do programa interno de coleta de dados, que insere maior suavização nos dados do primeiro com relação ao segundo. Os dados obtidos com o monitor GreenStar ${ }^{\circledR}$ apresentaram intervalo de enchimento de $14,11 \mathrm{~m}$, com a particularidade da alta freqüência de coleta de pontos (Quadro 1). Muito provavelmente, devido a esse fato, ocorrem pontos de alta produtividade muito próximos a outros com baixa produtividade, estando as linhas de produtividade mais agrupadas, com menor dispersão entre os pontos. Já para os dados obtidos com o monitor New Holland ${ }^{\circledR}$, o intervalo de enchimento foi equivalente a 13,53 m, de acordo com o critério adotado. Porém, considerando que, com $89 \%$ da produtividade máxima (ao invés dos $90 \%$ propostos) o monitor está sensível às variações naturais da cultura, o intervalo de enchimento cai para $6,20 \mathrm{~m}$. Os dados obtidos com o monitor $\mathrm{AFS}^{\circledR}$ não apresentaram erros devido ao intervalo de enchimento da colhedora e os dados obtidos com o monitor FieldStar ${ }^{\circledR}$ apresentaram distância de 17,52 m referente ao intervalo de enchimento, apesar de não ter seu início com produtividade nula. Para os dados coletados com esse monitor, as passadas da colhedora analisadas apresentaram pontos bastante uniformes, com grande suavização dentro de uma mesma passada.

O efeito do intervalo de enchimento obtido no mapa após a interpolação pode ser observado na Figura 3. De maneira geral, todos os monitores que 
apresentaram erros de intervalo de enchimento o transferiram para o mapa de dados interpolados. Por outro lado, o interpolador produziu um efeito suavizador nos dados, aproximando a região sob efeito do intervalo de enchimento da média do talhão.
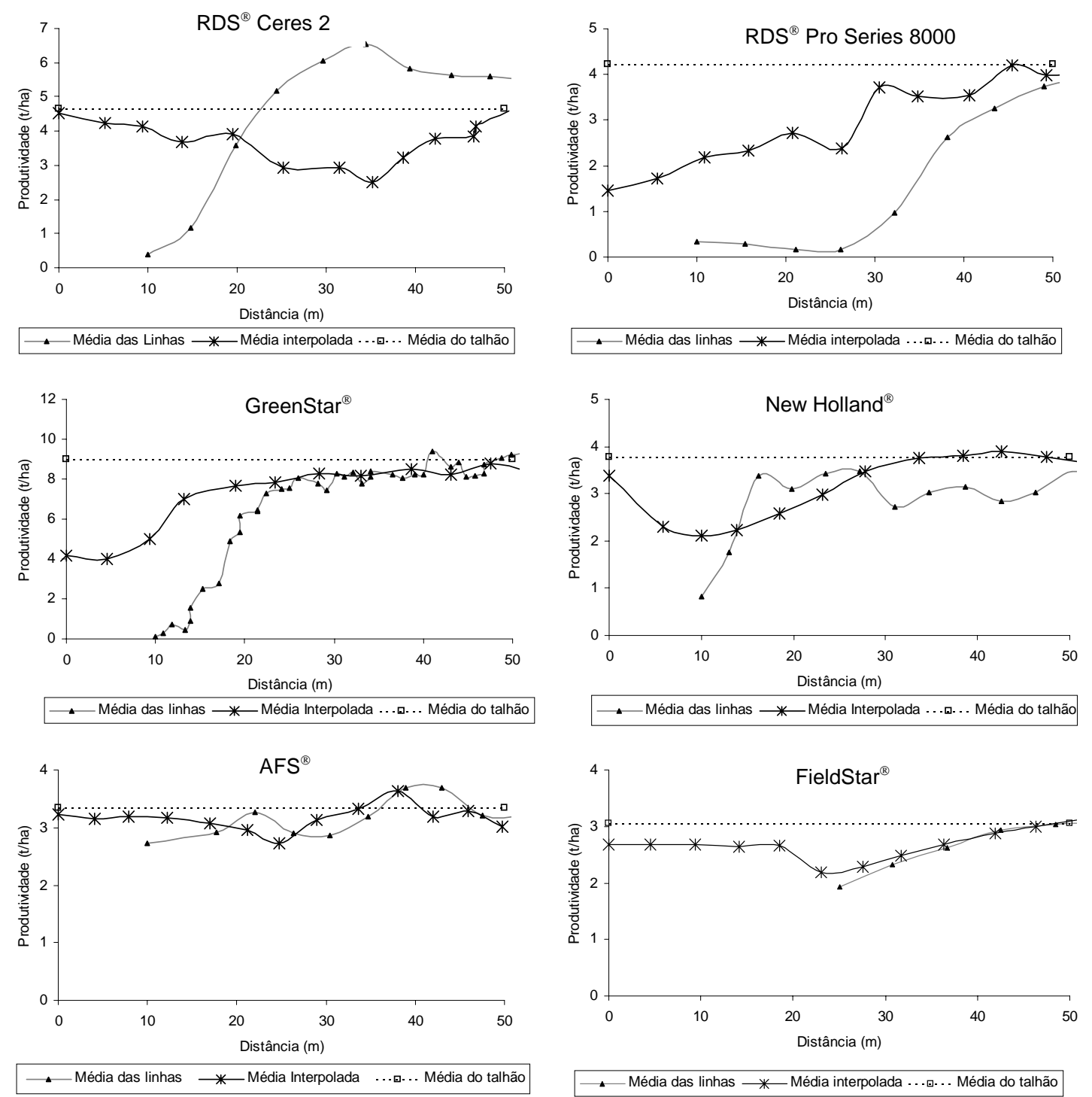

Figura 3 - Efeito do intervalo de enchimento no mapa de dados interpolados para os arquivos analisados obtidos pelos diferentes monitores de produtividade. 
O interpolador produziu efeitos diferentes nos dados dos monitores, aproximando mais os valores em relação à média para os dados obtidos com o monitor $\mathrm{RDS}^{\circledR}$ Ceres 2 em relação aos outros. $\mathrm{O}$ monitor $A F S^{\circledR}$, por não apresentar erros de intervalo de enchimento, apresentou resultados muito semelhantes para os dados interpolados e para a média das passadas. Mesmo com intervalo de enchimento de $44 \mathrm{~m}$, o interpolador promoveu grande suavização nos dados obtidos pelo monitor $\operatorname{RDS}^{\circledR}$ Pro Series 8000 , diminuindo a diferença existente entre a média do talhão e a média das passadas (Figura 3). 

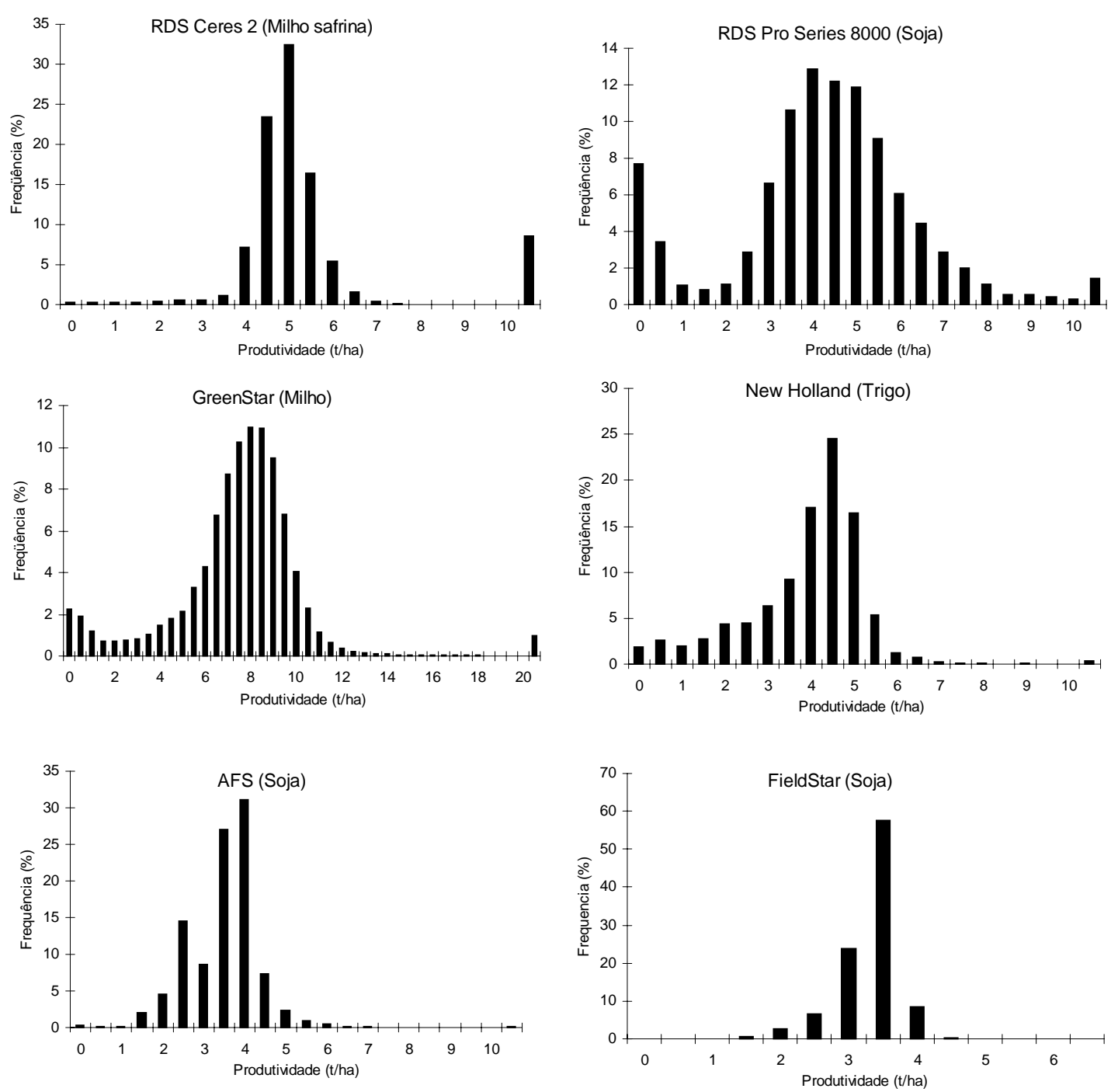

Figura 4 - Histogramas de distribuição da freqüência de ocorrência de produtividade para os arquivos analisados obtidos pelos diferentes monitores de produtividade.

Não há nada que assegure a normalidade da distribuição de freqüência dos mapas de produtividade, e tampouco deve ser assim. O histograma de distribuição pode mostrar informações importantes no entendimento do mapa de produtividade. O histograma apresentado na Figura 4, que representa os dados obtidos com o monitor AFS $^{\circledR}$, mostra claramente dois padrões de distribuição, com alta ocorrência de alta produtividade para soja (entre 3,5 e 4 
t.ha $^{-1}$ ) e uma segunda parte do talhão, com produtividade menor e alta freqüência de ocorrência $\left(2,5\right.$ t.ha $\left.^{-1}\right)$. Valores nulos de produtividade certamente são erros de medição.

Os pontos com baixa produtividade e baixa ocorrência provavelmente contêm os erros de intervalo de enchimento, produtividade nula, erros de medição do sensor de umidade, mas também podem conter pontos que representam fielmente a produtividade da cultura. Visualmente, pode-se verificar onde ocorre a mudança de comportamento da freqüência de ocorrência dos pontos de produtividade (Figura 4), mas a aplicação da metodologia proposta por Tukey (1977) forneceu bases para a classificação dos dados supostamente errôneos em discrepantes. A Tabela 3 mostra a análise estatística descritiva e a análise de dados discrepantes. 
Tabela 3. Análise estatística descritiva e de dados discrepantes para os arquivos de dados estudados.

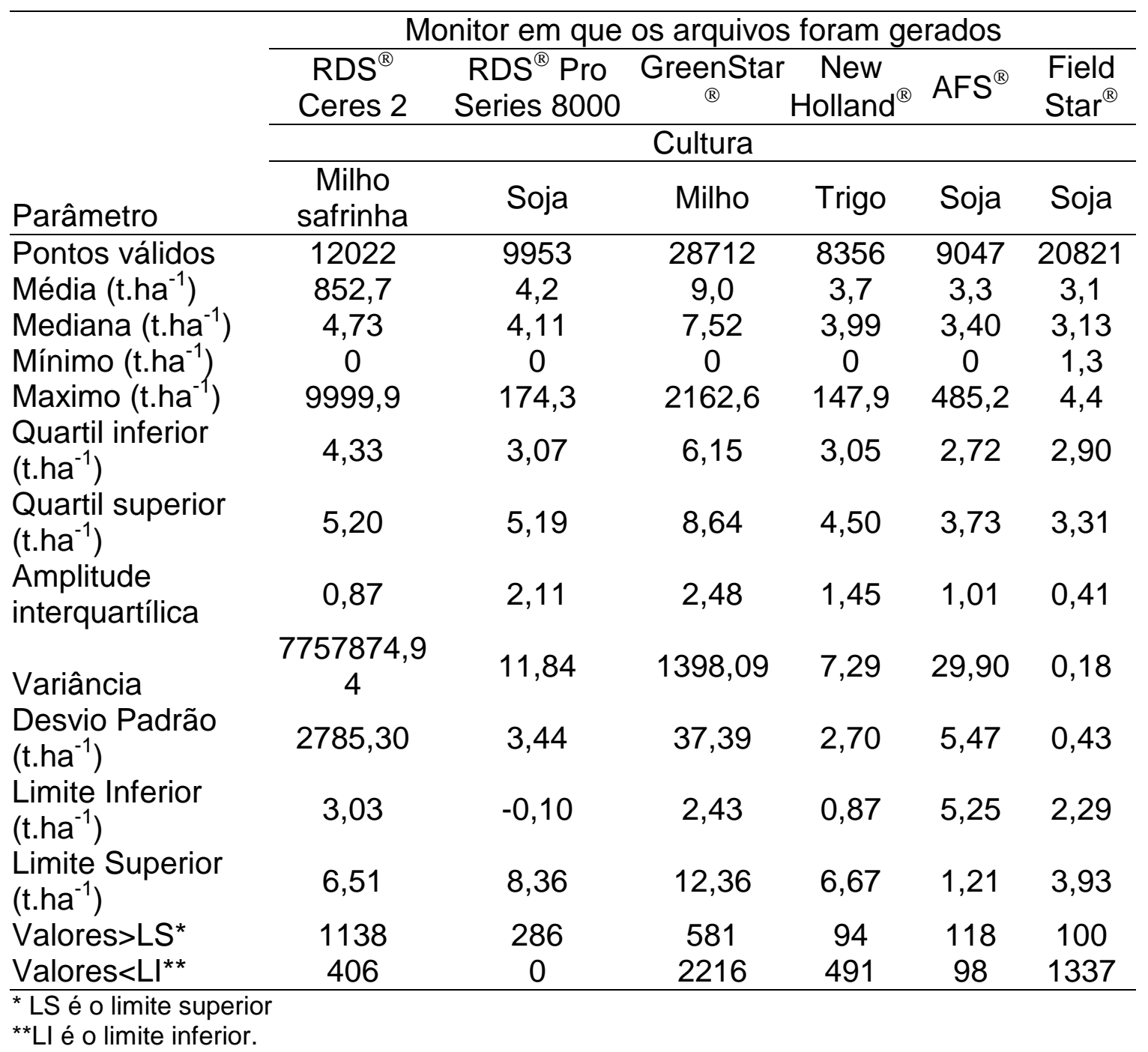

Pela análise de dados discrepantes, o limite inferior estatístico para os dados obtidos com o monitor Ceres 2 foi calculado em 3,03 t.ha ${ }^{-1}$ e coincide no histograma com a região onde ocorre pequena ocorrência de pontos de produtividade, resultando em 406 pontos abaixo do limite inferior. O limite superior foi de 6,51 t.ha-1, resultando em 1138 pontos considerados discrepantes, coincidindo com a diminuição na ocorrência de pontos de produtividade. Observa-se que há grande discrepância entre o valor da média e da mediana, em função da alta freqüência de ocorrência de valores 9999,9 
t.ha ${ }^{-1}$. Já para os dados obtidos com o monitor RDS ${ }^{\circledR}$ Pro Series 8000 , o limite inferior foi negativo, resultando que nenhum ponto foi selecionado abaixo desse limite. Este resultado foi obtido devido à alta ocorrência de valores nulos de produtividade. Apesar da mediana ser uma medida de posição mais robusta que a média, alta freqüência de ocorrência pode afetar os resultados (Tukey, 1977). No processo de filtragem, por ocasião do cálculo dos limites, os dados já terão passado por filtros que eliminarão a interferência de produtividade nula no cálculo dos limites. Com relação ao limite superior, de 8,36 t.ha $^{-1}$, há 286 pontos maiores, que foram considerados discrepantes.

A média e mediana para os dados obtidos com o monitor GreenStar $^{\circledR}$ também apresentaram distanciamento, sendo a média de 9,00 e a mediana de 7,52 t.ha ${ }^{-1}$. O limite inferior para valores discrepantes foi de 2,43 t.ha ${ }^{-1}$ ocorrendo 2216 pontos menores que o limite estabelecido. O limite inferior calculado coincide com a alteração no padrão da distribuição. Abaixo deste limite estão todos pontos cujos valores de produtividade são nulos, e também os pontos cuja umidade é nula. O limite superior para os dados foi de 12,36 t.ha ${ }^{-1}$, com a ocorrência de 581 pontos acima do limite e foram considerados como discrepantes. Os dados obtidos com o monitor New Holland ${ }^{\circledR}$ apresentaram relativa simetria, com média bastante próxima à mediana (Tabela 3 ). $\mathrm{O}$ limite superior para classificação de dados como discrepantes foi calculado com produtividade igual a 6,67 tha ${ }^{-1}$, havendo ocorrência de 94 pontos com valores superiores ao limite. No outro extremo da distribuição, há 491 pontos menores que o limite inferior, de 0,87 t.ha $^{-1}$. A localização dos limites superior e inferior no gráfico de distribuição de freqüência de produtividades coincide com os pontos onde visualmente pode-se verificar alteração no padrão de distribuição, como pode ser observado com o limite inferior, que considera como discrepantes todos dados referentes a distribuição nas classes de 0 a 1 t.ha ${ }^{-1}$. No entanto, podem ocorrer pontos reais com produtividade baixa que estarão sendo classificados como discrepantes por esta análise. Por outro lado, pode- 
se considerar que a quantidade de pontos reais classificados como discrepantes será pequena, devido à própria metodologia utilizada.

Com média de 3,30 e mediana de 3,40 t.ha' ${ }^{-1}$, os dados obtidos com o monitor $\mathrm{AFS}^{\circledR}$ apresentaram seus limites superior e inferior calculados em 5,25 e 1,21 t.ha ${ }^{-1}$ (Tabela 3), resultando em 118 pontos com valores maiores que o limite superior e 98 pontos menores que o limite inferior.

Os dados obtidos com o monitor FieldStar ${ }^{\circledR}$ apresentaram produtividade mínima de 1,30 t.ha ${ }^{-1}$, indicando que, provavelmente há, no programa interno de coleta de dados, um filtro que impede a coleta de dados nulos. Os valores da média e mediana estão muito próximos $\left(3,10\right.$ e 3,13 t.ha ${ }^{-1}$ respectivamente) indicando simetria nos dados, confirmada pelo coeficiente de assimetria. $O$ limite inferior calculado para os dados foi de 2,29 t.ha ${ }^{-1}$ e o limite superior foi de 3,93 t.ha ${ }^{-1}$, sendo que a amplitude do limite é de 1,64 t.ha ${ }^{-1}$. A pequena ampl7itude do limite pode ser atribuída à grande suavização promovida pelo programa interno de coleta de dados do monitor ou à pequena variabilidade espacial da produtividade nos dados analisados. Tanto uma como outra hipótese leva à concentração de valores em torno da média, que resultou em amplitude interquartílica de 0,41 t.ha ${ }^{-1}$.

Foram encontrados erros ou pontos discrepantes em todos os conjuntos de dados analisados. Os dados obtidos com os monitores RDS ${ }^{\circledR}$ Ceres 2, RDS $^{\circledR}$ Pro Series 8000 e GreenStar $^{\circledR}$ apresentaram maiores quantidade de pontos errôneos enquanto que os dados obtidos com o monitor AFS $^{\circledR}$ apresentaram apenas dados considerados discrepantes. Com relação aos dados obtidos com o monitor FieldStar ${ }^{\circledR}$, o maior problema encontrado foi 0 intervalo de enchimento. Todos os erros apresentados pelos dados brutos são função da relação dinâmica entre o monitor e a máquina, e também de parâmetros do monitor. Espera-se que os erros e suas características sejam constantes enquanto não forem alteradas as relações monitor x máquina e os parâmetros do monitor. Quando da alteração das relações ou parâmetros, as características 
dos erros provavelmente não serão alteradas, mas espera-se que a metodologia seja eficaz em sua caracterização.

\subsection{Conclusões}

A metodologia desenvolvida para identificação de início e fim de passada de colheita é bastante confiável, permitindo a caracterização do intervalo de enchimento. A classificação dos erros possíveis de serem identificados em pósprocessamento dos dados levanta aspectos importantes da caracterização dos erros, fornecendo bases para que, por processo de filtragem, os pontos considerados errôneos possam ser removidos para elevar o nível qualitativo da informação contida em mapas de produtividade, qualquer que seja o monitor utilizado para a coleta de dados. 


\section{REMOÇÃO DE ERROS EM MAPAS DE PRODUTIVIDADE VIA FILTRAGEM DE DADOS BRUTOS}

\section{Resumo}

A automação do processo de obtenção do mapa de produtividade introduz erros nos dados coletados. Processos de filtragem de dados podem eliminar parte dos erros e elevar a qualidade da informação. O processo de filtragem desenvolvido trabalha com as características de cada erro presente no mapa de produtividade, apresentados em artigo anterior, que podem ser erros de posicionamento, produtividades improvavelmente altas e baixas, largura de plataforma incorreta, umidade de grãos, distância entre pontos, intervalo de enchimento e limites estatísticos para dados discrepantes. O filtro foi aplicado a seis conjuntos de dados, obtidos de seis diferentes monitores de produtividade comerciais. A análise geoestatística dos conjuntos de dados mostrou que a aplicação do filtro diminuiu o efeito pepita e obteve melhores resultados qualitativos na validação cruzada por krigagem, elevando a qualidade final da informação.

\section{Summary}

As yield data is collected automatically it allows for errors to be gathered together with good data. Filtering processes might be able to eliminate part of the errors and improve the quality of yield data. The develop of a filtering process may be set up based on the individual characteristic of each error, as presented in a previous paper. Those errors may be related to wrong position, too high or too low yield, swath width error, grain moisture error, null distance 
between points, filling time error and outliers. The filtering algorithm was implemented on six fields with data generated from six different commercial yield monitors. A geostatistical analysis of the data sets showed that the application of the filtering process decreased the nugget effect and improved the cross validation's quality index.

\subsection{Introdução}

Diversas definições tem sido propostas para a Agricultura de Precisão, mas todas convergem para o gerenciamento agrícola baseado na variabilidade espacial dos fatores de produção, visando lucro, sustentabilidade e redução do impacto ambiental. Nesse sistema baseado na variabilidade espacial, a coleta de informações é intensa. Estão inseridas as amostragens de solo, de folhas, bem como os mapas de produtividade, que traduzem a resposta da cultura em relação às práticas adotadas.

A medição da produtividade é um processo automático, a partir de sensores instalados em colhedoras, que são capazes de definir com relativa acurácia a quantidade de produto que está sendo colhida e a área onde foi produzida. Um receptor de GPS fornece o posicionamento georeferenciando a produção para possibilitar seu mapeamento. Por ser automático, o processo permite que grande quantidade de dados seja coletada, porém, permitindo que erros sejam introduzidos. Exemplos são dados coletados com a colhedora parada, erros de posicionamento e erros de leitura do sensor de produção.

A qualidade da informação torna-se fator primordial quando os mapas formam a base de dados que sustentará o processo de tomada de decisão. Os erros introduzidos pela automatização do processo podem levar a conclusões errôneas, apresentando áreas com produtividades irreais.

Este trabalho é a continuação de trabalho anterior que descreveu e caracterizou erros possíveis de serem identificados em mapas de produtividade após a produção do mapa e objetiva desenvolver uma rotina de filtragem de 
dados brutos, baseada nas características individuais de cada conjunto de dados que elimine os erros passíveis de identificação inseridos por monitores de produtividade comerciais durante o mapeamento da produtividade.

\subsection{Revisão de Literatura}

Desde o início da obtenção de mapas de produtividade diversos pesquisadores têm reportado a existência de erros nos mapas. Moore, (1998), trabalhou com dados de seis anos consecutivos de mapeamento de produtividade, identificou os seguintes erros: suavização, calibração de volume, largura incorreta da plataforma de corte e tempo de enchimento da colhedora. Blackmore \& Marshall (1996) citaram ainda os erros de posicionamento, erros devido à recirculação de grãos no mecanismo de trilha e retrilha da colhedora, perdas de grãos pela colhedora e a acurácia do sensor de produtividade, indicando a necessidade do desenvolvimento de rotinas para redução dos erros.

Uma das primeiras propostas de redução de erros em mapas de produtividade foi sugerida por Blackmore \& Marshall (1996) e denominada de Potential Mapping. A técnica desenvolvida propunha que os monitores de produtividade gravassem massa colhida ao invés de massa por área. Os dados seriam então inseridos num sistema de informações geográficas (SIG) para a definição da área que representaria cada ponto, sendo que a produtividade seria derivada no próprio SIG. Esta técnica eliminaria erros de medição de área e de largura de plataforma, uma vez que a área seria calculada após a colheita. Estes foram considerados pelos autores como os principais erros num mapa de produtividade. Posteriormente o Potential Mapping foi abandonado por ter sido identificada significativa quantidade de erros nas regiões das bordas dos talhões (Blackmore \& Moore, 1999). 
Rands ${ }^{2}$, citados por Blackmore \& Moore (1999) desenvolveram um conjunto de regras em linguagem " $\mathrm{C}$ " para a filtragem de dados brutos provenientes de um monitor específico de mercado. O programa checava os dados em busca de corrupção e eliminava dados corrompidos do arquivo original. Num arquivo texto eram inseridos os valores máximos e mínimos para que o programa tivesse parâmetros para a remoção de produtividades extremas. A rotina identificava pontos fora dos talhões e classificava-os como errôneos, pontos com pequenos erros de posicionamento eram reposicionados, tendo por base a rota da colhedora e a identidade do ponto. Outro fator considerado no desenvolvimento do filtro era a distância máxima entre pontos. A remoção do tempo de enchimento era feita removendo-se os primeiros 12 pontos de cada início de passada. Também eram removidos pontos gravados nos arremates da colheita do talhão. Os autores concluíram que a aplicação do filtro pode elevar significativamente a qualidade do mapa de produtividade.

Juerschik \& Giebel (1999) trabalharam com mapas de produtividade obtidos num talhão de 37 hectares durante as colheitas de trigo nos anos de 1995 e 1996, buscando correlações entre os mapas produzidos em diferentes anos para ratificar as práticas de agricultura de precisão baseadas em mapas de produtividade. Para a interpretação e análise de correlação dos mapas, identificaram a necessidade de filtragem de dados brutos. De modo bastante simples, utilizaram separadamente três filtros que classificavam como discrepantes os dados fora dos limites: média $\pm 1,64$ desvios padrão ( $90 \%$ dos dados); média \pm 2 desvios padrão ( $95 \%$ dos dados); média \pm 3 desvios padrão (99\% dos dados). Os autores consideraram que a exclusão de valores fora dos limites foi favorável ao aumento da correlação, mas que, por esse método, a exclusão de pontos reais foi prejudicial e deteriorou a análise de correlação. Uma das conclusões do estudo foi que a utilização do limite média \pm 2 desvios padrão foi favorável à análise de correlação se aplicada aos dados completos,

\footnotetext{
${ }^{2}$ RANDS, M. The development of na expert filter to improuve the quality of of yield mapping data. Sisoe, 1995. Thesys (M. Sc.) - Silsoe College.
} 
incluindo áreas de manobra e que, se forem analisados dados coletados fora das áreas de manobra e de cabeceiras, o limite de média \pm 3 desvios padrão era satisfatório.

Molin \& Gimenez (2000) propuseram um algoritmo de filtragem de dados brutos que avaliava cada ponto do arquivo produzido durante a colheita com relação a um desvio da média e também com relação ao desvio com um ponto coletado 15 posições atrás, buscando eliminar pontos coletados durante 0 tempo de enchimento. Analisaram também a distância entre pontos consecutivos, sendo eliminados pontos reprovados em qualquer dos testes. $O$ algoritmo eliminou de 22 a $41 \%$ dos pontos de dois mapas de produtividade. Os autores concluíram que a aplicação do algoritmo é simples, mas que cuidados devem ser tomados na definição dos parâmetros a serem utilizados.

Haneklaus, et al. (2000) elaboraram recomendações para a produção de mapas de produtividade com boa qualidade de dados, considerando a extração de dados problemáticos como uma das etapas obrigatórias. Consideraram natural a variação da umidade dos grãos de trigo de inverno dentro da faixa de 14 a $28 \%$, sendo eliminados pontos fora desse intervalo. Os autores também trabalharam com a eliminação de produtividades muito altas e muito baixas, tendo como parâmetros de definição pontos vizinhos destacados nos mapas de produtividade. Para a eliminação dos pontos, os autores selecionaram e retiraram manualmente os pontos destacados. Também foram eliminados pontos localizados fora do talhão, considerados com erro de localização. De acordo com os autores, o processo é bastante demorado e a aplicação de todas as etapas depende dos custos e da acurácia requerida.

Todos os monitores de produtividade geram pontos que, quando dispostos de maneira ordenada, baseados em suas coordenadas, formam o mapa de produtividade. Para combinar e comparar diferentes informações coletadas sobre a mesma área, todos os dados devem ser interpolados numa grade uniforme (Haneklaus, et al. 2000). Em agricultura de precisão, utilizam-se basicamente os algoritmos de interpolação denominados de inverso da 
distância a uma determinada potência e krigagem. De acordo com Isaaks \& Srivastava (1989), o método do inverso da distância estipula pesos aos pontos que são inversamente proporcionais à distância elevada a uma potência, que normalmente, é quadrática. Desta forma, o interpolador dá maior importância a valores mais próximos do ponto a ser estimado. Quanto maior o valor da potência, maior o peso de pontos mais próximos e menor a influência de pontos mais longínquos. A krigagem é um método de interpolação mais refinado, que leva em consideração a dependência espacial existente no fator interpolado.

A dependência espacial é explorada utilizando-se como ferramenta o semivariograma. A construção do semivariograma foi discutida por Isaaks \& Srivastava (1989), sendo que quatro parâmetros básicos podem ser estabelecidos. O alcance (range) é a distância em que a variância da amostragem se torna aleatória, a partir da qual não há mais dependência espacial. Patamar (sill) é a semivariância atingida pelas amostras no platô, e pode ser equivalente à variância das amostras. Efeito pepita (nugget) é a porção da variância aleatória e não explicada pela amostragem. O quarto parâmetro é o modelo de equação que foi ajustado aos dados no semivariograma. Estes parâmetros são inseridos no modelo de krigagem para a produção do mapa de produtividade em superfície. A validação cruzada é uma técnica que permite a comparação de valores estimados pelo interpolador, baseado no modelo ajustado aos dados na análise de dependência espacial, com valores reais. Os resultados da validação cruzada podem ser avaliados com ferramentas da estatística, como por exemplo, a análise de correlação linear como índice qualitativo. 


\subsection{Material e Métodos}

No processo de filtragem de dados, o material inicial é composto por dados brutos que provêm diretamente do monitor de produtividade, quando os arquivos são gravados em texto, ou do programa específico de cada monitor, quando é gerado em código, e então convertido em formato texto. Os arquivos brutos contêm erros grosseiros de posicionamento, de produtividade nula ou ausente, de interpretação de largura de plataforma, de umidade nula ou valor ausente de umidade, de distância nula entre pontos, de intervalo de enchimento além de valores discrepantes de produtividade. Para a realização do trabalho foi utilizado um conjunto de dados obtidos com seis diferentes monitores de produtividade comerciais (Quadro 1). A Figura 1 mostra o fluxograma que representa as etapas de aplicação do processo de filtragem.

\begin{tabular}{|c|c|c|c|c|}
\hline Monitores & Culturas & $\begin{array}{c}\text { Áreas } \\
\text { (ha) }\end{array}$ & $\begin{array}{l}\text { Número } \\
\text { de pontos } \\
\text { coletados }\end{array}$ & $\begin{array}{l}\text { Densidade } \\
\text { de pontos } \\
\text { (pontos/ha) }\end{array}$ \\
\hline RDS $^{\circledR}$ Ceres 2 & Milho safrinha & 22,0 & 12022 & 546 \\
\hline RDS $^{\circledR}$ Pro Series 8000 & Soja & 22,0 & 9955 & 452 \\
\hline GreenStar $^{\circledR}$ & Milho & 17,7 & 29631 & 1674 \\
\hline FieldStar $^{\circledR}$ & Soja & 78,0 & 19309 & 247 \\
\hline $\mathrm{AFS}^{\circledR}$ & Soja & 42,2 & 9047 & 214 \\
\hline New Holland ${ }^{\circledR}$ & Trigo & 12,6 & 8356 & 663 \\
\hline
\end{tabular}




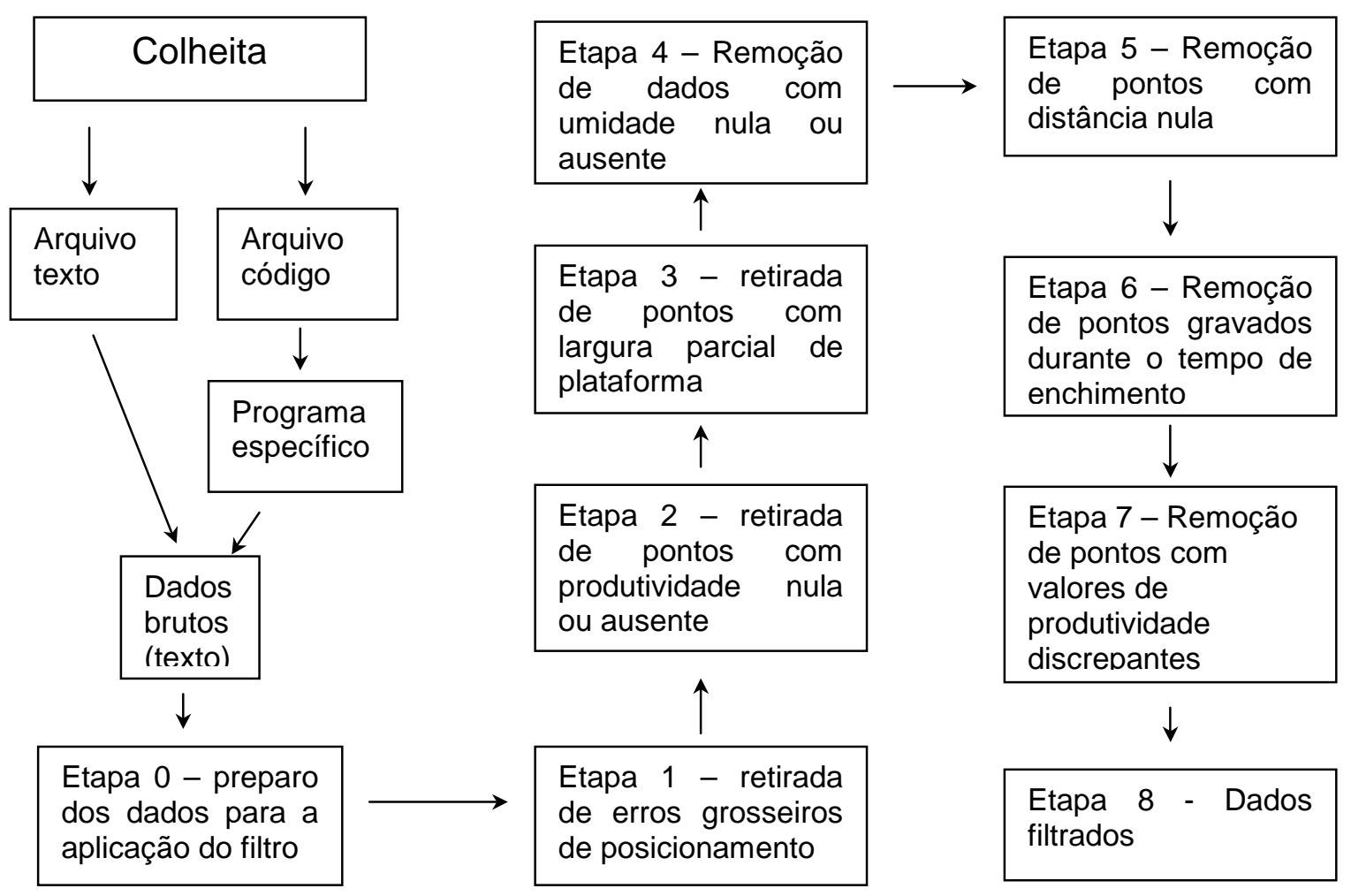

Figura 1 - Fluxograma de etapas de aplicação do processo de filtragem de dados brutos.

Os dados brutos, no formato texto, foram abertos em planilhas eletrônicas para a aplicação do filtro. No preparo dos dados, as coordenadas geodésicas foram convertidas em métricas pela projeção UTM 1983. Com base nessas coordenadas, foi calculada a distância entre os pontos através do Teorema de Pitágoras. Para a determinação do sentido e direção de deslocamento da colhedora foi calculado o índice de deslocamento. $O$ índice foi calculado nas direções Norte (ID(N)) e Leste (ID(L)) de acordo com as equações (1) e (2) e a interpretação dos sinais pode ser vista na Tabela 1. Apenas um dos índices é suficiente para a caracterização do percurso da colhedora, sendo que a escolha depende da direção predominante no talhão. Também foi inserida uma coluna contendo um índice de identificação de cada ponto. Ainda nesta etapa, o arquivo é preparado para a aplicação do algoritmo para eliminação do intervalo 
de enchimento, sendo necessário que as duas últimas colunas do arquivo sejam, na ordem, índice de deslocamento (Norte ou Leste) e produtividade.

$$
\begin{array}{r}
I D(N)=X(i)-X(i+1) \\
I D(L)=Y(j)-Y(j+1)
\end{array}
$$

onde:

ID(N) é o índice de deslocamento na direção Norte-Sul;

$\mathrm{ID}(\mathrm{L})$ é o índice de deslocamento na direção Leste-Oeste;

$X$ é a coordenada Norte da colhedora;

i é o ponto na direção N-S e sentido considerado;

Y é a coordenada Leste da colhedora;

j é o ponto na direção L-O e sentido considerado.

Tabela 1. Interpretação do Índice de deslocamento (ID).

\begin{tabular}{cccc}
\hline & Valores & Direções & Sentidos \\
\hline $\mathrm{ID}(\mathrm{N})$ & negativo & $\mathrm{N}-\mathrm{S}$ & Sul->Norte \\
& positivo & $\mathrm{N}-\mathrm{S}$ & Norte->Sul \\
$\mathrm{ID}(\mathrm{L})$ & positivo & $\mathrm{L}-\mathrm{O}$ & Leste->Oeste \\
& negativo & $\mathrm{L}-\mathrm{O}$ & Oeste->Leste \\
\hline
\end{tabular}

Os dados foram então inseridos num sistema de informações geográficas (SIG) para a retirada de erros grosseiros de posicionamento, representado por pontos fora do talhão. Tais pontos foram selecionados e retirados do conjunto de dados (etapa 1). Na segunda etapa foram selecionados e retirados do conjunto, dados com valores de produtividade nula ou ausente.

A terceira etapa consiste na seleção e retirada de dados coletados com largura de plataforma parcial, selecionando-se todos os pontos com largura de plataforma diferente da largura máxima informada ao sistema, incluindo-se pontos com largura de plataforma nula. Na quarta etapa foram selecionados e retirados pontos com umidade nula. A quinta etapa, realizada no SIG, é a 
retirada de pontos com distância nula entre si. Após esta etapa, os dados foram gravados em formato texto e abertos em planilha eletrônica.

A sexta etapa compreende a caracterização e retirada de pontos gravados durante o intervalo de enchimento da colhedora. Para a caracterização do intervalo de enchimento, foram escolhidas cinco passadas aleatórias de colheita. Foi calculada a produtividade média em função da distância do início da passada, limitada em $50 \mathrm{~m}$. A produtividade máxima ocorrida dentro do intervalo foi verificada e os valores de produtividade foram então convertidos em percentagem da máxima produtividade observada. $O$ espaço relativo ao intervalo de enchimento foi definido como o espaço necessário para que a produtividade média atinja $90 \%$ da produtividade máxima.

Considerando-se todos os pontos do arquivo, foi calculada a distância média entre pontos e o número de pontos a serem eliminados no início de cada passada de colheita. Para tanto, foi utilizada a equação (3), sendo que o valor obtido foi sempre arredondado para cima sem casas decimais, em caso de frações.

$$
N=\frac{I E}{D M}
$$

onde:

$\mathrm{N}$ é o número de pontos a ser eliminado após o início da passada de colheita; IE é o intervalo de enchimento, em metros;

DM é a distância média entre pontos.

O número de pontos coletados dentro do intervalo de enchimento $(N)$ foi inserido num algoritmo para identificar e eliminar tal erro. $O$ algoritmo pode ser dividido em duas partes estruturais para facilitar a compreensão. A primeira parte do algoritmo testa os dados para identificar início de passada. Foi adotado, como critério de estabilidade, a ocorrência de cinco pontos consecutivos com o mesmo sinal de ID, sendo que, a alteração do sinal de qualquer ponto dentro deste intervalo resulta em valor falso, interpretado pelo 
algoritmo como início de passada. Em caso verdadeiro, o algoritmo repete o valor de produtividade e segue para o próximo ponto.

Se o algoritmo identificou início de passada, a primeira providência é testar se o ponto analisado está dentro do intervalo de enchimento. Para tanto é checado o sinal do ID dos n pontos anteriores, onde $\mathrm{n}$ é o número de pontos a serem eliminados após o início da passada. Se nos $\mathrm{N}$ pontos anteriores há mudança de sinal do ID, então o teste retorna falso e altera o valor de produtividade para valor nulo. Se não há alteração de sinal dentro do intervalo verificado, então o ponto está fora do intervalo de enchimento e o algoritmo retorna verdadeiro, sendo mantido o valor da produtividade. Tal procedimento pode ser visualizado na Figura 2, que representa o fluxograma de atuação do algoritmo. O algoritmo é exemplificado na equação (4), com critério de estabilidade de 5 pontos e eliminação de 4 pontos após o início da passada.

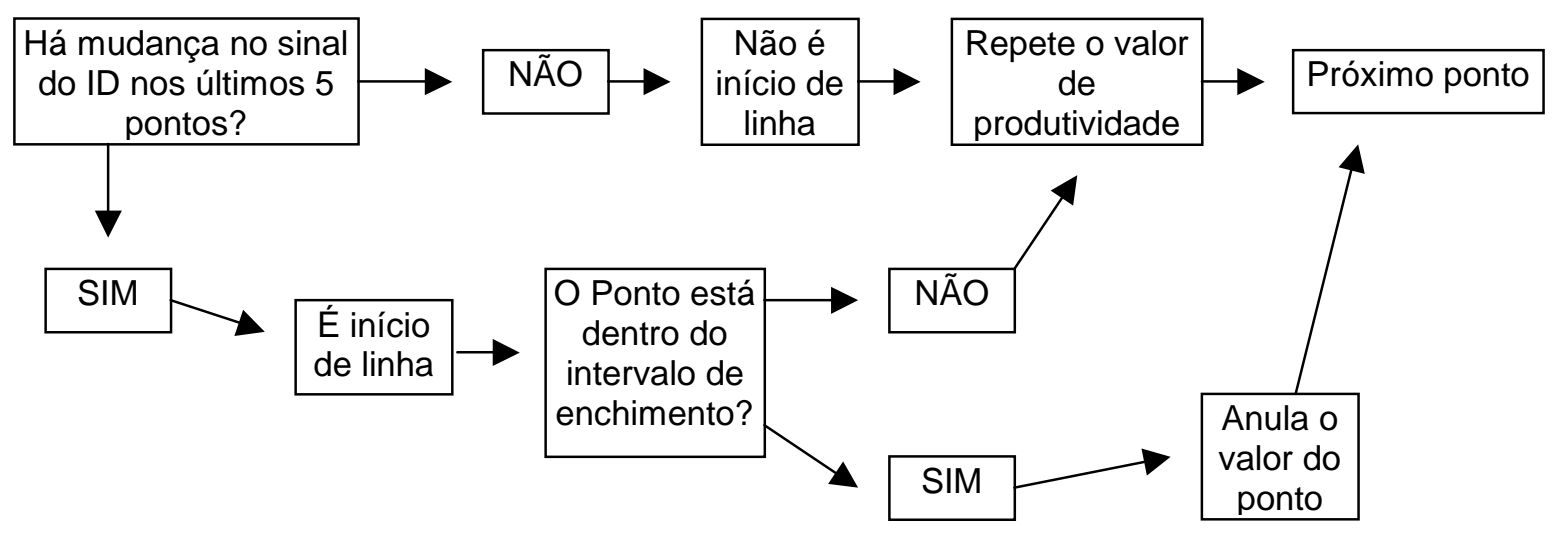

Figura 2 - Fluxograma da atuação do algoritmo para eliminação do intervalo de enchimento. 
SE

$(\mathrm{N}(\mathrm{i})<0 \mathrm{EN}(\mathrm{i}-1)<0 \mathrm{EN}(\mathrm{i}-2)<0 \mathrm{EN}(\mathrm{i}-3)<0 \mathrm{EN}(\mathrm{i}-4)<0)$

\section{OU}

$(\mathrm{N}(\mathrm{i})>0 \quad \mathrm{E} \mathrm{N}(\mathrm{i}-1)>0 \quad \mathrm{EN}(\mathrm{i}-2)>0 \quad \mathrm{E} \mathrm{N}(\mathrm{i}-3)>0 \quad \mathrm{EN}(\mathrm{i}-4)>0)$

\section{ENTÃO}

$\mathrm{M}(\mathrm{i})$

\section{CASO CONTRÁRIO}

SE $\quad(\mathrm{N}(\mathrm{i})>0$ E N $(\mathrm{i}-1)>0$ E N(i-2) $>0$ E N $(\mathrm{i}-3)>0 ; \mathrm{N}(\mathrm{i}-4)>0)$

OU

$(\mathrm{N}(\mathrm{i})<0$ E N(i-1)<0 E N(i-2)<0 E N(i-3)<0 E N(i-4)<0)

\section{ENTÃO}

\section{$\mathrm{M}(\mathrm{i})$ \\ CASO CONTRÁRIO}

0

\section{FIM}

\section{FIM}

onde:

$\mathrm{N}$ (i) são os valores de ID e

M(i) são valores de produtividade.

Após a aplicação deste algoritmo, os valores com produtividade anulada foram eliminados do conjunto de dados. Os dados foram então reordenados com base na coluna de identificação dos pontos para manter a seqüência original.

A sétima etapa consistiu-se na análise exploratória dos dados em busca de dados discrepantes do conjunto. Foram calculadas as medidas de posição mediana, quartil superior, quartil inferior e amplitude interquartílica. Com base na metodologia proposta por Tukey (1977), os limites superior (equação 5) e inferior (equação 6) foram calculados, procedendo-se a eliminação de pontos 
cujos valores de produtividade estão fora dos limites estabelecidos. Os dados foram então reordenados pela identidade de cada ponto, findando o processo de filtragem.

$$
\begin{aligned}
& L S=Q S+1,5 . A I \\
& L I=Q I-1,5 . A I
\end{aligned}
$$

onde:

LS é o limite superior;

LI é o limite inferior;

QS é o quartil superior;

QI é o quartil inferior e

Al é amplitude interquartílica.

A metodologia de filtragem foi aplicada ao conjunto de dados exemplo. Após a realização de cada etapa, foi realizada a contagem dos pontos restantes e totalização daqueles retirados do mapa. Foram construídos histogramas de distribuição de freqüência de dados brutos e dados filtrados. Também foi feita análise de dependência espacial para os dados, antes e depois do processo de filtragem, sendo que os parâmetros de ajuste dos modelos foram comparados. Por motivos de limitação computacional, foram selecionados cerca de 1000 pontos de cada arquivo, localizados numa faixa diagonal ao talhão, de modo que todas as áreas representativas fossem amostradas. Os modelos ajustados aos dados brutos e filtrados foram comparados por meio da validação cruzada, utilizando-se correlação linear como medida qualitativa do ajuste. 


\subsection{Resultados e Discussão}

A primeira etapa do processo foi referente à eliminação de pontos com erros grosseiros de posicionamento. Os dados coletados com os monitores AFS $^{\circledR}$, New Holland ${ }^{\circledR}$, RDS $^{\circledR}$ Ceres 2, RDS ${ }^{\circledR}$ Pro Series 8000 e FieldStar ${ }^{\circledR}$ apresentaram tal erro, tendo sido eliminados do conjunto percentagens que variaram de 0,1 a $7,8 \%$ dos dados.

A segunda etapa do processo de filtragem retirou pontos com produtividade nula dos arquivos utilizados como exemplo. É importante salientar que erros de medida da produtividade ou inacurácia do sensor não são detectados por essa metodologia, apenas pontos em que não houve leitura da produtividade. A mesma lógica pode ser aplicada à eliminação de pontos com umidade nula; o processo não identifica erros de leitura do sensor, apenas ausência de valor ou valores nulos. Por outro lado, a eliminação de erros devido à interpretação errônea da largura de plataforma de corte através da eliminação de pontos com largura parcial de corte, elimina apenas os pontos assinalados pelo operador com largura parcial. O processo não é capaz de identificar pontos que foram gerados com largura parcial de plataforma e que não foram informados ao sistema.

A Tabela 2 apresenta o resumo do processo de filtragem, indicando a retirada de pontos em função de cada etapa aplicada aos dados. 
Tabela 2. Síntese do processo de filtragem indicando o número e a porcentagem de pontos restantes de cada arquivo de dados brutos.

\begin{tabular}{|c|c|c|c|c|c|c|c|c|c|c|c|c|}
\hline \multirow{3}{*}{ Filtro aplicado } & \multicolumn{12}{|c|}{ Monitores em que os arquivos foram gerados } \\
\hline & \multicolumn{2}{|c|}{ GreenStar $^{\circledR}$} & \multicolumn{2}{|c|}{$\mathrm{AFS}^{\circledR}$} & \multicolumn{2}{|c|}{ New Holland ${ }^{\circledR}$} & \multicolumn{2}{|c|}{$\begin{array}{c}\mathrm{RDS}^{\circledR} \\
\text { Ceres } 2 \\
\end{array}$} & \multicolumn{2}{|c|}{$\begin{array}{c}\text { RDS }^{\circledR} \text { Pro } \\
\text { Series } 8000\end{array}$} & \multicolumn{2}{|c|}{ FieldStar $^{\circledR}$} \\
\hline & $\begin{array}{c}\text { Pontos } \\
\text { restantes }\end{array}$ & (\%) & $\begin{array}{l}\text { Pontos } \\
\text { restantes }\end{array}$ & (\%) & $\begin{array}{l}\text { Pontos } \\
\text { restantes }\end{array}$ & (\%) & $\begin{array}{l}\text { Pontos } \\
\text { restantes }\end{array}$ & (\%) & $\begin{array}{c}\text { Pontos } \\
\text { restantes }\end{array}$ & $(\%)$ & $\begin{array}{c}\text { Pontos } \\
\text { restantes }\end{array}$ & $(\%)$ \\
\hline $\begin{array}{l}\text { Dados } \\
\text { originais } \\
\text { Erros }\end{array}$ & 29631 & 100,0 & 9047 & 100,0 & 8356 & 100,0 & 12022 & 100,0 & 9955 & 100,0 & 19309 & 100,0 \\
\hline $\begin{array}{l}\text { grosseiros de } \\
\text { posicionamen } \\
\text { to }\end{array}$ & 29631 & 100,0 & 9028 & 99,8 & 8033 & 96,1 & 11918 & 99,1 & 9182 & 92,2 & 19299 & 99,9 \\
\hline $\begin{array}{l}\text { Produtividade } \\
\text { nula }\end{array}$ & 28958 & 97,7 & 8998 & 99,5 & 7895 & 94,5 & 11883 & 98,8 & 9182 & 92,2 & 19299 & 99,9 \\
\hline $\begin{array}{l}\text { Interpretação } \\
\text { de largura de } \\
\text { plataforma }\end{array}$ & 27394 & 92,5 & 8891 & 98,3 & 7606 & 91,0 & 10412 & 86,6 & 8858 & 89,0 & 19299 & 99,9 \\
\hline $\begin{array}{l}\text { Umidade } \\
\text { nula }\end{array}$ & 26201 & 88,4 & 8797 & 97,2 & 7577 & 90,7 & 10377 & 86,3 & 8500 & 85,4 & 19299 & 99,9 \\
\hline $\begin{array}{l}\text { Distância } \\
\text { nula }\end{array}$ & 23408 & 79,0 & 8797 & 97,2 & 7573 & 90,6 & 10374 & 86,3 & 8500 & 85,4 & 19299 & 99,9 \\
\hline $\begin{array}{l}\text { Intervalo de } \\
\text { enchimento }\end{array}$ & 23408 & 79,0 & 8797 & 97,2 & 7096 & 84,9 & 9991 & 83,1 & 8099 & 81,4 & 18548 & 96,1 \\
\hline $\begin{array}{l}\text { Dados } \\
\text { discrepantes }\end{array}$ & 21537 & 72,7 & 8635 & 95,4 & 7006 & 83,8 & 9706 & 80,7 & 7830 & 78,7 & 18127 & 93,9 \\
\hline $\begin{array}{l}\text { Pontos } \\
\text { retirados (\%) }\end{array}$ & & 27,3 & & 4,6 & & 16,2 & & 19,3 & & 21,3 & & 6,1 \\
\hline
\end{tabular}

A retirada de pontos pelo processo de filtragem variou de 4,6 a $27,3 \%$ para os dados obtidos com os monitores $\mathrm{AFS}^{\circledR}$ e GreenStar $^{\circledR}$, respectivamente. A freqüência de coleta de pontos de produtividade foi bastante diferente entre os monitores, resultando em densidades de amostragem diferentes. Os dados obtidos com o monitor GreenStar $^{\circledR}$ apresentaram alta densidade e a retirada de $27,3 \%$ dos pontos reduziu essa densidade de 1676 para 1218 pontos.ha $^{-1}$, enquanto que para o monitor $\mathrm{AFS}^{\circledR}$ a densidade abaixou de 214 para 205 pontos.ha ${ }^{-1}$ (Tabela 3). 
Tabela 3. Densidade de coleta de pontos antes e depois da aplicação do filtro para dos dados coletados com os diferentes monitores.

\begin{tabular}{ccccccc}
\hline & \multicolumn{5}{c}{ Monitores em que os arquivos foram gerados } \\
\cline { 2 - 7 } & \multicolumn{5}{c}{ RDS $^{\circledR}$ Pro } \\
Densidades & & New & RDS $^{\circledR}$ & Series \\
(pontos.ha $^{-1}$ ) & GreenStar $^{\circledR}$ & AFS $^{\circledR}$ & Holland $^{\circledR}$ & Ceres 2 & 8000 & FieldStar $^{\circledR}$ \\
\hline Iniciais & 1676 & 214 & 661 & 546 & 453 & 247 \\
Finais & 1218 & 205 & 554 & 441 & 356 & 232 \\
\hline
\end{tabular}

A alteração do arquivo original pelas diversas etapas do processo de filtragem é função da existência do erro no arquivo de dados brutos e também das interações existentes entre os erros apresentados pelos monitores. Em diversas ocasiões, o mesmo ponto apresentava dois ou mais tipos de erros, e a primeira etapa que o identificasse, eliminaria o ponto. Todas as etapas do processo de filtragem foram efetivamente utilizadas nos dados obtidos com os monitores New Holland ${ }^{\circledR}$ e RDS ${ }^{\circledR}$ Ceres 2. Para o monitor GreenStar ${ }^{\circledR}$ apenas não foi efetiva a sexta etapa, sendo que o efeito do intervalo de enchimento foi retirado pela ação dos filtros anteriores, embora esse tipo de erro tenha sido identificado nos dados brutos. O conjunto de dados obtidos com o monitor $\mathrm{AFS}^{\circledR}$ não sofreu alterações com a aplicação das etapas 4,5 e 6 , que representam a retirada de pontos com problemas de leitura de umidade, distância nula entre pontos e de intervalo de enchimento. Durante o processo de filtragem dos dados obtidos com o monitor RDS ${ }^{\circledR}$ Ceres 2 apenas o filtro de distância nula entre pontos não eliminou dados do conjunto. Para o arquivo obtido com o monitor RDS ${ }^{\circledR}$ Pro Series 8000 , as etapas 2 e 5, representadas pelos filtros de produtividade e distância nulas, não modificaram o arquivo. $\mathrm{A}$ filtragem dos dados obtidos com o monitor FieldStar ${ }^{\circledR}$ foi efetiva durante a aplicação das etapas 1, 6 e 7 apenas, sendo que as demais etapas não eliminaram pontos do arquivo. A inversão da ordem de aplicação dos filtros em qualquer dos exemplos teria alterado a distribuição do número de pontos 
eliminados entre as etapas, mas não alteraria a quantidade total de pontos eliminados.

O processo de filtragem dos dados atuou principalmente nos pontos localizados nas extremidades da distribuição de freqüência dos mapas de produtividade. Como exemplo, a Figura 3 mostra os histogramas de distribuição de freqüência de ocorrência de produtividade para os dados obtidos com o monitor GreenStar ${ }^{\circledR}$ antes e depois do processo de filtragem, durante o qual foram retirados $27,3 \%$ dos pontos. A aplicação do filtro aumentou ligeiramente a freqüência de ocorrência das classes em função da eliminação de pontos, mas não alterou as tendências da distribuição, mantendo a alta ocorrência de produtividade nas classes de 6,5 a 10 t.ha $^{-1}$.
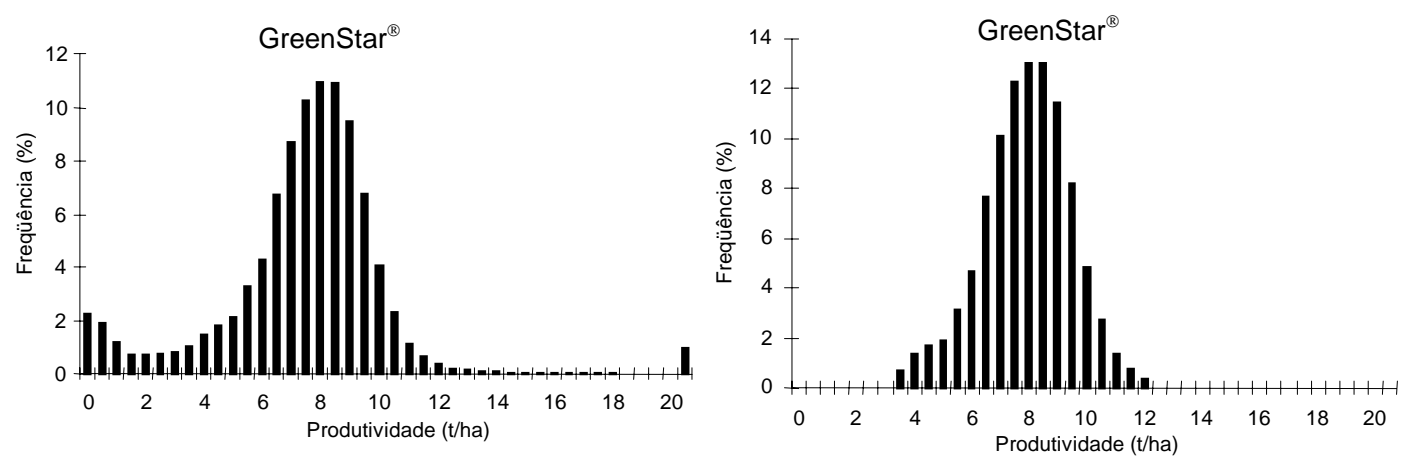

Figura 3 - Distribuição de freqüência de ocorrência de produtividade para o exemplo dos dados obtidos com o monitor GreenStar ${ }^{\circledR}$ antes (esquerda) e depois (direita) do processo de filtragem.

Em todos os conjuntos de dados exemplos trabalhados, foram eliminados pontos nas extremidades da curva de distribuição a partir da inflexão demonstrada pela distribuição dos dados brutos. A definição dos limites superior e inferior (Tabela 4) para dados discrepantes permitiu a eliminação de pontos improváveis, sendo que os limites calculados coincidiriam com as inflexões da distribuição de freqüência. 
Tabela 4. Limites estatísticos calculados para os dados durante o processo de filtragem.

\begin{tabular}{ccccccc}
\hline & \multicolumn{6}{c}{ Monitor em que os arquivos foram gerados } \\
\cline { 2 - 7 } Fator & GreenStar $^{\circledR}$ & AFS $^{\circledR}$ & $\begin{array}{c}\text { New } \\
\text { Holland }\end{array}$ & $\begin{array}{c}\text { RDS }^{\circledR} \\
\text { Ceres 2 }\end{array}$ & $\begin{array}{c}\text { RDS }^{\circledR} \text { pro } \\
\text { Series 8000 }\end{array}$ & FieldStar $^{\circledR}$ \\
\cline { 2 - 7 } & 8,68 & 3,73 & 4,53 & 5,04 & 5,34 & 3,36 \\
Quartil Superior & 2,71 & 3,37 & 4,35 & 3,54 & 2,74 \\
Quartil Inferior & 6,46 & 1,02 & 1,15 & 0,69 & 1,80 & 0,62 \\
$\begin{array}{c}\text { Amplitude } \\
\text { interquartílica }\end{array}$ & 2,22 & 5,26 & 6,26 & 6,08 & 0,84 & 1,82 \\
Limite Superior & 12,02 & 5,02 & 8,03 & 4,28 \\
Limite Inferior & 3,13 & 1,18 & 1,64 & 3,32 & 8,03 \\
\hline
\end{tabular}

O histograma de distribuição de freqüência de ocorrência dos dados obtidos com 0 monitor $\mathrm{AFS}^{\circledR}$ pode ser visto na Figura 4 e exemplifica a distribuição de freqüência de ocorrência numa situação de ação branda do filtro. Neste caso, apenas 4,6\% dos pontos foram retirados (Tabela 2).
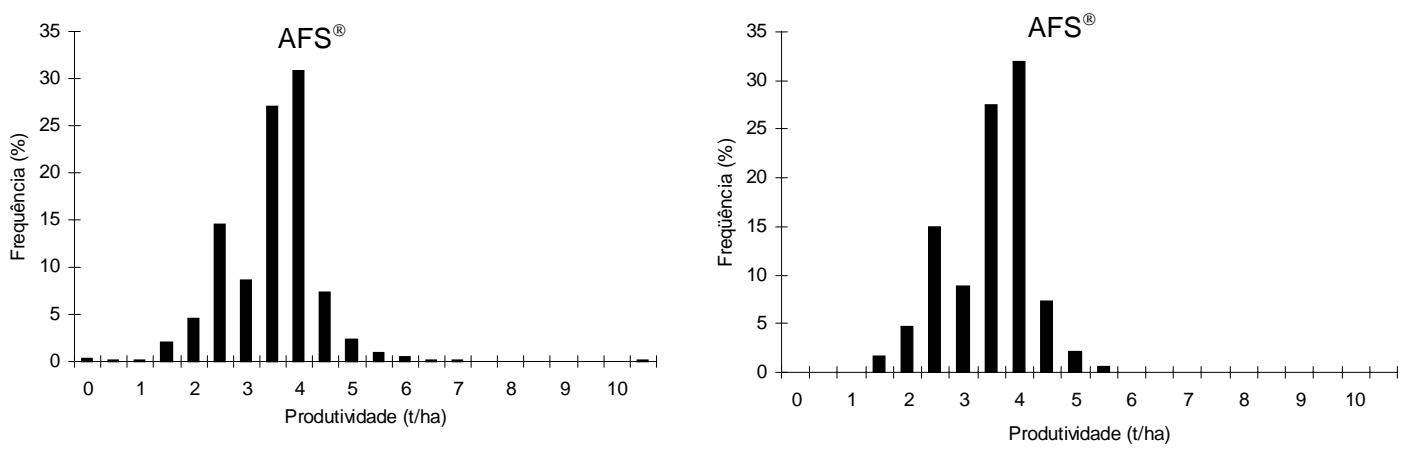

Figura 4 - Distribuição de freqüência de ocorrência de produtividade para os dados obtidos com o monitor $\mathrm{AFS}^{\circledR}$ antes (esquerda) e depois do processo de filtragem (direita).

Pode-se notar grande semelhança entre ambas situações, sendo que a ação do filtro ficou restrita aos pontos com produtividade maiores ou menores que os limites de 5,26 e 1,18 tha ${ }^{-1}$ (Tabela 4).

A Tabela 5 mostra as características do erro de intervalo de enchimento para os arquivos utilizados para aplicação do filtro. Os dados obtidos com os 
monitores GreenStar $^{\circledR}$ e $\mathrm{AFS}^{\circledR}$ não apresentaram intervalo de enchimento, enquanto que para os demais monitores, o intervalo de enchimento variou de 14 a 25 m após o início da colheita. A eliminação de pontos coletados durante o intervalo de enchimento pode ser vista na Figura 4, onde a ação do algoritmo é exemplificada com o mapa de produtividade produzido com dados do monitor FieldStar $^{\circledR}$.

Tabela 5. Parâmetros levantados para caracterização e eliminação do erro de intervalo de enchimento para os arquivos exemplo.

\begin{tabular}{ccccccc}
\hline & \multicolumn{5}{c}{ Monitor em que os arquivos foram gerados } \\
\cline { 2 - 6 } & GreenStar $^{\circledR}$ & AFS $^{\circledR}$ & $\begin{array}{c}\text { New } \\
\text { Holland }\end{array}$ & $\begin{array}{c}\text { RDS }^{\circledR} \\
\text { Ceres 2 }\end{array}$ & $\begin{array}{c}\text { RDS }^{\circledR} \text { Pro } \\
\text { Series 8000 }\end{array}$ & FieldStar $^{\circledR}$ \\
\hline $\begin{array}{c}\text { Intervalo de } \\
\text { enchimento (m) }\end{array}$ & 0 & 0 & 14 & 20 & 22 & 25 \\
$\begin{array}{c}\text { Distância média entre } \\
\text { pontos (m) } \\
\mathrm{N}^{1} \text { (eq 3) }\end{array}$ & 0 & 0 & 4 & 5 & 5,67 & 5,45 \\
\hline número de pontos a serem removidos no início de cada passada de colheita
\end{tabular}
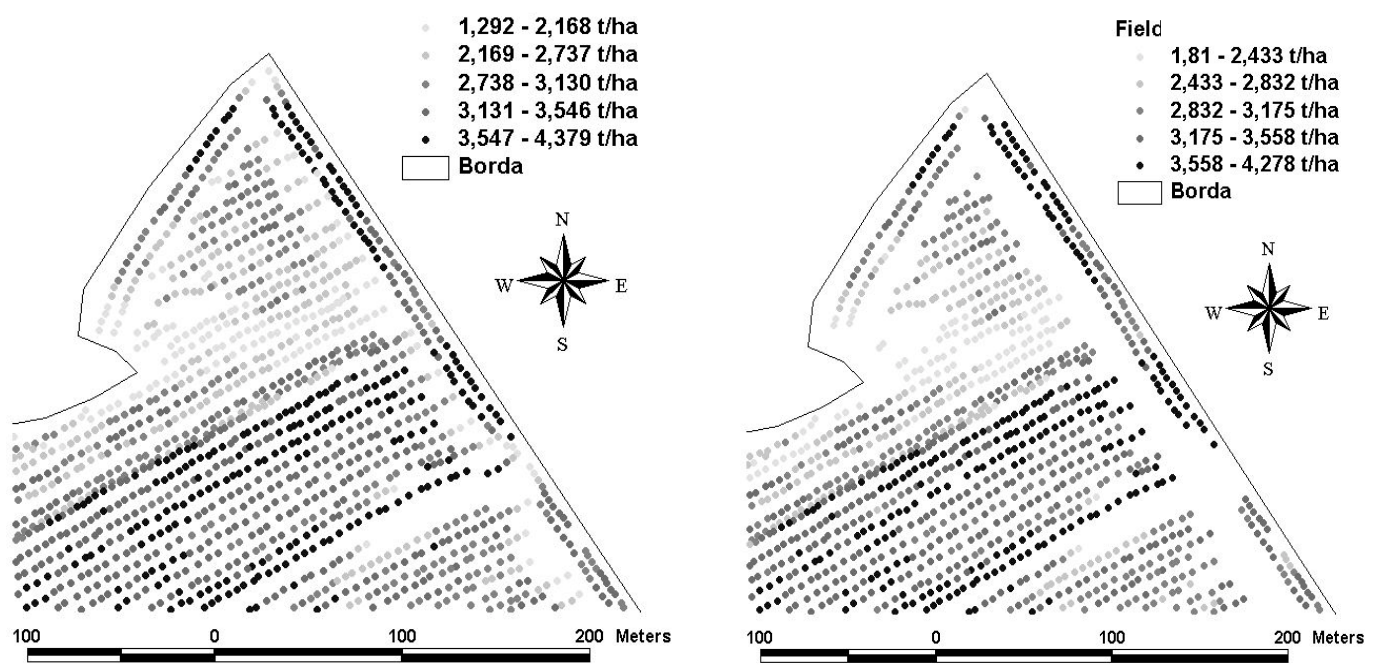

Figura 5 - Resultados da aplicação da sexta etapa do processo de filtragem (direita) que corresponde à eliminação do erro devido ao intervalo de enchimento, em comparação com o mapa produzido a partir de dados brutos (esquerda). 
O algoritmo atuou fortemente nas zonas de cabeceira dos talhões, eliminando pontos coletados durante o intervalo de enchimento. As passadas que tiveram pontos eliminados (Figura 5) correspondem às passadas em que a colhedora iniciou a colheita na área mostrada. Foram eliminados os 5 primeiros pontos de cada início delas, resultando na diminuição da quantidade de pontos cinza claro nas cabeceiras. A ausência de outros pontos no arquivo é devido às ações das etapas anteriores à remoção do intervalo de enchimento.

A Figura 6 mostra um exemplo da seleção de dados utilizados na análise de dependência espacial. Os coeficientes ajustados aos semivariogramas produzidos com dados brutos e filtrados podem ser vistos na Tabela 6. A título de exemplo, os semivariogramas ajustados aos dados brutos e filtrados do monitor $\mathrm{AFS}^{\circledR}$ podem ser vistos na Figura 7.

Tabela 6. Parâmetros de ajuste do semivariograma para os dados brutos e filtrados.

\begin{tabular}{|c|c|c|c|c|c|c|}
\hline \multirow{3}{*}{ Monitor } & \multicolumn{6}{|c|}{ Parâmetros } \\
\hline & \multirow[t]{2}{*}{ Arquivo } & \multirow[t]{2}{*}{ Modelo } & Pepita & Patamar & Alcance & $\begin{array}{c}\text { Validação } \\
\text { cruzada }\end{array}$ \\
\hline & & & $\Upsilon^{*}$ & $\Upsilon$ & (m) & \\
\hline \multirow{2}{*}{$\mathrm{AFS}^{\circledR}$} & Bruto & Gaussiano & 0,32 & 1,32 & 550,00 & 0,56 \\
\hline & Filtrado & Gaussiano & 0,14 & 1,00 & 500,00 & 0,68 \\
\hline \multirow{2}{*}{ New Holland ${ }^{\circledR}$} & Bruto & Gaussiano & 1,20 & 3,20 & 850,00 & 0,38 \\
\hline & Filtrado & Esférico & 0,27 & 0,70 & 17,36 & 0,58 \\
\hline \multirow{2}{*}{ RDS $^{\circledR}$ Ceres 2} & Bruto & exponencial & 1604000,00 & 3209000,00 & 171,00 & 0,47 \\
\hline & Filtrado & exponencial & 0,09 & 0,17 & 64,50 & 0,62 \\
\hline \multirow{2}{*}{$\begin{array}{l}\text { RDS }^{\circledR} \text { Pro Series } \\
8000\end{array}$} & Bruto & Pepita & - & - & - & - \\
\hline & Filtrado & Pepita & - & - & - & - \\
\hline \multirow{2}{*}{ FieldStar $^{\circledR}$} & Bruto & exponencial & 0,02 & 0,17 & 117,43 & 0,85 \\
\hline & Filtrado & exponencial & 0,00 & 0,09 & 28,05 & 0,83 \\
\hline \multirow{2}{*}{ GreenStar $^{\circledR}$} & Bruto & Esférico & 1,45 & 3,95 & 18,87 & 0,71 \\
\hline & Filtrado & exponencial & 0,58 & 2,02 & 42,90 & 0,75 \\
\hline
\end{tabular}

ré a semivariância 


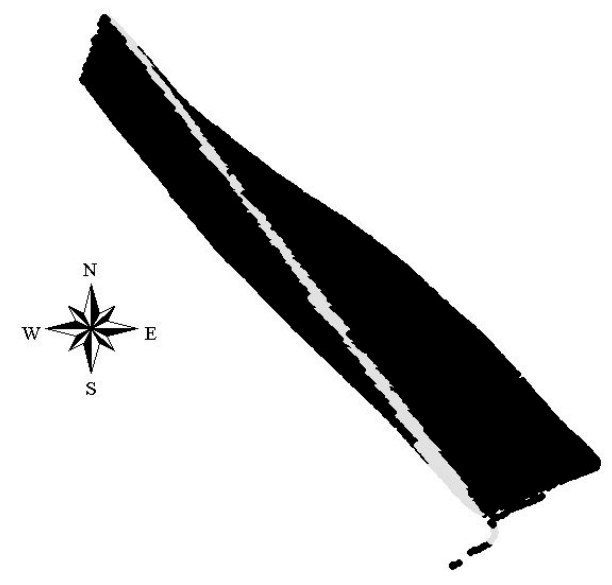

Figura 6 - Exemplo de seleção de pontos para a realização da análise de dependência espacial; os pontos selecionados no arquivo obtido com o monitor RDS ${ }^{\circledR}$ Ceres 2 aparecem em cinza.
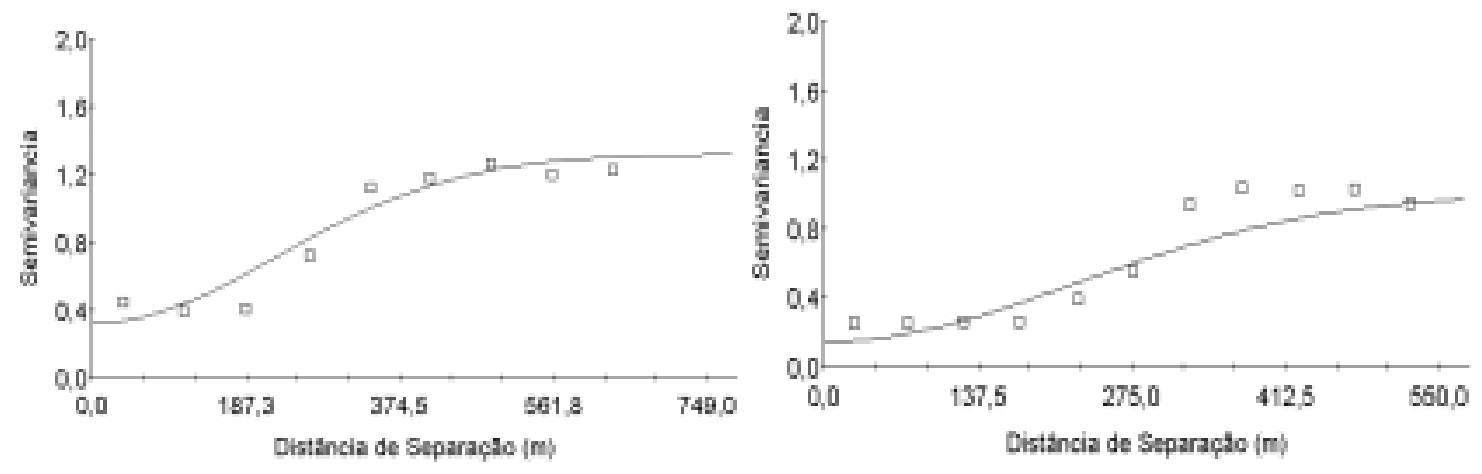

Figura 7 - Semivariogramas ajustados aos dados coletados com o monitor de produtividade $\mathrm{AFS}^{\circledR}$ antes (esquerda) e depois do processo de filtragem (direita).

De maneira geral, o processo de filtragem contribuiu para a caracterização da dependência espacial, reduzindo a variabilidade não explicada pelos modelos ajustados aos dados. Apenas os dados obtidos com o monitor RDS ${ }^{\circledR}$ Pro Series 8000 não apresentaram dependência espacial. Na Figura 7 pode-se observar a redução do efeito pepita de 0,32 para $0,14 \Upsilon$ devido à atuação do processo de filtragem (Tabela 6). Especialmente com relação aos dados obtidos 
com o monitor RDS ${ }^{\circledR}$ Ceres 2, o processo de filtragem foi bastante benéfico, reduzindo o efeito pepita de 1604000 para 0,09 . Tamanha redução é devido à presença de valores 9999,9 t.ha ${ }^{-1}$ no arquivo de dados brutos de produtividade. A presença destes valores, normalmente nas cabeceiras, eleva consideravelmente a semivariância. $O$ processo de filtragem melhorou a validação cruzada dos modelos ajustados, que representa a correlação entre valores reais e preditos pelo modelo, aos dados obtidos com os monitores RDS $^{\circledR}$ Ceres 2, AFS ${ }^{\circledR}$, New Holland ${ }^{\circledR}$ e GreenStar ${ }^{\circledR}$, e reduziu de 0,85 para 0,83 para os dados obtidos com o monitor FieldStar ${ }^{\circledR}$, sendo esta a menor alteração devido à aplicação do filtro.

Considerando-se que alguns erros são função da dinâmica da relação entre máquina, monitor e cultura, espera-se que as características de cada erro se mantenham constantes para uma mesma máquina, com um mesmo monitor trabalhando na mesma cultura, facilitando o trabalho de filtragem dos dados. Evidentemente, o processo de filtragem não elimina a necessidade de correta calibração do sensor de produtividade e das rotinas de pré-colheita que favoreçam a boa qualidade da coleta de dados.

A rotina de filtragem proposta foi baseada no princípio da remoção de pontos problemáticos cujos problemas foram previamente caracterizados. Outras soluções poderiam ser aplicadas para aumentar a qualidade final dos mapas de produtividade. Ao lidar-se com pontos com problemas na leitura da umidade, ao invés de classifica-los como problemáticos e elimina-los do conjunto, poderia utilizar-se os pontos vizinhos, elaborar uma média e atribuir a média dos vizinhos ao ponto cuja leitura era inválida. Assim, evitaria-se a exclusão de pontos que possivelmente possuem informações valiosas. O mesmo tipo de solução poderia ser aplicado a pontos com produtividade nula, buscando-se aproveitar as outras informações contidas na linha que compõe o arquivo sem que a presença do ponto cause problemas de modificação das tendências. 
A calibração incorreta do tempo de espera gera um deslocamento dos pontos coletados na direção do deslocamento, e o sentido depende do valor do tempo de espera. Se superdimensionado, o deslocamento ocorre no sentido do movimento e se sub-dimensionado, o deslocamento ocorre em sentido contrário. Num processo mais elaborado, poder-se-ia calcular o deslocamento dos pontos a partir de medições na cabeceira dos talhões e, com esta informação associada ao índice de deslocamento, e equações trigonométricas, todos os pontos dos mapas poderiam ser realocados, em novo posicionamento que deveria ser mais próximo do local onde os pontos foram realmente coletados. Pontos com pequenos erros de posicionamento também poderiam ter sua posição alterada para sua alocação mais provável. Desvios de trajeto de colheita, sobreposição de passadas poderiam ser alteradas tendo por base uma linha imaginária que simularia o percurso da colhedora.

O processo de filtragem desenvolvido é de fácil aplicação aos conjuntos de dados, e o tempo de aplicação não sofre influência do número de pontos a serem trabalhados, sendo que o aumento da área de colheita e conseqüente aumento do número de pontos coletados aumentaria o esforço computacional. Em virtude da tecnologia atualmente disponível aos usuários comuns, levando em consideração a capacidade dos processadores utilizados em computadores domésticos, o esforço computacional é irrisório durante a aplicação do processo. Tratando-se de uma rotina integralmente aplicada em computadores, a criação de um programa baseado nas diretrizes do processo reduziria grandemente o tempo gasto na aplicação do filtro em cada arquivo que, atualmente é de aproximadamente 40 minutos. A automação da caracterização dos erros e sua retirada baseada nas características de cada erro pode ser considerado como a evolução natural do processo. 


\subsection{Conclusões}

O processo de filtragem desenvolvido é eficiente na eliminação de pontos problemáticos em pós-processamento de dados. A eliminação de pontos errôneos favorece o estabelecimento da dependência espacial e melhora o ajuste dos modelos aos dados. A intensidade da remoção de pontos é dependente do equipamento utilizado na obtenção dos dados.

Outras soluções poderiam ser aplicadas aos dados provenientes de monitores de produtividade, visando não a eliminação de pontos, mas a correção de erros e aproveitamento das demais informações contidas nas linhas que compõe o arquivo. 


\section{CONCLUSÕES GERAIS}

A qualidade da informação em agricultura de precisão é fator primordial para que o banco de dados formado dê sustentação ao processo de tomada de decisão. Nos arquivos de dados brutos analisados foram encontrados e caracterizados seis diferentes tipos de erros e dados discrepantes do conjunto. Os erros encontrados variaram conforme o monitor e a interação entre 0 monitor e a máquina, sendo que a presença ou ausência de cada um dos erros encontrados depende ainda da metodologia de coleta de informações. Alguns erros são característicos de cada equipamento, como por exemplo, a presença de pontos com produtividade de 9999,99 t.ha $^{-1}$ nos dados obtidos com o monitor RDS ${ }^{\circledR}$ Ceres 2 e a presença de pontos com distância nula entre si, erro muito comum nos dados obtidos com o monitor GreenStar ${ }^{\circledR}$.

Com base nas características individuais de cada erro presente em cada arquivo de dados brutos, a rotina de filtragem proposta é eficiente na retirada de erros e melhoria da qualidade da informação. A rotina atua diferentemente para cada arquivo de dados e a intensidade da remoção de pontos depende dos erros presentes nos dados brutos.

A rotina de filtragem é baseada na remoção de pontos considerados problemáticos. Quando da remodelação da rotina, pontos eliminados pela rotina atual poderiam ser aproveitados numa tentativa de estimar valores errôneos para pontos com problemas na umidade do grão e na produtividade. A realocação de pontos com problemas de posicionamento, seja por má calibração do tempo de espera ou por pequenos erros de posicionamento, constituem soluções que poderão ser implantadas futuramente. Sistemas de 
medição automática da largura efetiva de corte também são bastante desejáveis em monitores de produtividade, visto que a interpretação da largura de corte por parte do operado da máquina é fonte de erros em mapas de produtividade.

A remodelação da rotina de filtragem na forma de programa automatizado pode ser considerado como próximo passo com relação à remoção de erros e melhoria da qualidade da informação e agricultura de precisão. O programa deve ter condições de determinar a presença e as características dos erros presentes nos arquivos e elimina-los do conjunto de dados. A elaboração de um programa funcional reduzirá consideravelmente o tempo de aplicação do processo. 
ANEXOS 
Anexo A - Histogramas de distribuição de freqüência de ocorrência de produtividade antes e depois da aplicação do processo de filtragem.
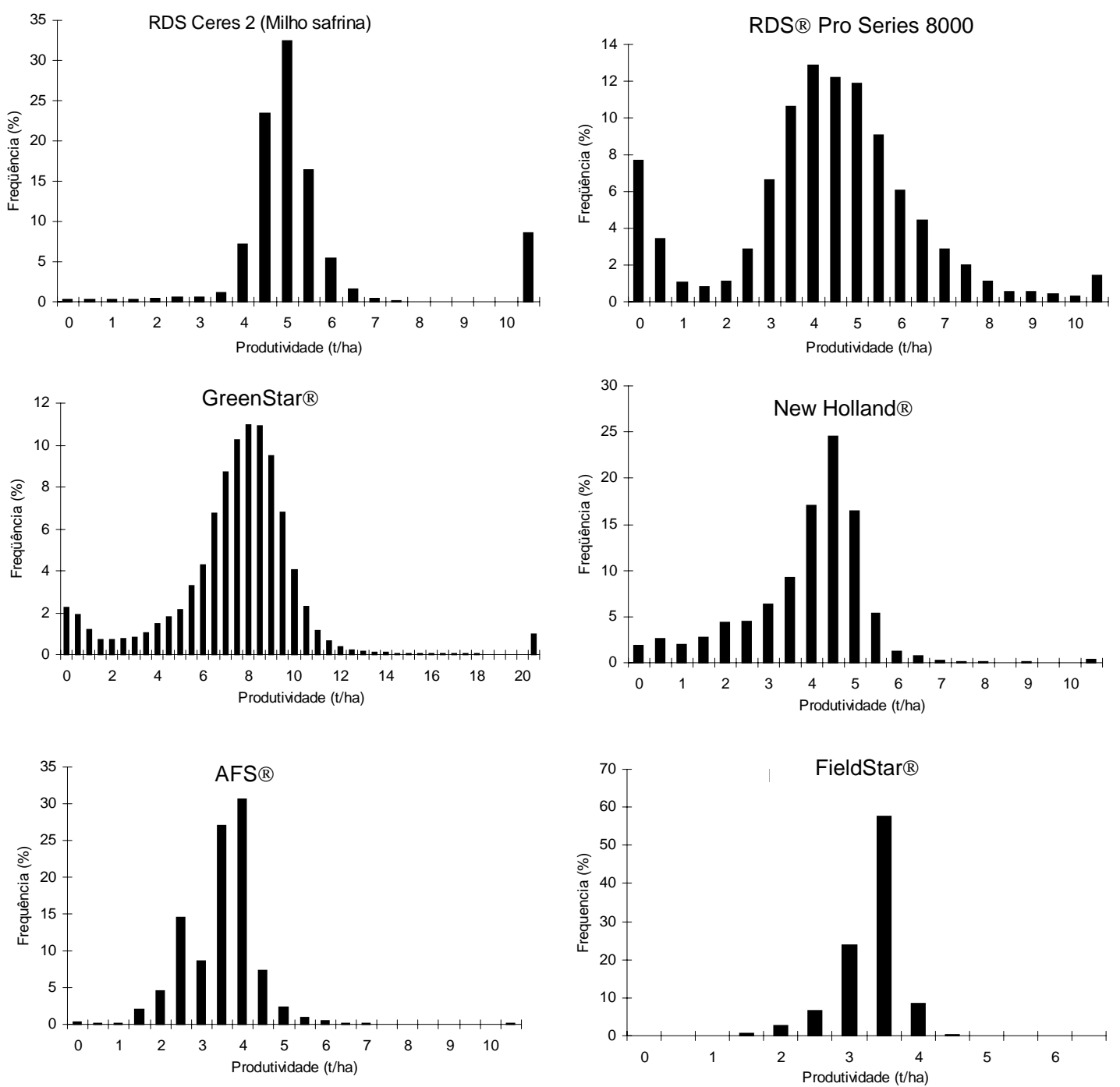

Figura 1 - Histogramas de distribuição da freqüência de ocorrência de produtividade para os arquivos analisados obtidos pelos diferentes monitores de produtividade antes do processo filtragem. 

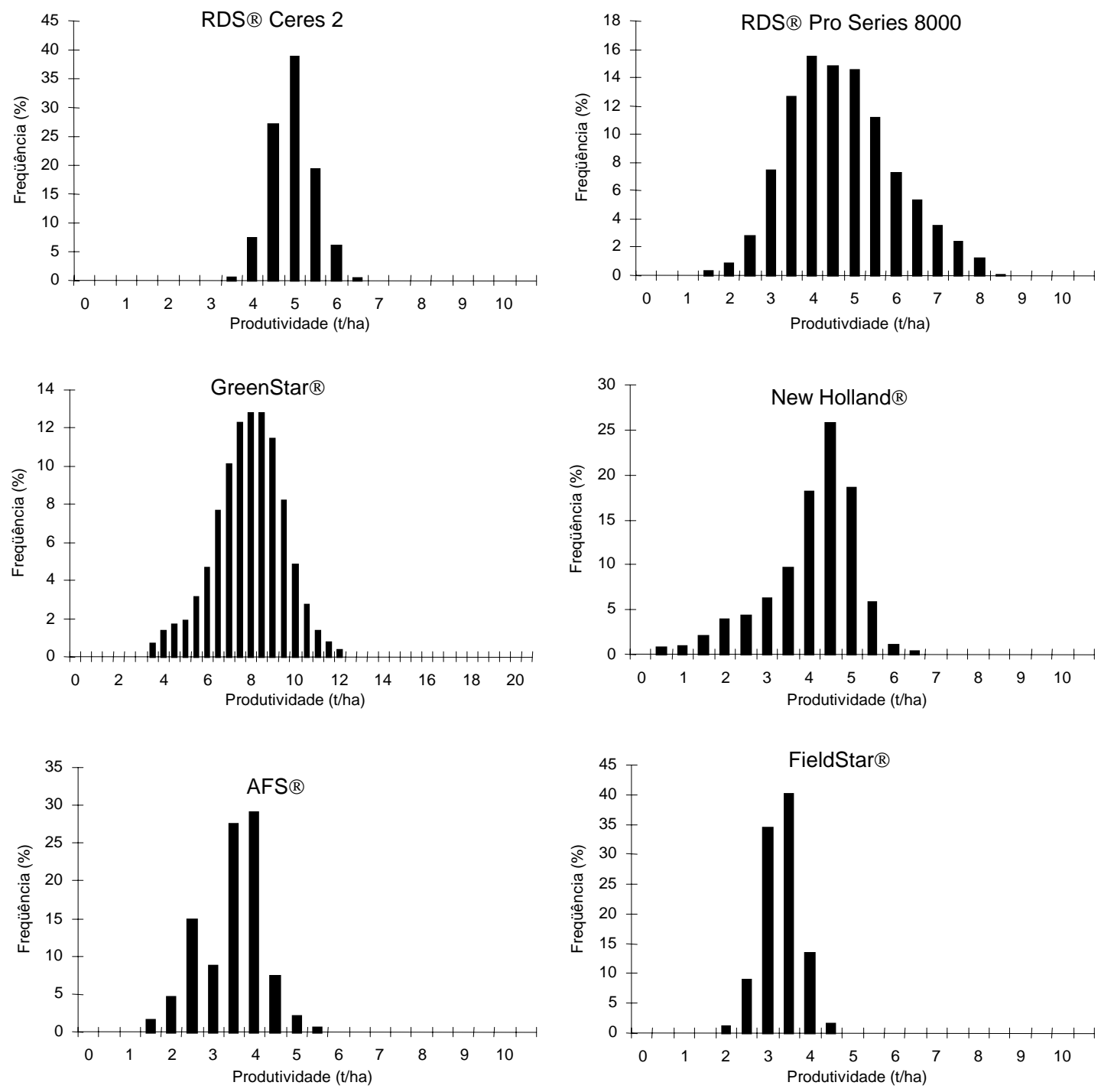

Figura 2 - Histogramas de distribuição de freqüência de ocorrência de dados de produtividade para os arquivos obtidos com os diferentes monitores de produtividade após o processo de filtragem. 
Anexo B - Semivariogramas e curvas de semivariância ajustados aos dados antes e depois do processo de filtragem
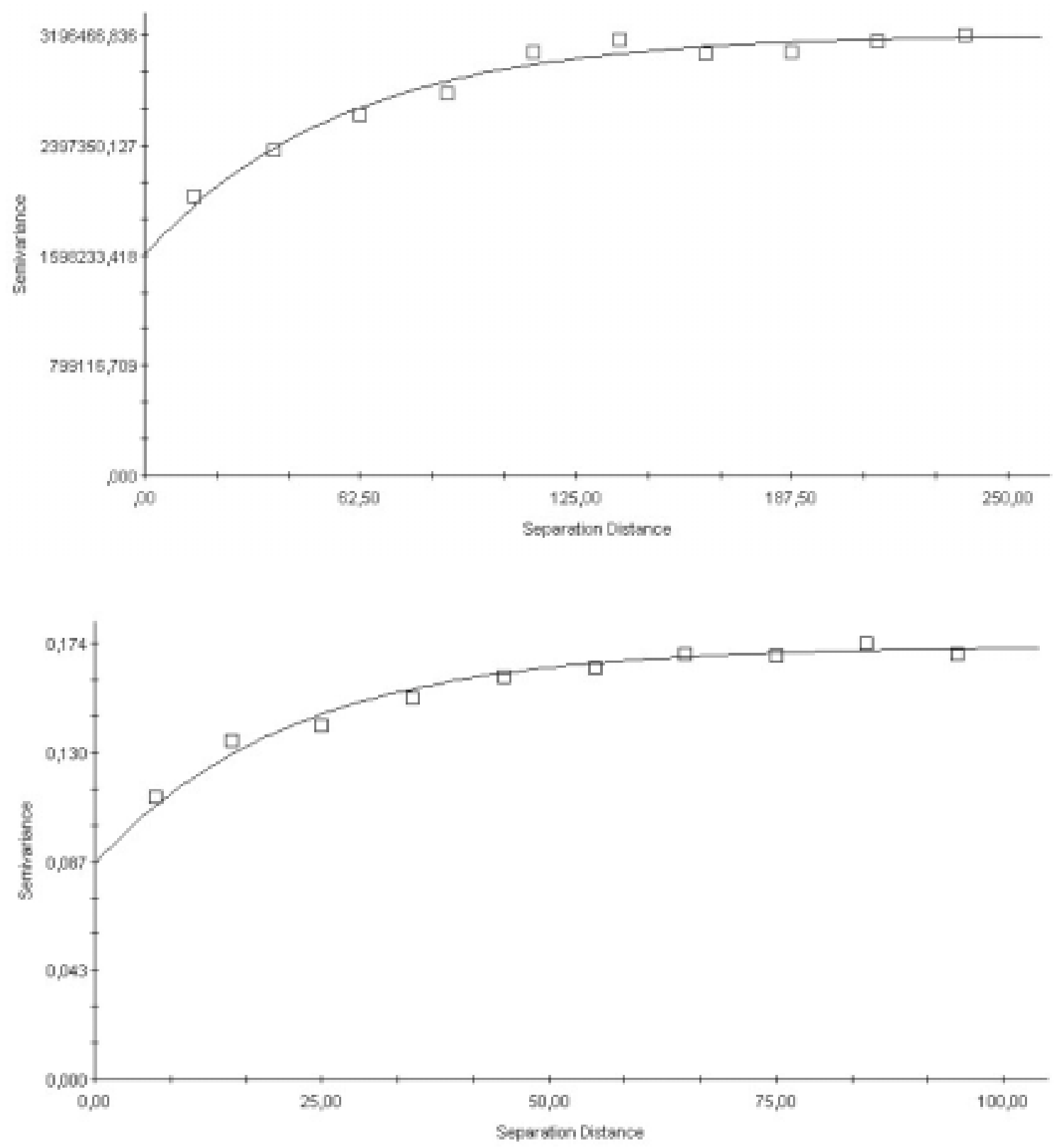

Figura 3 - Semivariogramas ajustados aos dados coletados com o monitor de produtividade $\operatorname{RDS}^{\circledR}$ Ceres 2 antes (acima) e depois do processo de filtragem (abaixo). 

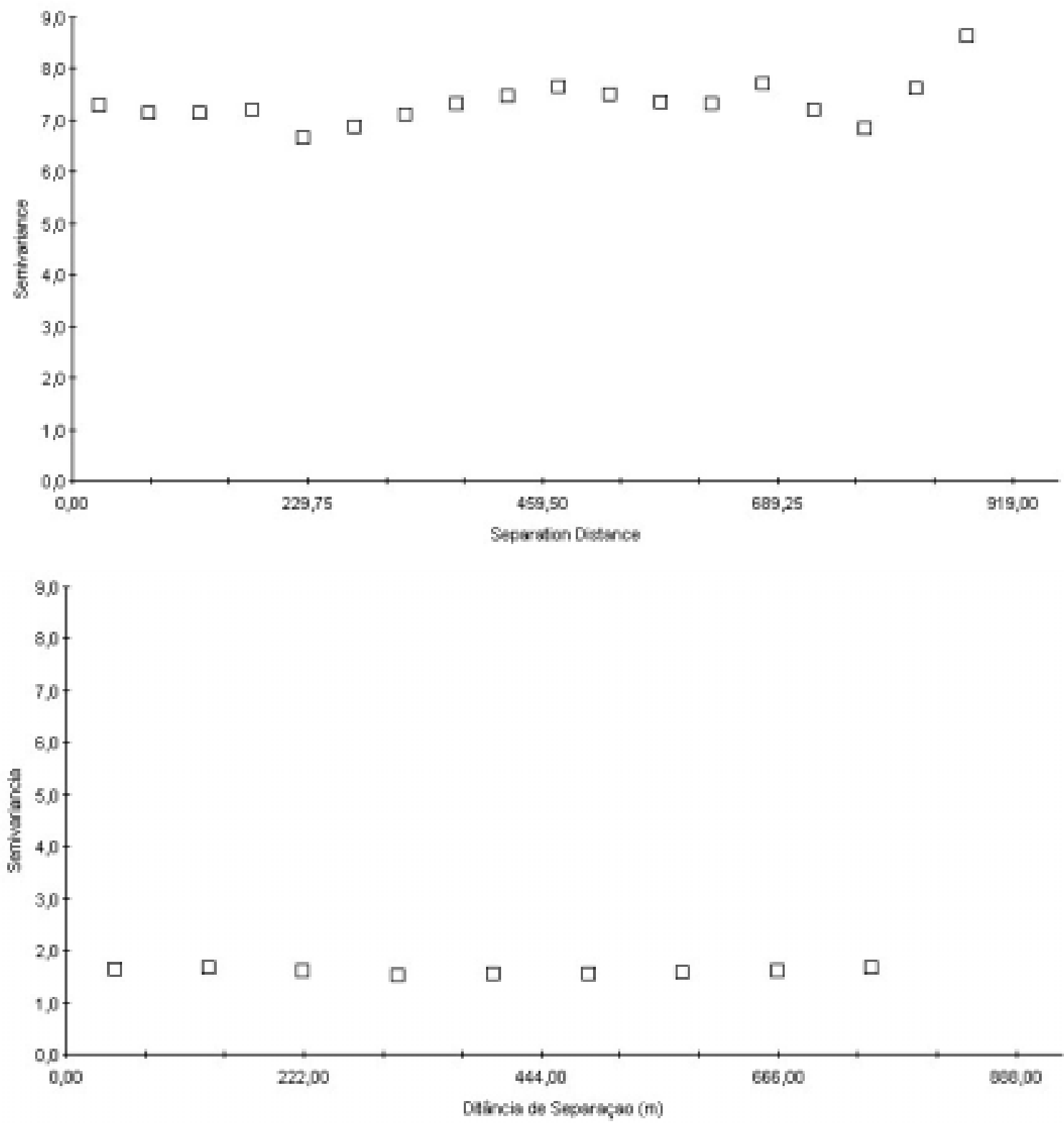

Figura 4 - Semivariogramas ajustados aos dados coletados com o monitor de produtividade RDS ${ }^{\circledR}$ Pro Series 8000 antes (acima) e depois do processo de filtragem (abaixo); nenhum modelo de dependência espacial foi ajustado aos dados. 

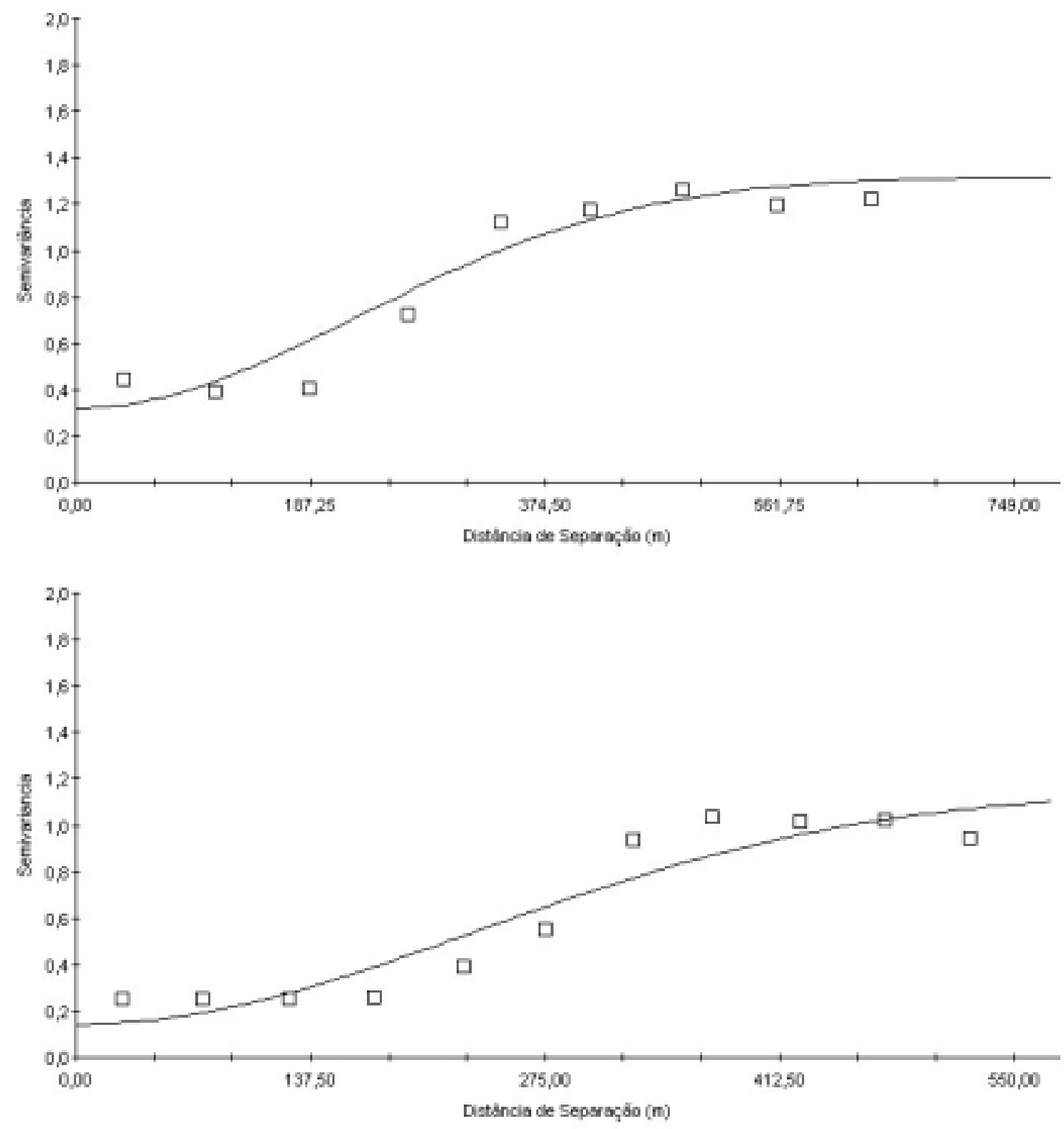

Figura 5 - Semivariogramas ajustados aos dados coletados com o monitor de produtividade $\mathrm{AFS}^{\circledR}$ antes (acima) e depois do processo de filtragem (abaixo). 

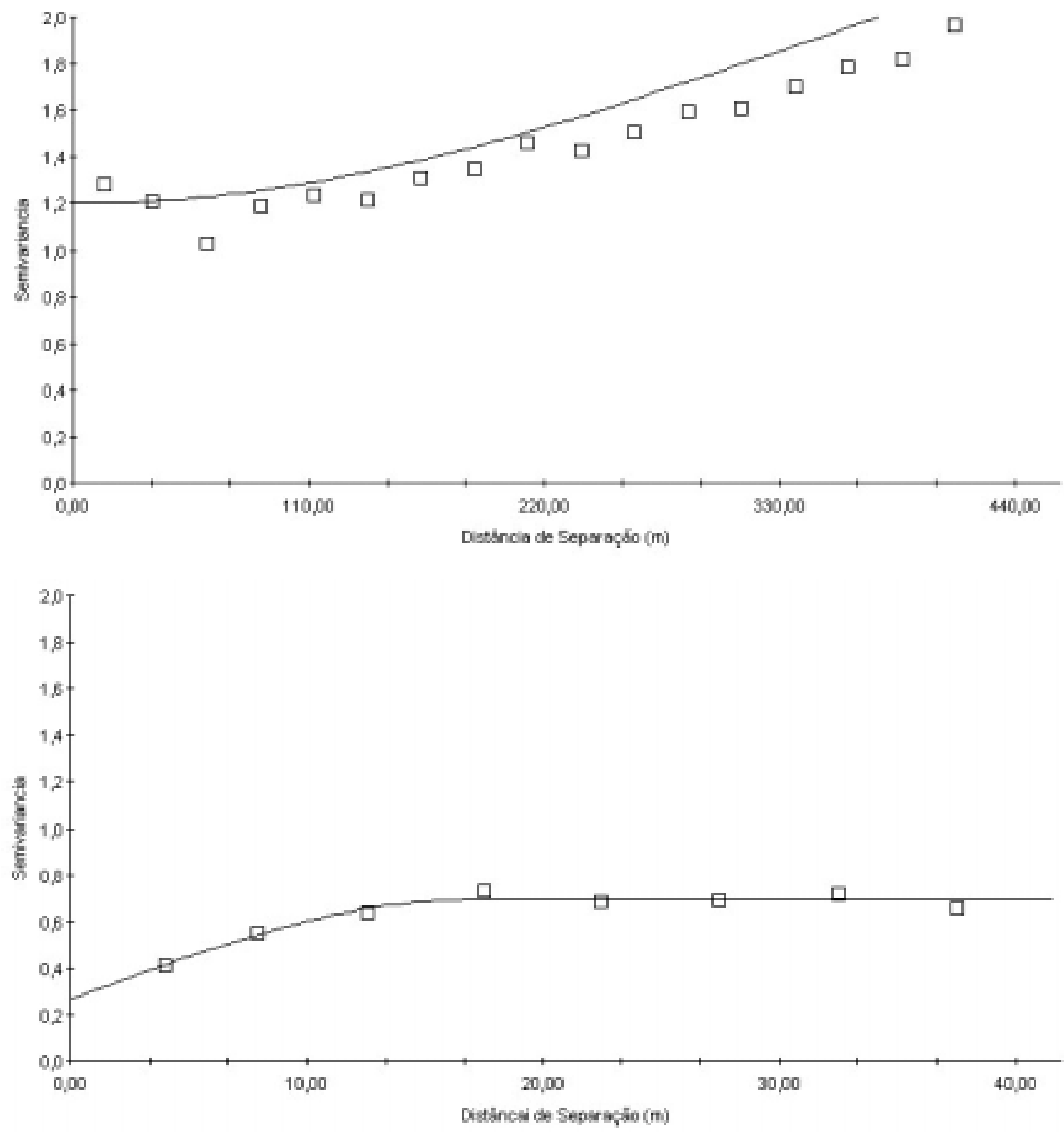

Figura 6 - Semivariogramas ajustados aos dados coletados com o monitor de produtividade New Holland $\AA$ antes (acima) e depois do processo de filtragem (abaixo). 

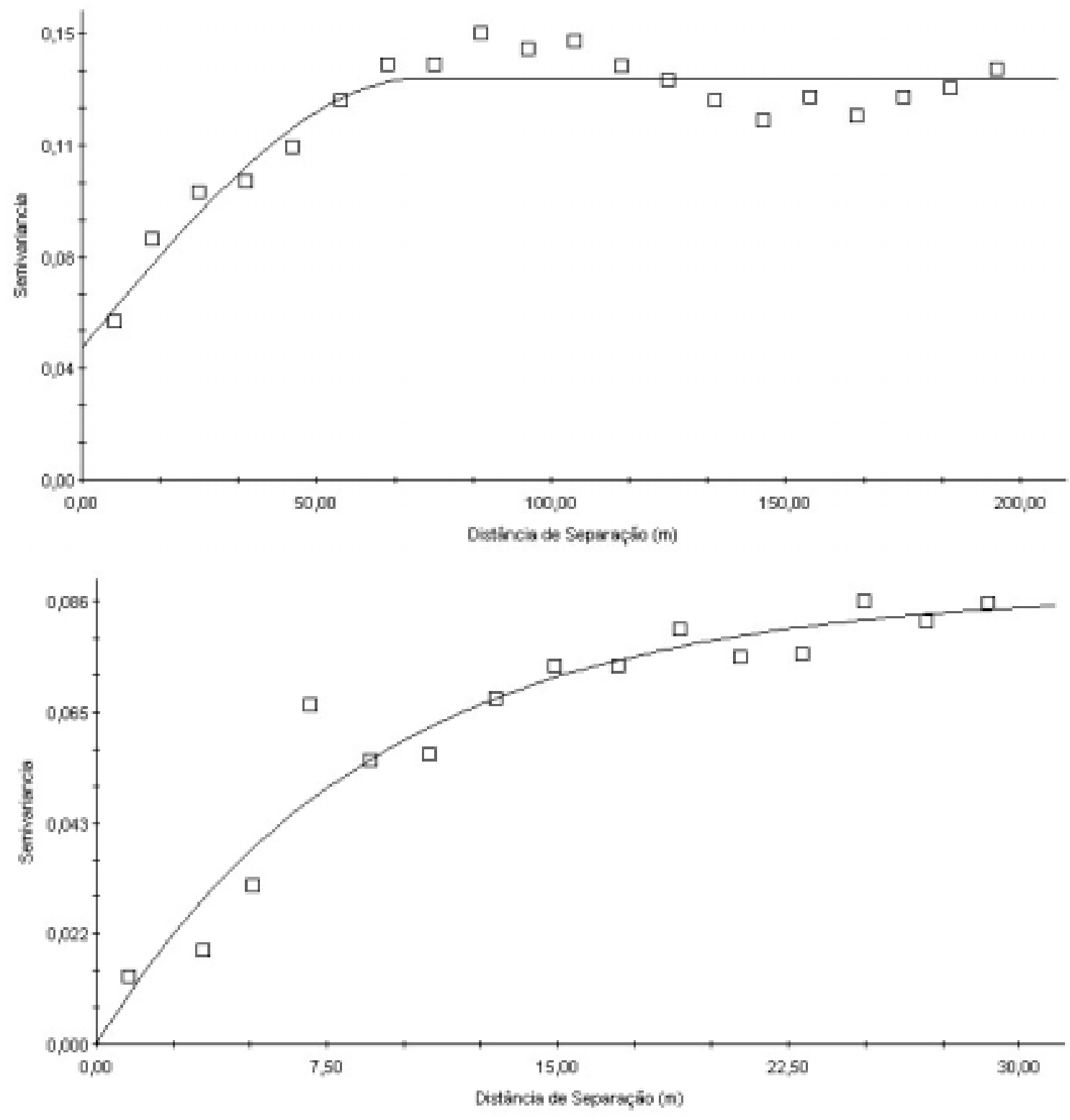

Figura 7 - Semivariogramas ajustados aos dados coletados com o monitor de produtividade FieldStar ${ }^{\circledR}$ antes (acima) e depois do processo de filtragem (abaixo). 

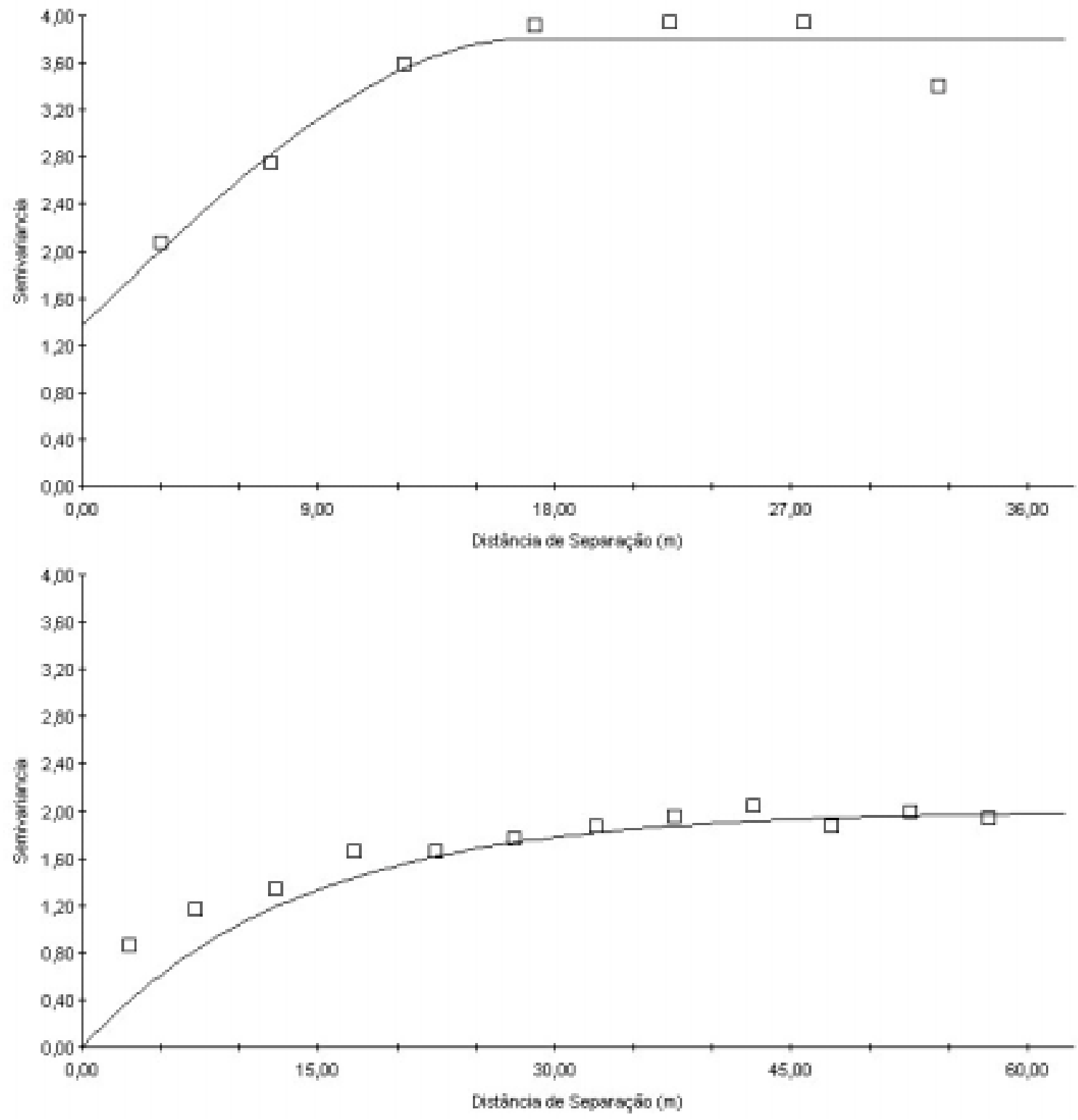

Figura 8 - Semivariogramas ajustados aos dados coletados com o monitor de produtividade GreenStar $^{\circledR}$ antes (acima) e depois do processo de filtragem (abaixo). 


\section{REFERÊNCIAS BIBLIOGRÁFICAS}

AUERNHAMMER, H.; DEMMEL, M.; MUHR, K.; ROTTMEIER, J.; WILD, K. Yield measurement on combine harvesters. In: ASAE WINTER MEETING, Chicago, 1993. Chicago: ASA;CSSA;SSSA, 1993. p.15. (ASAE paper, 011503)

BALASTREIRE, L.A. Estudo de caso, uma pesquisa brasileira em agricultura de precisão, In: SILVA, F.M.; BORGES, P.H.DE M. Mecanização e agricultura de precisão. Lavras: UFLA;SBEA, 1998. p. 302-231.

BIRREL, S.J.; SUDDUTH, K.A.; BORGELT, S.C. Comparison of sensors and techniques for crop yield mapping. Computers and Electronics in Agriculture, v.14, n.2, p.215-223, 1996.

BLACKMORE, B.S.; MARSHALL, C.J. Yield mapping; errors and algorithms. In: INTERNATIONAL CONFERENCE ON PRECISION AGRICULTURE, 3., Minneapolis,1996. Proceedings. Madison: ASA;CSSA;SSSA, 1996, p.403-415.

BLACKMORE, S.; MOORE, M. Remedial correction of yield map data. Precision Agriculture, v.1, n.1,p. 51-66, 1999. 
BORGELT, S.C. Sensing and measuring technologies for site specific management. In: SOIL SPECIFIC CROP MANAGEMENT, 1., Madison, 1993. Proceedings. Madison: ASA;CSSA;SSSA, 1993. p.141-157.

BURKS, T.F.; FULTON, J.P.; SHEARER, S.A.; SOBOLIK, C.J. Influence of dynamically inflow rates on clean grain elevator yield monitor accuracy. In: ASAE ANNUAL INTERNATIONAL MEETING, 1., Sacramento, 2001Sacramento: ASA;CSSA;SSSA , 2001. p.1182-1196. (ASAE Paper 011182)

CAMBARDELLA, C.A.; KARLEN, D.L. Spatial analysis of soil fertility parameters. Precision Agriculture, v.1, n.1, p. 5-14, 1999.

COLVIN, T.S.; ARSLAN, S. A review of yield reconstrution and sources of erros in yield maps (compact disc). In: INTERNATIONAL CONFERENCE ON PRECISION AGRICULTURE, 5., Madison, 2000. Proceedings. Madison: ASA, 2000c

DOEBELIN, E.O. Measurement systems: application and design. New York: D.M.Considini, 1966, 743p.

HANEKLAUS, S.; LILIENTHAL, H.; SCHNUG, E.; PANTEN,K.; HAVERECH, E. Routines for efficient yield mapping (Compact disc). In: INTERNATIONAL CONFERENCE ON PRECISION AGRICULTURE, 5., Madison, 2000. Proceedings. Madison: ASA, 2000.

HURN, J. GPS A guide to the next utility. 3. ed. Sunnyvale:Trimble Navigation Ltd., 1989. 76p. 
ISAAKS, E.H.; SRIVASTAVA; R.M. Applied geostatistics. Oxford: Oxford Universit Press, 1989. 561p.

JUERSCHIK, P.; GIEBEL, A. Processing of point data from combine harvesters for precision farming. In: EUROPEAN CONFERENCE ON PRECISION AGRICULTURE, 2., Denmark, 1997. Precision agriculture'99. Denmark: BIOS Scientific Publishers, 1999. v.1, p. 297-307.

LARK, R.M.; STAFFORD, J.V. Exploratory analysis of yield maps of combine crops, In: EUROPEAN CONFERENCE ON PRECISION AGRICULTURE, 1., Warwick, 1997. Precision agriculture'97. Warwick: BIOS Scientific Publishers, 1997. p. 887-894.

LARSCHEID, G.; BLACKMORE, B.S.; MOORE, M. Management decisions based on yield maps, In: EUROPEAN CONFERENCE ON PRECISION AGRICULTURE, 1., Warwick, 1997. Precision agriculture'97. Warwick: BIOS Scientific Publishers,1997. p. 895-902.

MAKEPEACE, R.J. Benefits and limitations of precision farming, In: CONFERENCE ON PESTS AND DISEASES, 1., Brighton, 1996. Proceedings. Brington: Brington University Express, 1996. p. 1235-1242, 1996.

MARCY, T.S.; THECKERY, D.L.; MACY, N.C. Yield monitoring experiences. In: ASAE WINTER MEETING,1., Atlanta, 1994. abstracts. Atlanta: ASAE, 1994. p.48.

MISSOTTEN, B.; STRUBBE, D.; DE BAERDEMAEKER, J. Accuracies of grain and straw yield maps. Agricultural Engineering. v.9, p.23-26, 1996. 
MOLIN, J.P. Geração interpretação de mapas de produtividade para agricultura de precisão, In: BORÉM,A.; GIÚDICE, M.P. del; QUIROZ, D.M. de; MANTOVANI, E.C.; FERREIRA, L.R.; VALLE, F.X.R. do; GOMIDE, R.L. Agricultura de precisão. Viçosa:Universidade Federal de Viçosa, 2000. p. 237-258.

MOLIN, J.P.; GIMENEZ, L.M. Desenvolvimento e um algoritmo para redução de erros em mapas de rendimento obtidos em agricultura de precisão (compact disc). In: CONGRESSO E MOSTRA DE AGROINFORMÁTICA, 1., Ponta Grossa, 2000. InfoAgro 2000. Ponta Grossa, 2000.

MOLIN, J.P.; CREMONINI, L.C.M.; MENEGATTI, L.A.A.; GIMENEZ, L.M. Acurácia de um monitor de produtividade com sensor de fluxo volumétrico (compact disc). In: CONGRESSO BRASILEIRO DE ENGENHARIA AGRícOLA, 29., Fortaleza, Ceará, 2000. CONBEA 2000. Fortaleza: SBEA, 2000.

MOLIN, J.P. Agricultura de precisão: o gerenciamento da variabilidade. Piracicaba, 2001. 81p.

MOORE, M. An investigation into the accuracy of yield maps and their subsequent use in crop management. Silsoe, 1998. p. 379. Thesis (Ph.D.) - Silsoe College.

MORGAN, M. ESS, D. The precision farming guide for agricultorists. Moline: Deere, 1997. $117 \mathrm{p}$. 
NOLAN, S.C.; HAVERLAND, G.W.; GODDARD, T.W.; GREEN, M.; PENNY, D.C.;HENRIKSEN, J.A.; LACHAPELLE, G. Building a yield map from georeferenced harvest measurement. In: INTERNATIONAL CONFERENCE ON PRECISION AGRICULTURE, 3., Minneapolis, 1996. Proceedings. Madison: ASA;CSSA;SSSA, 1996. p.885-892.

PECZE, Z.; NEMÉNYI, M.; KISS, E.; PETRÓCZKI, F. Investigation of the accuracy of the RDS yield mapping system. In: EUROPEAN CONFERENCE ON PRECISION AGRICULTURE, 2., Denmark, 1999. Programme abstracts (poster session 2) list of exhibitors. Denmark: BIOS Scientific Publishers, 1999. p.50.

REITZ, P., KUTZBACK, K.H. Investigations on a particular yield mapping system for combine harvesters. Computer and Electronics in Agriculture, v. 14, n. 2/3, p. 137-150, 1996.

STTOT, B.L., BORGELT, S.C., SUDDUTH, K.A. Yield determination using an instrumented Class combine. In: ASAE WINTER MEETING, Chicago, 1993. Chicago: ASA;CSSA;SSSA, 1993. p. 1507-1521. (ASAE Paper 93-1507)

TAYLOR, R.K.; KASTENS, D.L. ; KASTENS, T.L. Creating yield maps from yield monitor data using multi-purpose grid mapping (mpgm) (compact disc). In: INTERNATIONAL CONFERENCE ON PRECISION AGRICULTURE, 5., Madison, 2000. Proceedings. Madison: ASA, 2000.

THYLÉN, L.; JURSCHIK, P.; MURPHY, D.L.P. Improving the quality of yield data, In: EUROPEAN CONFERENCE ON PRECISION AGRICULTURE, 1., Warwick, 1997. Precision agriculture'97, Warwick: BIOS Scientific Publishers, 1997. v.1, p. 743-750. 
TUKEY, J.W. Exploratory data analysis. Reading: Adsson-Wesley, 1977. 3v.

VANSICHEN R.; DE BAERDEMAEKER, J. Measuring the actual cutting width of a combine by means of an ultrasonic sensor. TRENDS IN AGRICULtURAL ENGINEERING, 1., Prague, 1992. Proceedings. Prague, 1992. p.15-18.

WOLLENHAUPT,N.C.; MULLA, D.J.; CRAWFORD, C.A.G.; PIERCE, F.J.; SADLER, E.J. Soil sampling and interpolation techniques for mapping spatial variability of soil properties. In: WOLLENHAUPT,N.C.; MULLA, D.J.; CRAWFORD, C.A.G.; PIERCE, F.J. The state of Site specific management for agriculture. Madison: American Society of Agronomy, 1997. p.19-53. 